NBER WORKING PAPER SERIES

\title{
GENERAL EQUILIBRIUM EFFECTS OF (IMPROVING) PUBLIC EMPLOYMENT PROGRAMS: EXPERIMENTAL EVIDENCE FROM INDIA
}

\author{
Karthik Muralidharan \\ Paul Niehaus \\ Sandip Sukhtankar \\ Working Paper 23838 \\ http://www.nber.org/papers/w23838 \\ NATIONAL BUREAU OF ECONOMIC RESEARCH \\ 1050 Massachusetts Avenue \\ Cambridge, MA 02138 \\ September 2017, Revised September 2021
}

We thank the editor Dave Donaldson and three anonymous referees, David Atkin, Abhijit Banerjee, Prashant Bharadwaj, Gordon Dahl, Taryn Dinkelman, Roger Gordon, Gordon Hanson, Clement Imbert, Supreet Kaur, Dan Keniston, Atila Lindner, Aprajit Mahajan, Edward Miguel, Ben Moll, Dilip Mookherjee, Imran Rasul, Mark Rosenzweig and participants in various seminars for comments and suggestions. We are grateful to officials of the Government of Andhra Pradesh, including Reddy Subrahmanyam, Koppula Raju, Shamsher Singh Rawat, Raghunandan Rao, G Vijaya Laxmi, AVV Prasad, Kuberan Selvaraj, Sanju, Kalyan Rao, and Madhavi Rani; as well as Gulzar Natarajan for their continuous support of the Andhra Pradesh Smartcard Study. We are also grateful to officials of the Unique Identification Authority of India (UIDAI) including Nandan Nilekani, Ram Sevak Sharma, and R Srikar for their support. We thank Tata Consultancy Services (TCS) and Ravi Marri, Ramanna, and Shubra Dixit for their help in providing us with administrative data. This paper would not have been possible without the continuous efforts and inputs of the J-PAL/UCSD project team including Kshitij Batra, Thomas Brailey, Soala Ekine, Prathap Kasina, Michael Kaiser, Frances Lu, Piali Mukhopadhyay, Raghu Kishore Nekanti, Matt Pecenco, Sabareesh Ramachandran, Surili Sheth, Pratibha Shrestha, and Kartik Srivastava. Finally, we thank the Omidyar Network (especially Jayant Sinha, CV Madhukar, Surya Mantha, and Sonny Bardhan) and the Bill and Melinda Gates Foundation (especially Dan Radcliffe, and Seth Garz) for the financial support that made this study possible. The views expressed herein are those of the authors and do not necessarily reflect the views of the National Bureau of Economic Research.

NBER working papers are circulated for discussion and comment purposes. They have not been peer-reviewed or been subject to the review by the NBER Board of Directors that accompanies official NBER publications.

(C) 2017 by Karthik Muralidharan, Paul Niehaus, and Sandip Sukhtankar. All rights reserved. Short sections of text, not to exceed two paragraphs, may be quoted without explicit permission provided that full credit, including (C) notice, is given to the source. 
General Equilibrium Effects of (Improving) Public Employment Programs: Experimental

Evidence from India

Karthik Muralidharan, Paul Niehaus, and Sandip Sukhtankar

NBER Working Paper No. 23838

September 2017, Revised September 2021

JEL No. D50,D73,H53,J38,J43,O18

\begin{abstract}
Public employment programs may affect poverty both directly through the income they provide and indirectly through general-equilibrium effects. We estimate both effects, exploiting a reform that improved the implementation of India's National Rural Employment Guarantee Scheme (NREGS) and whose rollout was randomized at a large (sub-district) scale. The reform raised beneficiary households' earnings by $14 \%$, and reduced poverty by $26 \%$. Importantly, $86 \%$ of income gains came from non-program earnings, driven by higher private-sector (real) wages and employment. This pattern appears to reflect imperfectly competitive labor markets more than productivity gains: worker's reservation wages increased, land returns fell, and employment gains were higher in villages with more concentrated landholdings. Non-agricultural enterprise counts and employment grew rapidly despite higher wages, consistent with a role for local demand in structural transformation. These results suggest that public employment programs can effectively reduce poverty in developing countries, and may also improve economic efficiency.

Karthik Muralidharan

Department of Economics, 0508

University of California, San Diego

9500 Gilman Drive

La Jolla, CA 92093-0508

and NBER

kamurali@ucsd.edu

Paul Niehaus

Department of Economics

University of California, San Diego

9500 Gilman Drive \#0508

La Jolla, CA 92093

and NBER

pniehaus@ucsd.edu

Sandip Sukhtankar

Department of Economics

University of Virginia

Charlottesville, VA 22904

srs8yk@ virginia.edu
\end{abstract}


Public employment programs, in which the government provides jobs to those who seek them, are among the most common anti-poverty programs in developing countries. Economic rationales for such programs include self-targeting through work requirements, public asset creation, and enforcing wage floors in informal labor markets by making the government an employer of last resort.1 The world's largest such program is the National Rural Employment Guarantee Scheme (NREGS) in India, with over 600 million rural residents eligible to participate and a fiscal allocation of $0.5 \%$ of India's GDP.

Whether and to what extent such a program raises incomes and reduces poverty is a first-order policy question. It is also a subtle one, as the gains participants obtain directly from program earnings themselves (which are relatively easy to observe) may be attenuated or amplified by partial- and general-equilibrium (GE) effects. For instance, gross program earnings may overstate net income gains for the poor to the extent that they substitute out of private employment (Bertrand et al., 2021), or understate them to the extent that market wages increase, with the magnitude of these effects depending in turn on labor market structure. Answering this question requires credible identification of impacts at scales large enough to move markets, accounting for the spatial spillovers this may involve, and measuring income from various sources comprehensively. For the NREGS (and for public employment schemes in general) this has proven challenging. ${ }^{2}$

In this paper we address these challenges by combining experimental variation in NREGS implementation quality, units of randomization large enough to capture labor-market GE effects, units of observation geocoded finely enough to adjust estimates for spatial spillovers, and a wide range of both survey and census data. Specifically, we worked with the Government of the Indian state of (erstwhile) Andhra Pradesh (AP) to randomize the order in which 157 sub-districts (mandals) with an average population of 62,500 each introduced a new system (biometric "Smartcards") for making payments in NREGS during 2010-2012. In prior work, we show that Smartcards substantially improved NREGS performance on several dimensions: it reduced leakage of funds, increased program earnings, reduced pay-

\footnotetext{
${ }^{1}$ Workfare programs may also be politically more palatable to taxpayers than unconditional "doles." Such programs have a long history, with recorded instances from as early as the 18th century in India, the public works constructed in the US by the WPA during the Depression-era in the 1930s, and more modern programs across Sub-Saharan Africa, Latin America, and Asia (Subbarao et al., 2013).

${ }^{2}$ With respect to the NREGS there have been four main issues. First, experimental variation has not been available, with the consequence that studies often reach opposing conclusions depending on the data and identification strategy used (see Sukhtankar (2017)). Second, many data sources do not permit geolocation of affected households at levels finer than the identifying variation (typically the district), which is needed to identify spatial spillovers. Third, a key data source (the National Sample Survey) does not collect data on income, and did not collect representative district-level data on consumption (used for poverty estimates) during NREGS rollout. Finally, NREGS implementation quality varied considerably across time and space, making it difficult even to define in precise terms the intervention whose effects are measured.
} 
ment delays and the time required to collect payments, and increased real and perceived access to work, without changing fiscal outlays on the program (Muralidharan et al. (2016), henceforth MNS).

In short, Smartcards brought NREGS implementation closer in specific, measured ways to what its architects intended. This paper studies the downstream effects of a betterimplemented NREGS on income, poverty, and labor markets. These effects are both intrinsically important, and also informative about - though not necessarily the same as - the effects of rolling out NREGS itself (a comparison we explore further in the conclusion) $!^{3}$

We study these effects using data from an original survey of $\sim 5,000$ households, sampled to be representative of the $49.5 \%$ of rural households registered for NREGS. These surveys were conducted two years after the randomized rollout of the Smartcard program, before the control group was treated. We have detailed data on income for the full year preceding the survey, and on wages and employment for the month of June. To study impacts on the full population, we supplement these data with three distinct censuses - of households, non-agricultural employment and enterprise, and livestock - conducted by the government independently of our efforts and at around the same time. We also draw on the National Sample Survey (NSS) for consumer price information, and administrative data on land use and irrigation. Each data source has limitations, but collectively they allow us to paint a reasonably comprehensive picture of the reform's economic consequences..$^{4}$

We find, first and foremost, that improving NREGS implementation substantially increased real incomes of the rural poor. Mean earnings among NREGS-registered households increased by $13.9 \%$, leading to a $25.8 \%$ ( 7.4 percentage points) reduction in an income-based measure of poverty, while consumer goods prices did not change significantly. Strikingly these income gains came primarily from sources other than the NREGS. Program earnings accounted for only $14 \%$ of income gains, whereas the majority (80\%) of the total income increase came from private labor-market earnings.

This increase in labor market earnings in turn reflects the fact that both market wages and employment rose in tandem. Wages rose substantially, by $10.1 \%$ in treated areas during June, consistent with the expectation that competitive pressure from the NREGS would influence

\footnotetext{
${ }^{3}$ The centrality of implementation quality in evaluating the effects of NREGS is well recognized. For instance, Imbert and Papp (2015) focus their analysis on the "star" states that implemented the program well during the initial rollout. Our paper follows in this same tradition.

${ }^{4}$ Two limitations are especially noteworthy. First, our survey measured wages and employment in June, because this is near the peak season of NREGS activity and hence most relevant for studying the impacts of Smartcards on NREGS implementation. However, this limits our ability to study the transmission of wage and employment effects to the rest of the year. Second, our survey sampling frame of households registered for the NREGS (jobcard holders) likely excludes large landholders who may have been made worse off by the reform. We therefore study distributional effects using both survey and census data (see Section 3.3).
} 
private-sector wages. Yet despite higher wages, we see an increase, not a decrease, in market employment among NREGS-registered households, which rose by 20\% (1.4 days/month), while days self-employed or not working fell by $13 \%$ (2.4 days/month). For each of these outcomes we document significant spatial spillover effects which independently validate the thesis that the reform impacted private labor markets - and which would lead us to substantially understate total effects if not accounted for. These results are internally consistent in the sense that the wage and employment gains we observe in June would, if persistent through the year, explain the increases in annual labor earnings.

Independent census data corroborate the finding that the reform reduced poverty, and also had large economic effects on the overall population. In a census of rural households, the proportion in the lowest income bracket fell by $3.4 \%$ (2.8 percentage points). We also document substantial increases in non-agricultural employment, paralleling the employment gains in our survey data. Employment in non-agricultural establishments in the Economic Census of firms rose $34 \%$ (11 percentage points). The number of these establishments increased by $23 \%$ in parallel, with increases concentrated among small owner-operated enterprises. To put this magnitude in perspective, this employment increase within 3 years of the reform was $11 \%$ of the working-age population; whereas the share of the Indian workforce engaged in non-agricultural employment increased by $8 \%$ in the entire preceding decade (2000-10).

We analyze the distributional consequences of the reform by combining census and survey data. Our calculations suggest that the income gains in our survey of NREGS-registered households fully account for the gains we see in the census of all households. This suggests that poverty reductions were concentrated among NREGS-registered households, as one might expect given they tend to be relatively more dependent on labor as opposed to land income. While we do not directly observe the profits of large landholders, we find that farm earnings per acre fell by $18 \%$ and land prices fell by an insignificant $6 \%$ among those NREGS-registered households that did own some land, which is consistent with the idea that higher labor costs reduced the returns to land ownership. Combining estimated treatment effects on wage income and land profits with census data on labor and land endowments, we estimate that net incomes increased for the bottom $92.5 \%$ of households by landholdings, and that net income decreased only for large landowners holding over 7 acres of land.

The fact that both wages and employment increased is central to the large income gains we estimate: wage gains were not offset by reduced employment, but instead were amplified by increased employment. We consider three broad sets of (non mutually exclusive) mechanisms for the increase in wages and employment: (1) an increase in labor productivity; (2) an inward shift in labor supply in the context of imperfectly competitive labor markets (e.g. oligopsony); (3) increases in aggregate demand for locally-produced goods and services. To 
help interpret the relative importance of these channels, we combine estimated treatment effects with a canonical theoretical model of production, labor supply, and demand.

Our calculations suggest that direct increases in rural labor productivity through augmentation of either physical or human capital from a better-implemented NREGS were likely second order. This interpretation is corroborated by our finding negative treatment effects on land profits and prices (which should be weakly increasing in productivity).

In contrast, we find clear evidence that labor supply to private sector jobs shifted inwards. Reservation wages increased significantly in treated areas, suggesting that an improved NREGS increased workers' bargaining power by enhancing outside options. Moreover, changes in market employment covary systematically with proxies for employer market power. Specifically, treatment led to significantly greater increases in private-market employment in villages with greater land concentration, as measured by a normalized HerfindahlHirschman index (HHI). While this index likely does not capture all aspects of employer market power, we estimate that it can explain $23 \%$ of the overall increase in market employment. We estimate an upper bound on the markdown of wages relative to marginal product of $25 \%$. This is within, but at the higher end of, the range of estimates in a global evidence review (Sokolova and Sorensen, 2021), suggesting that employers may have considerable market power in this setting.

Finally, we find several pieces of evidence suggesting meaningful increases in local demand from the increased income. First, savings increased by only $3 \%$ of the estimated income gain. Second, both borrowing and asset holdings of NREGS beneficiaries increased in treated areas. Together, these two facts suggest that most of the income gains were either consumed or used to acquire assets (but not saved), which would boost local demand 5 Finally, the large increase in the number of non-agricultural firms, and in employment in these firms suggest that the net benefits of increased demand exceeded the cost of higher wages.

Our first contribution is to the literature and policy debate on the impact of public works programs on labor markets, incomes and poverty (Imbert and Papp, 2015; Beegle et al., 2017; Sukhtankar, 2017; Bertrand et al., 2021). We confirm some prior findings, like the increase in market wages (Imbert and Papp, 2015; Berg et al., 2018), while providing estimates that account for spatial spillovers - in some cases consequentially. We also report a number of new results, including gains in income and reductions in poverty, balance sheet effects, reductions in land returns, and positive effects on private sector employment in two independent data sources. We show in Section 3.4 that this latter result is critical to reconciling our estimates

\footnotetext{
${ }^{5}$ Unlike the NSS, we focused on measuring income rather than consumption, and our measures of consumption are quite rudimentary. As a result, estimated effects on consumption are very imprecise with a $95 \%$ CI of the marginal propensity to consume the additional income of $[-92 \%,+100 \%]$. We therefore infer increases in local demand from the much more precisely estimated (small) treatment effects on savings.
} 
quantitatively with those in Imbert and Papp (2015). Taken together, our results suggest that public employment programs can both reduce poverty and enhance economic efficiency.

Second, we contribute to the literature on rural labor markets in developing countries (Jayachandran, 2006; Kaur, 2019). The employment gains we document, and particularly the mediating role of concentrated landholdings, add to the growing body of evidence of employer market power in a wide range of markets ${ }^{6}$ Our employment results are also broadly consistent with evidence pointing to the absence of large negative employment effects of minimum wages both in developing countries (e.g. Dinkelman and Ranchhod (2012)) and elsewhere 7 Further, our finding large gains in non-agricultural employment adds experimental support to the idea posited by Magruder (2013), Emerick (2018) and Santangelo (2019) (among others) that positive earnings shocks in more "traditional" sectors can drive structural transformation (through boosting aggregate demand), even while raising wages.

Third, our results highlight the influence public options can exert on private markets even when they themselves capture only modest market shares. Critics have argued that the NREGS could not have meaningfully affected market wages because NREGS work constitutes only a small share of rural employment (Bhalla, 2013). A similar premise holds in our data: only $7 \%$ of income earned by our control group came from the NREGS. Yet $32 \%$ of households actively participated in the NREGS at some point in 2011-12 (in NSS data), and the reform sharply increased their reservation wages. This underscores that the NREGS's impact depends not only on its "market share" but also its credibility as an outside option. Improving this option can in turn raise wages in the private sector, as suggested by Dreze and Sen (1991) and Basu et al. (2009) 8

Fourth, and related, our results highlight the importance of accounting for general equilibrium effects in program evaluation (Acemoglu, 2010). Ignoring these effects (say by randomizing program access at the individual level) would have led to us to sharply underestimate impacts on rural wages and poverty. Even analyzing our own data while ignoring market spillovers to control areas would meaningfully understate impacts on wages and employment. Viewed positively, our study demonstrates the feasibility of conducting experiments with units of randomization large enough to capture general equilibrium effects (Muralidharan and Niehaus, 2017; Cunha et al., 2019; Egger et al., 2020).

Fifth, our results highlight program implementation quality in developing countries as a

\footnotetext{
${ }^{6}$ For example, online labor markets (Dube et al. 2020$)$ and migrant labor markets (Naidu et al. 2016 ).

${ }^{7}$ See Card and Krueger (1994), Cengiz et al. (2019) and Harasztosi and Lindner (2019), among others.

${ }^{8}$ In a related vein, Beaudry et al. (2012) show that changes in city-level industrial composition affect average wages by 3-4 times more than would be expected based on a simple accounting approach, likely because they affect wage bargaining, and Clemens and Gottlieb (2017) show that Medicare pricing affects private sector health care prices in the US, despite comprising less than a third of the market.
} 
first order issue in and of itself. It is striking that the estimated effects on market wages of improving NREGS implementation are about as large as the effects of the initial rollout itself (Imbert and Papp, 2015), and much larger than the effects of simply increasing official wages without reforming implementation (which Niehaus and Sukhtankar (2013b) find had no impact on workers' earnings). This suggests that more generally in settings with high corruption and inefficiency it may be more cost-effective to invest in better implementation of a program than to simply increase program budgets.

\section{Context \& Intervention}

\subsection{The NREGS}

The NREGS is the world's largest public employment scheme, entitling any household living in rural India (i.e. 11\% of the world's population) to up to 100 days per year of guaranteed paid employment. It is one of India's flagship social protection programs, and the Indian government spent roughly $6.8 \%$ of its budget $(\sim 0.5 \%$ of GDP) on it in $2011-12.9$ Coverage is broad: $\sim 50 \%$ of rural households in Andhra Pradesh were registered for the program in 2011-12, meaning that they had a jobcard and were therefore legally entitled to request work at any time. NREGS jobs involve manual labor compensated at statutory piece rates, and are meant to induce self-targeting. NREGS projects typically involve labor-intensive public infrastructure improvements such as minor irrigation or water conservation works, minor road construction, and land clearance for cultivation.

As of 2010, NREGS implementation suffered from several known issues. Rationing was common even though de jure jobs should be available on demand, with access to work constrained both by budgetary allocations and by local capacity to implement projects (Dutta et al., 2012). Corruption was widespread, and occurred both through over-invoicing the government to reimburse wages for work not actually done and paying workers less than their due, among other methods (Niehaus and Sukhtankar, 2013a b). Finally, the payment process was slow and unreliable: payments were time-consuming to collect, and were often unpredictably delayed for over a month beyond the 14-day period prescribed by law (Khera, 2011; Banerjee et al., 2020).

\footnotetext{
${ }^{9}$ NREGS spending source: https://www.indiabudget.gov.in/budget2011-2012/ub2011-12/bag/ bag5.pdf, outlays source: https://www.indiabudget.gov.in/budget2011-2012/ub2011-12/bag/bag4 . pdf, both accessed October 1, 2019.
} 


\section{$1.2 \quad$ Smartcards}

To help address these issues, the Department of Rural Development of the Government of AP introduced a new payments system, which we refer to as "Smartcards" for short. This involved two major changes. First, the flow of funds shifted in most cases from governmentrun post offices to banks, who worked with local partners (called banking correspondents) to make last-mile cash payments in the village itself. Second, the protocol for authenticating when collecting payments changed from one based on paper documents and ink stamps to one based on biometric authentication using Smartcards.

The Smartcards reform improved NREGS implementation quality on several dimensions, as we show in MNS. Payments in treated mandals arrived 29\% faster, with arrival dates $39 \%$ less varied, and took $20 \%$ less time to collect. Households earned more working on NREGS (24\%), and there was a substantial 12.7 percentage point ( $\sim 41 \%)$ reduction in leakage (defined as the difference between fiscal outlays and beneficiary receipts). Program access also improved: both perceived access and actual participation in NREGS increased (17\%). These gains were widely distributed; we find little evidence of heterogeneous impacts, and treatment distributions first order stochastically dominate control distributions for all outcomes on which there was a significant mean impact. Fiscal outlays, on the other hand, were unchanged. Overall, Smartcards substantially improved NREGS implementation in directly measured ways, and made it a more credible option for the rural poor. Reflecting this, users were strongly in favor of Smartcards, with $90 \%$ of households preferring it to the status quo and only $3 \%$ opposed.

Given that Smartcards brought the effective presence of NREGS closer to the intentions of its framers, one might in principle think of them as an instrumental variable for a measure of "effective NREGS." In practice defining such a measure is difficult since implementation quality is multi-dimensional, spanning job access and availability, job receipt, wages received net of corruption, speed and reliability of payments, and so on. Past work has typically used administrative records on the number of days of employment provided as a proxy for implementation quality, but this measure may be overstated due to corruption, and also reflect labor market conditions unrelated to implementation quality. ${ }_{10}^{10}$ One alternative metric which may better quantify the value of changes in NREGS implementation as assessed by workers themselves is the change in their reservation wages, i.e. the amount an employer would have to pay to attract a worker away from the NREGS (or simply not working). Below we estimate that Smartcards increased reservation wages by Rs. 6.9 per day on average (7.1\%

\footnotetext{
${ }^{10}$ For instance, reported employment is higher during drought years Santangelo, 2019). In our setting we see no impact on this metric (Table A.1) despite seeing large impacts on actual participation and on-theground performance.
} 
of the control mean); one might interpret this as the magnitude of the "first stage" effect.

In addition to NREGS, Smartcards were used to make payments in the rural social security pensions (SSP) program. However, improvements in SSP implementation are unlikely to affect labor markets because the SSP program was targeted to the rural poor who were not able to work ${ }^{11}$ We test and show that treatment did not generate income gains in households where all adults were eligible for the SSP (see Table A.4.

In principle, the creation of Smartcard-linked bank accounts could have also affected labor market outcomes indirectly through promoting financial inclusion. In practice, this was highly unlikely as (a) the government asked banks to fully disburse NREGS wage payments as soon as possible and not leave balances in the account, and (b) the accounts had limited functionality: they were not connected to the online core banking servers, relied on offline authentication, and could only be accessed through a single banking correspondent (see Appendix A.3 in MNS for more details). Reflecting these facts, only $0.3 \%$ of households in our endline survey reported having money in their account 12

Overall, the Smartcards reform was run with the primary goal of improving the payments process and reducing leakage in the NREGS and SSP programs. It was not integrated into any other program or function either by the government or the private sector. We therefore interpret the results that follow as consequences of improving NREGS implementation.

\section{Research Design}

Our study uses the same experimental design as in MNS. The experiment was originally designed to study the effects of Smartcards on NREGS implementation quality, and our primary data collection reflected this goal. This paper aims to study the downstream effects of improving NREGS implementation on the overall rural economy, and uses both our survey data as well as several additional data sources to capture impacts on the overall economy.

\footnotetext{
${ }^{11}$ Specifically, pensions were restricted to those who are Below the Poverty Line (BPL) and either widowed, disabled, elderly, or had a displaced traditional occupation. The scale and scope of SSP is far narrower than that of the NREGS: only 7\% (as opposed to 49.5\%) of rural households are eligible, and the benefit is modest, with a median and mode of Rs. 200 per month ( $\sim 33$, or less than two days earnings for a manual laborer). Finally, the impact of Smartcards on SSP was much less than on NREGS: we found no changes in the payments process, and a small reduction of leakage from $6 \%$ to $3 \%$, in part because payment delays and leakage rates were low to begin with.

12 Field et al. (2021) report evidence consistent with this view: they find that opening bank accounts and paying NREGS wages into them in Madhya Pradesh had no effect on women's labor supply unless accompanied by training on how to use these accounts, in which case account balances increased. No such training was provided along with Smartcards.
} 


\subsection{Randomization}

The experiment was conducted in eight districts with a combined rural population of around 19 million in the erstwhile state of Andhra Pradesh (AP) ${ }^{13}$ The Govt. of AP agreed to randomize the order in which mandals (sub-districts with an average population of $\sim 62,500$ ) within these districts received Smartcards. We randomly assigned 296 mandals to treatment waves, stratifying by district and by a principal component of mandal socio-economic characteristics ${ }^{14}$ We assigned mandals to treatment (112), "buffer" (139), and control (45) groups, to be treated in that order; we chose this design to give us time to conduct endline surveys in treatment and control mandals while the government deployed Smartcards in buffer mandals. Figure A.1 shows the geographical spread and size of these units. We only collected survey data in treatment and control mandals (study mandals), and did not do so in the "buffer" or other mandals outside the study. As reported in MNS, treatment and control mandals are generally well-balanced on stratification variables, and other census variables (Table A.2), and also on household characteristics from our survey (Table A.3) ${ }^{15}$

\subsection{Data}

We next summarize our main data sources; Appendix C provides further detail, including the construction of every outcome in Table C.4.

We drew our survey sample from administrative data on the universe of registered NREGS beneficiaries. Our sample is based on a panel of 880 Gram Panchayats ("GPs," groups of villages) across the 157 study mandals, and a repeated cross-section of households within these GPs, yielding a target sample of 5,278 households at endline ${ }^{16}$ We over-sampled households that were listed as having recently been paid in order to gain precision in estimating leakage in MNS. We therefore re-weight the observations to make all estimates representative of the population of jobcard-holding households (who are the ones eligible to work on NREGS). This population made up $49.5 \%$ of rural households in Andhra Pradesh (our calculations from the NSS Round 68 in 2011-12) and likely represents the entire universe of rural workers

\footnotetext{
${ }^{13}$ The original state was divided into two states on June 2, 2014. Since this division took place after our experiment (conducted in 2010-12), we use "AP" to refer to the undivided state. Study districts are similar to AP's remaining 13 non-urban districts on major socioeconomic indicators, including proportion rural, scheduled caste, literate, and agricultural laborers; and represent all three historically distinct socio-cultural regions (MNS Online Appendix, Tables D.1 and D.2).

${ }^{14}$ We dropped 109 of the 405 mandals in study districts prior to randomization, either because the Smartcards program had already started there or because they were entirely urban and hence had no NREGS. These non-study mandals are similar on observables to the 296 randomized mandals (see MNS, Table D.3).

${ }^{15} \mathrm{An}$ independent replication by 3ie has also found the results in MNS to be robust (Atanda, 2019).

${ }^{16}$ We drew a repeated cross-section of households as opposed to a panel due to considerable variation over time on whether specific households report having worked on NREGS.
} 
employed in agriculture 17

As our endline sample was drawn from the register of beneficiaries as of endline, one potential concern is that the intervention might have affected this register itself. In Appendix D we examine this issue, showing that treatment is not associated with differential rates of entry into, exit from, or net change in the beneficiary register. This likely reflects the fact that most households who wanted to work on NREGS would have registered for it by 2010 , five years after program launch.

We conducted baseline and endline surveys during August-September of 2010 and 2012, respectively. We successfully surveyed 4,943 households at endline, or $94 \%$ of our target sample, with no differences in either the rate or the composition of follow up across treatment and control groups (see Appendix D). We asked detailed questions about household members' labor market participation, wages, reservation wages, and earnings during the month of June (the peak period of NREGS participation in AP). We also measured annual household earnings by source on an annual recall basis, as well as stocks of savings, debt, and landholdings. When using survey data on monetary outcomes we truncate the top $0.5 \%$ of observations in both treatment and control groups to remove outliers ${ }^{18}$

The timing of measurement is important in our context given seasonal patterns of labor market activity. NREGS activity usually peaks in April-June, as for example is evident in wage disbursements (Figure 1, Panel A), and then drops with the onset of the monsoon rains and the main agricultural planting season later in the summer. Crops are typically harvested in September-October and in January. That said, the overall rate of work (including both wage employment and self-employment) appears to hold fairly steady throughout the year (Figure 1, Panel D, plotting data from the National Sample Survey). Figure A.2 summarizes the recall periods covered by our survey data as as well as by other data sources we use. In particular, our most detailed labor market outcomes are for June 2012 (as our survey was timed to capture NREGS activity near its peak), a point we discuss further below.

To examine how the Smartcards reform affected the economy more broadly, beyond the $49.5 \%$ of households registered for NREGS, we supplement our survey data with three distinct and entirely independent censuses of income, employment, and livestock assets conducted by the government. The first and most important is the Socio-Economic and Caste Census (SECC), which provides basic information about income for the entire population.

\footnotetext{
${ }^{17}$ In the NSS, $59 \%$ of all workers are part of households that hold a jobcard; in our sampled households, $65 \%$ of workers work primarily in agriculture. This suggests that we can account for agricultural workers representing $59 \% * 65 \%=38 \%$ of the workforce, if anything slightly higher than the 2011 census figure of $33 \%$ who report primarily working in agriculture.

${ }^{18}$ Results are generally robust to including these (Table B.1); we discuss exceptions in the text below, and discuss sensitivity to outliers and to recall issues more generally in Appendices B and C, respectively.
} 
The SECC was a nation-wide census conducted to enable governments to determine which households were "Below the Poverty Line" (BPL) and thereby eligible for various benefits. The survey collected data on income categories for the highest-earning household member, the main source of this income, landholdings, caste, and education. The SECC was conducted in Andhra Pradesh during 2012 using the layout maps and lists of houses prepared for the regular 2011 Census. The data include 1.8 million households in our study mandals. In addition to measuring impacts on income in the entire population and the distribution of these effects, the SECC also allows us to construct measures of landholding concentration.

The second is the Economic Census of India, a nation-wide census of enterprises and employment conducted roughly quinquennially since 1977. It counts enterprises involved in all non-agricultural economic activities, gathering the industrial classification of the enterprise, number of employees, and demographic details of the owner of the enterprise. We use data from the sixth round conducted in 2013, one year after the experiment was over. The third is the Livestock Census of India, a nation-wide census conducted quinquennially by the Government of India, with the 19th round conducted in Andhra Pradesh in 2012.

We also draw on several additional sources. We use expenditure and unit cost data from Round 68 (2011-2012) of the NSS; while overlap between NSS villages and our study mandals is limited to 60 villages, this source uniquely affords consumer goods price measures. We use data on agricultural land use from the District Statistical Handbooks (DSH) published each year by the Govt. of Andhra Pradesh based on data from the Office of the Surveyor General of India. Finally, we use geocoded point locations for each census village from the 2001 Indian Census to construct measures of spatial exposure to treated neighbors.

\subsection{Estimation strategy}

In settings where spillover effects across units are unlikely it is normal to estimate the total effect on treated units using a simple "intent-to-treat" specification. In our setting, however, we cannot rule out spillovers a priori. If improving the NREGS has general equilibrium effects, there is no reason to expect these to be neatly confined within mandals 19 We therefore estimate the total treatment-on-treated effect using an augmented model:

$$
Y_{i p m d}=\alpha+\beta_{T} T_{m d}+\beta_{N} N_{p m d}^{R}+\gamma \bar{Y}_{p m d}^{0}+\delta_{d}+\lambda P C_{m d}+\epsilon_{i p m d}
$$

Here $Y_{i p m d}$ is an outcome for household or individual $i$ in gram panchayat $p$ in mandal $m$ and district $d$. The direct effects of treatment are captured in this specification by the coefficient

\footnotetext{
${ }^{10}$ Merfeld (2019) finds intra-district differences in wage effects of NREGS as a function of distance to the border, suggesting that SUTVA may not hold.
} 
$\beta_{T}$ on an indicator $T_{m d}$ for assignment to the treatment group, while any indirect effects are captured by the coefficient $\beta_{N}$ on a measure $N_{p m d}^{R}$ of the intensity with which the area in the neighborhood of a given gram panchayat (but outside its own mandal) was treated. Controls include the GP mean $\bar{Y}_{p m d}^{0}$ of the baseline value of that outcome (when available) ${ }^{20}$ district fixed effects $\delta_{d}$, and the first principal component $P C_{m d}$ of a vector of mandal characteristics used to stratify randomization 21 We then define our adjusted estimate of the total effect on the treated as

$$
\text { Adjusted TE }=\hat{\beta}_{T}+\hat{\beta}_{N} \cdot \bar{N}_{T}
$$

where $\bar{N}_{T}=36 \%$ is the mean of $N_{p m d}^{R}$ among gram panchayats in treated mandals. We will refer to this quantity as the AdjTE for short to distinguish it from the Average Treatment Effect (ATE). We also report the components $\hat{\beta}_{T}$ (main effect) and $\hat{\beta}_{N} \cdot \bar{N}_{T}$ (neighborhood effect) separately in all tables ${ }^{22}$

To the extent that an ITT estimator is biased by spillover effects, this adjusted estimator will help to correct that bias. If on the other hand effects do not spill over across mandal boundaries then $N_{p m d}^{R}$ can be interpreted as an irrelevant control variable, and $\hat{\beta}_{T}$ and the ITT estimator are asymptotically equivalent. However, this correction comes at the cost of precision, as we must estimate the contributions of two distinct terms. Which approach is a priori preferable thus depends on one's priors about spillovers and on the relative importance one places on point estimation as opposed to hypothesis testing. Given this we present the AdjTE for main effects on all outcomes, but also provide a parallel set of ITT estimates in Appendix I $]^{23}$ When testing for heterogeneity we focus on ITT effects, since it is not easy to interpret heterogeneity in spillovers, and including spillovers would double the number of parameters to be estimated (including all interactions) and further reduce precision.

We define our measure $N_{p m d}^{R}$ of neighborhood treatment intensity as the proportion of GPs located within $20 \mathrm{~km}$ of GP $p$ and in other mandals which were assigned to treatment. This is a simple and intuitive way to capture spillover effects as a linear combination of

\footnotetext{
${ }^{20}$ We control for the baseline mean rather than household $i$ 's baseline outcomes as our data come from a repeated cross-section. Omitting this control generally does not substantively change our results (Table B.2; ; we discuss any exceptions below.

${ }^{2} \mathrm{As}$ in MNS, we include the principal component itself rather than fixed effects based on its strata as treatment status does not vary within a few strata, so that fixed effects require dropping $4 \%$ of the sample. Results using strata fixed effects are substantively unchanged.

${ }^{22}$ One can also predict the "total treatment effect" of a universally scaled up program to be $\hat{\beta}_{T}+\hat{\beta}_{N}$ (since all neighbors would be treated), but we do not present or discuss this estimate given that it involves extrapolating well beyond the average neighborhood exposure to treatment induced by our experiment.

${ }^{23}$ This approach may also be relevant for future experimental studies that may want to test for spatial spillovers. Note that it is important to present both quantities (ITT and AdjTE) for transparency. Showing only the ITT after testing and finding that spillovers are insignificant would be problematic for inference due to the implied data-driven model selection.
} 
treatment indicators for nearby gram panchayats, consistent for example with the approach taken in Miguel and Kremer (2004) and Egger et al. (2020). That said, it necessarily involves a number of judgment calls. In Appendix $\mathrm{F}$ we discuss the reasoning for these and show that our main conclusions are generally robust to a wide range of alternatives, including interpreting "buffer" mandals as partially treated, using an alternative radius, using a smooth rather than a discrete kernel, including same-mandal gram panchayats in the calculation, and modelling spillovers as a higher-order polynomial function of neighborhood treatment intensity. For outcomes observed at the mandal level, we replace $N_{p m d}^{R}$ with its average $N_{m d}^{R}$ over gram panchayats in given mandal $m$. This is a natural generalization, but necessarily less well-powered as we average over much of the GP-level variation within a mandal ${ }^{24}$

We conduct inference for most outcomes using standard errors clustered at the mandal level (the unit of randomization). For outcomes geolocated at the GP level we also report standard errors computed using the method of Conley (2008) which allows for spatial autocorrelation in the error term; these are typically somewhat smaller than clustered standard errors, so we report significance levels conservatively based on the latter. ${ }^{25}$ For SECC outcomes the Conley procedure is computationally infeasible (as we have $1.8 \mathrm{M}$ observations) but we are able to calculate alternative $p$-values using randomization inference as a robustness check. ${ }^{26}$ Regressions using census data are unweighted, while those using survey samples are weighted by inverse sampling probabilities to be representative of the universe of jobcard-holders ${ }^{27}$

\section{Results}

We first present results using our survey data for NREGS-registered households (henceforth, "beneficiaries"), who make up $49.5 \%$ of all rural households and are the households the NREGS was designed to benefit. We then turn to examining impacts on the overall economy using the various censuses. Finally, we use a combination of survey and census data to characterize the distributional effects of the reform. Our primary focus here is on treatment

\footnotetext{
${ }^{24}$ For SECC GPs that we cannot geolocate by matching to the census we replace $N_{p m d}^{R}$ by its mean and include a dummy variable indicating this.

${ }^{25}$ Spatial autocorrelation is unlikely to be a concern for inference on direct treatment effects as treatment is spatially negatively autocorrelated by design (as randomization is stratified geographically), but could be for inference on neighborhood measures which are positively autocorrelated.

${ }^{26}$ We cannot use randomization inference for survey outcomes because our randomization procedure assigned some mandals to the "buffer" wave in which we did not conduct surveys. Re-running this procedure yields a new assignment in which some of the mandals actually assigned to the buffer are re-assigned to treatment or control waves. To estimate a pseudo-treatment effect under this replicated assignment we would need to observe data for these mandals, which we do not.

${ }^{27} \mathrm{We}$ do not follow a pre-registered analysis plan as data collection for this project was complete and a first paper written before widespread use of the AEA RCT registry began in July 2014.
} 
effects on income and its proximate components - wages and employment. We discuss what people do with their additional income in Section 4.2 when we consider mechanisms through which this demand may feed back into wages, employment, and incomes.

\subsection{Impacts on beneficiaries}

\subsubsection{Earnings}

Our first core finding is that the Smartcards reform substantially raised the annual incomes of beneficiaries (Table 1. Column 1). The estimated AdjTE is over Rs. 9,500 per household per year, driven largely by the main effect of treatment with a smaller, statistically insignificant contribution from the neighborhood effect. The AdjTE is equal to $13.9 \%$ of the control group mean or $19.6 \%$ of the national expenditure-based rural poverty line for a family of 5 in 2011-12, which was Rs. 48,960. Expenditure- and income-based poverty lines may of course differ, so the comparison is only illustrative. That said, if we examine how many households' incomes moved across the expenditure poverty line we estimate a 7.4 percentage point $(25.8 \%)$ reduction in poverty among beneficiaries. Figure A.3 illustrates this, and more broadly the fact that gains were broad-based throughout the income distribution, with the treatment distribution first-order stochastically dominating that in the control group (with the caveat that this Figure captures main but not adjusted treatment effects).

Next, these income gains were driven primarily by increases in private sector wage labor earnings rather than NREGS earnings (Table 1, Columns 2-5). The latter accounted for an estimated $14 \%$ of the earnings gain (with a marginally significant main effect and a larger but less precise AdjTE). Meanwhile, market wage earnings rose substantially and significantly, and accounted for $80 \%$ of the AdjTE on total income. Income from other sources did not change significantly: self-employment income (encompassing farm and non-farm earnings) fell slightly $(95 \%$ CI of $[-7073,5536])$ and miscellaneous income (encompassing private and government employment earnings, along with pensions, gifts and any other income) increased slightly $(95 \%$ CI of $[-2385,7388])$.

This pattern of effects aligns with the structure of control group earnings, where NREGS earnings account for just $7 \%$ of the total while wage labor earnings account for $35 \%$. This in turn is broadly consistent with nationally representative statistics, in which the NREGS is a relatively small source of employment. Even a proportionately large increase in NREGS earnings such as the one we see here can thus contribute only modestly to overall income growth, while indirect effects through labor market earnings can potentially be much larger.

The importance of labor market earnings is also seen in our analysis of heterogeneity. We do not see substantial differences in income effects along demographic characteristics such as 
caste or education, though these splits are not estimated precisely (Table A.4, Columns 1 \& 2). We do, however, see substantially smaller and insignificant effects for households headed by a widow and those with one or more members eligible for a pension (Columns $3 \& 4$ ), with the differential effect marginally significant in the latter case $(p=0.098)$. Thus, income gains accrued primarily to those who are likely to have participated in the labor market, and not to those who did not work.

\subsubsection{Wages and Employment}

To better understand the drivers of these wage earnings, we turn to more detailed wage and employment data for June 2012 ${ }^{28}$ In addition to data on market wages, we also collected data on reservation wages for all respondents 29

We find that treatment significantly increased respondents' reservation wages by approximately Rs. 6.9, or $7.1 \%$ of the control group mean (Table 2, Column 1), with a significant main effect and a small and insignificant spillover effect. The increase in reservation wage provides direct evidence that the reform made NREGS a more appealing outside option. We find no evidence of spatial spillovers in reservation wages, which is consistent with the legal requirement that jobcard holders could only do NREGS work in their own villages. 30

Consistent with the increase in reservation wages in treated areas, we also see large increases in market wages (Table 2, Column 2). The AdjTE is a Rs. 13 increase on a base of Rs. 128 per day, or $10.2 \%$. Of this effect, roughly $2 / 3$ is the main effect, and the remaining $1 / 3$ is a (statistically significant) spillover effect. The interpretation is that having $36 \%$ of ones' neighbors treated (the average neighborhood exposure induced by the experiment) led to half as big an effect as that of receiving treatment oneself. Equivalently, failing to adjust for these spillovers would bias our estimated wage effects downwards by $33 \% .31$

The spillover results independently corroborate the hypothesis test based on the main ef-

\footnotetext{
${ }^{28}$ We report results for all adults, including those who identify primarily as workers but also some who identify as primarily students, houseworkers, or retirees, as the latter do report positive amounts of work. Control means are thus an average across individuals working full- and part-time (see Table E.1 for a crosstabulation). Full-time adult male workers reported working 22 days out of the previous 30, or slightly more than 5 days per week. Results are robust to re-weighting wage data by days worked (see Appendix E).

${ }^{29}$ We asked respondents if in the month of June they would have been "willing to work for someone else for a daily wage of Rs. X," where X started at Rs. 20 (15\% of average wage) and increased in Rs. 5 increments until the respondent agreed. One advantage of this measure is that it applies to everyone, and not only to those who actually worked. Respondents appeared to understand the question, with $98 \%$ of those who worked reporting reservation wages less than or equal to the wages they actually earned (Table D.1).

${ }^{30}$ This result is also consistent with our finding no significant spillovers in measures of program implementation quality from the Smartcards intervention (Tables E5-E7 of MNS).

${ }^{31}$ We show in Appendix E that our main conclusions are robust to alternative weighting of wages (by days of work rather than by worker), that treatment did not significantly alter workforce composition on a large set of characteristics, and that the (insignificant) changes we do see cannot explain the wage effects.
} 
fect, rejecting the null in the same direction, using a different source of exogenous variationthe fraction of neighbors outside a GPs own mandal that were randomly assigned to treatment 32 They also suggest that rural labor markets in this setting are spatially integrated beyond individual GPs or even mandals. Specifically, the results show that there was greater upward pressure on market wages when a larger share of nearby workers were treated, and consequently had higher reservation wages 33

These wage increases only partly explain increases in labor market earnings; we also see an increase of 1.4 days per month (18\%) in private-sector employment (Column 5, $p=0.08$ ). Here the main effect and neighborhood effect are quantitatively similar, the latter marginally significant ${ }^{34}$ Days worked in the NREGS also increased significantly by 1.3 days per month (29\%) (Column 4, $p=0.02$ ), consistent with the findings reported in MNS, and the NREGS earnings gains in Table 1$]^{35}$ These days replace time spent in self-employment or not working, which fell by 2.4 days per month (14\%) (Column 3, $p=0.003$ ). In Appendix E we show that this reduction was driven primarily by a significant reduction in days not working, with a smaller reduction in days of self-employment (Table E.2).

Taken together, the wage and employment point estimates in Table 2 imply a $29 \%$ increase in June labor market earnings, which aligns well with the $32 \%$ increase in annual labor market earnings in Table 1$]^{36}$ We do not observe the same detailed individual employment and earnings data year-round to make this comparison exact. We did, however, ask village leaders to report the "going wage rate" in their communities for each month of the year. Estimated impacts on this measure are imprecise (as we have only a maximum of three data points per village-month), but suggest that wage gains were sustained to some extent through the year (Figure 1, Panel C) ${ }^{37}$ This is consistent with the fact that almost all study

\footnotetext{
${ }^{32}$ We also reject the joint null of no spillovers for any of the outcomes in Table $2(p<0.01)$, despite the fact that a priori we would not expect to spillovers in reservation wages. The evidence of spillovers also corroborate our interpretation of treatment effects as being driven by the labor market effects of an improved NREGS, since channels such as improved pensions and financial inclusion should only matter within treated areas and not beyond.

${ }^{33}$ Note that an increase in worker bargaining power does not have to lead to higher wages through direct negotiation. If their participation constraint goes up (as seen by the increased reservation wages), employers will need to raise wages simply to get workers to show up.

${ }^{34}$ Note that if we omit the baseline control this $p$-value increases slightly to 0.10 (Table B.2.

${ }^{35}$ We use here the sample of workers who reported their private-sector work. For the NREGS outcome we can also expand our sample if we impute zeros for individuals who reported (earlier in the survey) that they had never worked on NREGS; doing so yields similar results (Table B.3).

${ }^{36}$ That is, $[(128+13) / 128] \times[(7.9+1.4) / 7.9]-1=29 \%$. We use the spillover-adjusted estimates for this comparison. While we do not reject the null that the spillover effect for labor market earnings in Table 1 is zero $(p=0.46)$, we also do not reject the null that it is proportionate to the corresponding spillover effects on wages and days worked in Table 2, using the same proportion as that we observe between the main effects $(p=0.29)$. The point estimates should be interpreted keeping this uncertainty in mind.

37 Imbert and Papp (2015) report a similar pattern, with positive but imprecise wage impacts in the "rainy season" amounting to $61 \%$ of the dry season impact they focus on.
} 
villages had at least one NREGS project active through most of the year, with availability dropping to a low of 40-50\% of villages toward the end of the year (Figure 1. Panel B), so that the NREGS remained a credible outside option if not a major employer through much of the year. It may also reflect mechanisms through which wages are linked across time. ${ }^{38}$

Another potentially important influence on households' earnings is migration patterns. Here, however, we do not see strong or consistent evidence of an effect (Table A.5). Across five indicators, the signs of the estimated effects suggest less migration in two cases (non-response due to migration and household size) and more migration in the other three (whether any member migrated, total days of individual migration, and whether local leaders reported migration was common in May); only the indicator for whether any member migrated is significant $(p=0.08)$. Overall this mixed pattern of results may reflect the offsetting price and income effects that higher rural wages would be expected to have, reducing the incentive while increasing the ability to migrate (Bryan et al., 2014; Bazzi, 2017) 39

\subsubsection{Prices and Land Returns}

Given that the reform impacted wages, it is also possible that it affected the local prices of final consumer goods, and thus the overall price level facing consumers. In this case the nominal earnings effects we reported above would overstate the real gains to beneficiaries.

We examine price effects using data from the 68th round of the NSS, collected in 2011-12. The survey contains detailed household $\times$ item-level data on expenditure and number of units purchased for a sample representative at the state and sector level (rural and urban). The data covers over 300 goods and services in categories including food, fuel, clothing, rent and other fees or services over mixed reference periods varying from a week to a year. We define unit costs as the ratio of expenditure to units purchased, restricting the analysis to goods that have precise measures of unit quantities (e.g. kilogram or liter) and dropping goods that likely vary a great deal in quality (e.g. clothes and shoes). We then construct an index equal to the price of purchasing the mean bundle of goods in the control group

\footnotetext{
${ }^{38}$ These include nominal wage rigidity $($ Kaur, 2019$)$ and labor tying over the agricultural cycle (Bardhan, 1983: Mukherjee and Ray, 1995, Anderson et al. [2015). The latter literature in particular suggests that landlords who provide insurance in the lean season pay lower wages in the peak season. In these models, better NREGS availability and higher market wages in the lean season would imply a reduced need for insurance from landlords and a resulting higher wage in the peak (non-NREGS) season.

${ }^{39}$ Imbert and Papp (2019) find evidence that the NREGS rollout reduced short-term migration. However, their results are driven by effects in traditional migrant-sending states such as Bihar, Uttar Pradesh, and Rajasthan, and they report that our study districts have among the lowest seasonal migration rates in India (see Figure 4 in their paper), suggesting the contexts are quite different.
} 
following Deaton and Tarozzi (2000):

$$
P_{v d}=\sum_{c=1}^{n} \bar{q}_{c d} \tilde{p}_{c v}
$$

Here $\bar{q}_{c d}$ is the average number of units of commodity $c$ purchased in panchayats in control areas of district $d$, and $\tilde{p}_{c v}$ is the median unit cost of commodity $c$ in village $v$. Conceptually, treatment effects on this quantity measure the compensating variation required to enable households to continue purchasing their old bundle of goods at the (potentially) new prices.

In our preferred approach we restrict attention to goods and services purchased at least once in every village in our sample. This ensures that we are not picking up compositional effects on the basket of goods purchased, but has the drawback of excluding roughly $40 \%$ of the expenditure per village in our sample. We therefore complement it with a version applying Equation (3) to all available data, and also report effects on the log of unit costs defined at the household-commodity level and including all available data. These later specifications may capture some compositional effects, but do not drop any information.

Regardless of method, we do not see evidence of price appreciation (Table 3). The point estimate using our preferred method actually suggests a decrease of $6 \log$ points, though it is not very precisely estimated $(95 \% \mathrm{CI}$ of $[-0.32,0.20])$. Using either of our alternative methods we obtain estimates very close to zero and precise enough to reject effects as large as the $14 \%$ increase in earnings we observe ${ }^{40}$

One implication of these results is that the costs of higher unskilled wages were absorbed by employers, rather than passed through to consumers. In the agricultural sector in particular (where the majority of beneficiaries worked) this implies that the profits of landowners should have fallen. While our sample of NREGS jobcard-holders likely does not include the larger landholders and other employers we would expect to be hurt by higher wages, our data does include holders of some land; $24.6 \%$ of households own 3 or more acres of land (38.3\% among those with a positive amount of land). We can therefore examine how the reform affected the returns on this land. We do this using a variant of Equation 1 augmented with the (log) of landholdings as a control variable, to capture the fact that land earnings and prices are roughly log-linear in acres held with a slope substantially less than one (Figure A.4).

We find that net farm earnings fell significantly by 19 log points, or 21\% (Table 3 , Column 4). This is consistent with the increase in wages, regardless of households' net labor position: even if firms of this scale do not hire much labor in, higher wages would also raise

\footnotetext{
${ }^{40}$ The adjusted $R^{2}$ values in Table 3 are close to 1 . In village-level regressions (Columns 1 and 2) this is because we have data from just 60 villages, and district fixed effects account for a substantial extent of the variation. In the item $\times$ household level model (Column 3) item fixed effects account for much of the variation.
} 
the opportunity costs of family farm labor that could be hired out. The result indicates that a better-implemented NREGS substantially shifted the returns to factor ownership, reducing the returns to land even as it increased the returns to labor. In line with this result, landowners self-report valuations of their land that are lower by 6 log points, or $6.2 \%$ lower (Table 3, Column 5), though this difference is not significant $(p=0.65)$. Together these results point to meaningful economic losses for landholders, in contrast to the large gains experienced by workers. We return to this point in Section 3.3 .

\subsection{Impacts on the broader economy}

We turn next to evidence from government censuses on income and employment. These complement our survey data in three ways. First, the census data include all households and not just jobcard holders, and allow us to understand impacts on population-level outcomes. Second, they provide an independent source of validation of our main survey-data results of higher incomes and employment and lower poverty as a result of the reform. Third, in conjunction with our survey results, they allow us to examine the distribution of impacts.

We begin as above with earnings. The Socio-Economic Caste Census (SECC) classifies households into low, middle, and high-income categories based on whether their highestearning member reported monthly earnings below Rs. 5,000, between Rs. 5,000 and Rs. 10,000, and greater than Rs. 10,000, respectively. By way of comparison, the average control group household in our survey data reported monthly earnings of Rs. 5,800, and so was likely near or below the threshold between the bottom and middle SECC tiers.

We find that the reform shifted a significant share of households from the lowest income category to higher categories (Table 4). This is clearest when we look at the main effects of treatment, which we estimate most precisely, but the same pattern is also evident and significant at the $10 \%$ level in the adjusted treatment effects. We also strongly reject the null of no effect for all three earnings categories when we estimate a simpler ITT specification without spillover effects (Table I.4). Quantitatively, the estimates imply that roughly $3 \%$ of households moved out of the bottom bracket, primarily into the middle one 41 Overall, these results validate using entirely independent census data that the reform had substantial impacts on population-level earnings and poverty.

We turn next to employment. Our survey data arguably provides good coverage of agricultural employment: the majority $(65 \%)$ of workers report working primarily in agriculture, and collectively they can account for most of the agricultural workforce in our study area

\footnotetext{
${ }^{41}$ Given the limited dependent variable we report marginal effects from logit specifications; results from linear probability models are essentially the same.
} 
(see Footnote 17). The Economic Census provides a complementary picture of employment in the non-agricultural sector one year after our survey.

Employment in the non-agricultural sector increased substantially (Table 5, Panel A). The overall AdjTE of 3,307 additional workers per mandal is a large $48.6 \%$ increase relative to the control group mean of 6,797. Looking across subsectors, effects were uniformly positive but largest in manufacturing and construction, wholesale and retail, and "other," with smaller effects in livestock-related firms. Paralleling this employment expansion, the number of nonagricultural firms also increased significantly (Table 5, Panel B). The AdjTE of an additional 1,100 additional firms per mandal represents $29 \%$ of the control group mean. Notice that this is the opposite of what we would expect to see due solely to upward wage pressure: regardless of market structure, higher wages should reduce firm profits and thus induce exit, not entry. The fact that firm count increased and that estimated effects on firm count and employment are positive at all firm sizes (Table A.6) suggests a positive shock to demand for locally produced non-agricultural goods and services, an idea we return to in Section 4.2 .

\subsection{Distributional Impacts}

The positive effects on overall income and employment in independent censuses complement the results from our survey data and suggest that the overall effects of the reform were positive. We turn next to its distributional impacts, combining the SECC and survey data to examine variation across households along two dimensions: status as an NREGS beneficiary, and the relative importance of labor and land endowments.

The SECC includes non-beneficiaries but does not let us isolate impacts on them directly, as it does not record which households have jobcards. We can, however, infer impacts on nonbeneficiaries using a simple decomposition of the overall average treatment effect $\beta^{A l l}$. Since beneficiaries make up $49.5 \%$ of the population and the conditional variance of treatment is the same among both groups (due to random assignment), we can write

$$
\beta^{A l l}=(49.5 \%) \times \beta^{B}+(50.5 \%) \times \beta^{N B}
$$

where $\beta^{B}$ and $\beta^{N B}$ are average effects on beneficiaries and non-beneficiaries, respectively $4^{42}$

Combined with a consistent estimate of $\beta^{B}$ from our survey data, this allows us in principle to consistently estimate $\beta^{N B}$. To implement this idea we need to harmonize the distinct income measures reported in the SECC and in our survey. We do so by constructing outcomes

\footnotetext{
${ }^{42}$ See for example Angrist (1998). Strictly speaking this argument has been demonstrated in a linear regression setting; while we present results here from our default logit specification, results from a linear probability model analogue are essentially identical.
} 
from our continuous survey measure that are comparable to the categorical SECC measures, calibrating the share of total household income accruing to the top earner at $65 \%$ to match that from a separate survey conducted in our 8 study districts in 2014.43

The results (Table A.7) suggest that the earnings gains we observe in the SECC accrued primarily to beneficiaries. Focusing on the $65 \%$ top earner share as our central scenario, the point estimates for beneficiaries are close to double those we see in the SECC overall, which (since beneficiaries are roughly half the population) implies that they can account for the full effect. The inferred estimates for non-beneficiaries are consequently close to zero, and we can reject large effects (e.g. larger than a $0.3 \%$ decrease in share in the lowest earning category). Results are not particularly sensitive to alternative nearby assumptions about the top earner share. Thus, while the reform triggered substantial general equilibrium effects, the pattern of these was such that gains still accrued primarily to the population the NREGS was intended to benefit (jobcard holders).

We next consider distributional impacts by households' endowments of land and labor from the SECC data. We summarize results here, with full details of the analysis in Appendix $\mathrm{H}$. Figure 2 sorts and bins households by landholdings and then for each bin estimates the gains from labor income, losses from land income, and resulting net change in total income. Panel A presents gains from labor income (the bar plot), calculated by multiplying the average number of working-age adults (aged 18-65) in the household in the SECC data (the line plot) by the estimated treatment effects on labor income per working-age adult in the survey data.

Panel B plots losses from land income (bar plots), calculated as average landholdings (line plot) multiplied by the estimated impacts on profits. We consider two possible values for profit reduction: the $6.2 \%$ reduction in land prices estimated in Table 3 , Column 54 and a $2.5 \%$ reduction obtained from a calibrated Cobb-Douglas production function (see Appendix G.3.2). To obtain absolute reductions we multiply these figures by the Rs 10,200/acre average profit in the NSS agriculture survey of 2012.

Panel $\mathrm{C}$ adds these two effects, revealing that the estimated net impact of the reform was positive for almost all citizens. Even using the larger $6.2 \%$ estimate of profit reduction we see that the bottom $92.5 \%$ of households (ordered by landholdings) were better off after the reform, with only large landholders - holding over 7 acres - worse off. Using the model-based $2.5 \%$ estimate of profit reduction net effects are positive even for this top group. Net effects

\footnotetext{
${ }^{43}$ We use the Center for the Monitoring of the Indian Economy's (CMIE) household panel survey, which attributes income to specific household members. In the CMIE panel approximately $65 \%$ of household earnings are attributable to the top earner. We also examine sensitivity to values in $[55 \%, 75 \%]$

${ }^{44}$ We use the estimated $6.2 \%$ reduction in land prices instead of the $19 \%$ reduction in land profits reported in Table 3 because the latter likely also reflect reallocation of labor from respondents own farms to wage labor, and survey responses are unlikely to have imputed the cost of their own labor.
} 
are also positive at all points of the distribution if we order households not by landholding but by percentiles of imputed consumption using the SECC data (Figure H.1; see Appendix $\mathrm{H}$ for details). Overall, this analysis suggests that in addition to causing large gains in average household income, the reform generated net gains for over $92 \%$ of the population, with net losses seen only for large landowners.

\subsection{Comparison with other studies}

We now turn to comparing our results with the existing literature on NREGS, especially Imbert and Papp (2015) (henceforth IP) who provide the best-identified estimates of impact to date. At the outset, we note that there is no a priori reason for the magnitudes to be strictly comparable given that the studies differ in terms of (a) the exact intervention in question (improving implementation versus the initial program rollout), (b) the setting (AP versus all-India or a subset of "star" states that implemented NREGS well), (c) the time period (in 2010-2012 at a more mature stage of implementation versus 2005-2008 during a period of significant implementation challenges), (d) the survey sampling frame (jobcard holders as opposed to all households), and (e) the outcomes measured. At the same time, comparing the patterns of results across studies is helpful for drawing broader lessons regarding the impact of increasing the effective presence of NREGS on the ground - which happens both when the program is rolled out, and when its implementation is improved.

With respect to wages, the $10.1 \%$ increase we observe is similar to the $9 \%$ increase that IP estimate for "star" states (of which Andhra Pradesh was one), and over double their nationwide estimate of $4.7 \%$ (which includes states that initially did not implement the program well). This underscores the importance of the quality of program implementation as well as its presence, and highlights that improving implementation quality may be as first order for achieving intended impacts as rolling out the program itself 45

The main difference between our results and IP's is with respect to employment, as IP estimate a modest negative effect (with an elasticity of -0.38) in the star-states while we estimate a positive one, and can reject the null of the elasticity they estimate $(p=0.07)$. One important explanation, among others, may be differences in the way employment is measured. Specifically, the NSS does not distinguish between self-employment and market employment in its categorization of private employment. Thus, as IP note, their estimated reduction in overall employment in the NSS data may reflect in part or whole a reduction

\footnotetext{
${ }^{45}$ Work by Ravallion et al. (1993) on a precursor EGS in Maharashtra, on the other hand, finds no impact of a higher EGS wage on private-sector wages. The contrast illustrates the importance of implementation: they show that the higher EGS wage led de facto to the rationing of EGS jobs, so that they were not a credible outside option for workers seeking private-sector employment.
} 
in low marginal product self-employment, as opposed to higher marginal product market wage labor. Our data identify these categories separately, and indeed we find a reduction in self-employment (consistent with IP) but an increase in paid private-sector employment. ${ }^{46}$ Importantly, results from the independent Economic Census corroborate the latter result. The currently prevailing view that the NREGS reduced private employment may thus reflect in part the way the NSS measures it.

Turning to income, our results do not have exact analogues in the existing literature because we measure income directly in our surveys and observe income categories in the SECC, whereas the NSS does not do so. The large effects on income we find in both our survey data and in the SECC thus establish a key new result in the NREGS literature. It is also consistent with recent evidence from Cook and Shah (2020) who find that the introduction of NREGS led to an increase in overall economic activity as measured by bank deposits and night-time lights, which they use as proxies for economic activity.

By way of comparison, it is instructive to relate our direct estimates to those which IP construct indirectly from estimated effects on wages and employment. Expressed as a proportion of NSS household per capita expenditure (PCE), they obtain all-India estimates ranging from $5.8 \%$ in the lowest quintile of the PCE distribution to $-0.2 \%$ in the highest (where higher wages reduce the earnings of net employers). This progressive pattern is consistent with our distributional estimates in Figure 2. However, we estimate a larger overall effect, with estimated average earnings gains of $10.9 \%$ of mean PCE among jobcardholding households in AP. We show in Appendix J that this difference is fully explained by the differences in estimated employment effects: using comparable wage changes and IP's estimated employment elasticity of -0.38 instead of ours, we would have seen an estimated income increase of $3.3 \%$ of mean PCE.

Taken together, our results are consistent with IP's for wages as well as (broadly) for the distributional effects of increasing the (effective) presence of the NREGS. The main points of difference are the employment gains we see in both survey and census data and the relatively large effects we see on income. Note that these two differences are closely related since IP do not directly observe income, but indirectly infer it from the wage and employment results.

\footnotetext{
${ }^{46}$ Another source of difference is that our estimates adjust for spillovers, which the NSS data does not allow IP to do. In principle research designs (such as those of IP) that exploit the district-level rollout of the NREGS should capture some of the spillovers that we detect here at the sub-district (mandal) level. However, in practice both units are fairly "small" relative to the $20 \mathrm{~km}$ radius over which we estimate spillovers. In our data, while $99.7 \%$ of GPs are within $20 \mathrm{~km}$ of their mandal border, a substantial $83 \%$ of GPs are located within $20 \mathrm{~km}$ of their district border and would therefore be exposed to cross-district spillovers. Of course, ignoring spillovers should not change the sign of the measured impact (which is better explained by how the NSS measures employment). But our estimated effects on market employment would be smaller and insignificant if we did not correct for spillovers.
} 


\section{Mechanisms \& Discussion}

We now turn to a discussion of the economic mechanisms that could explain our experimental results. We focus first on mechanisms through which the initial "impulse" of an improved NREGS could have affected rural labor markets. In doing so we put special emphasis on understanding the result that both wages and employment increased in tandem. This pattern is key for assessing the overall policy impacts of a more effective NREGS (as it implies an increase in aggregate economic activity), as well as for explaining the large increases in labor income we observe (as the wage increase alone explains less than half the income gains holding employment fixed). We then discuss ways in which these wage and income increases could in turn have affected other parts of the economy. Our goal in this section is not to conclusively rule out any specific channel, but to provide a sense of the relative importance of various mechanisms.

\subsection{Direct impacts on Rural Labor Markets}

We interpret treatment effects through the lens of a canonical theoretical framework (presented in Appendix G). In the model, workers supply labor to the market if the wage offered exceeds their reservation wage, which depends on the quality of NREGS implementation. We characterize the impacts of improving NREGS quality on wages and employment under various combinations of labor supply and demand conditions, including both perfect and imperfect competition among employers. In particular, the model formalizes the idea that an increase in employment must reflect some combination of an outward shift in labor demand

driven by higher labor (revenue) productivity, and an upward shift in labor supply in the context of monopsonistic labor markets. We consider both channels in turn.

\subsubsection{Labor Productivity}

An improved NREGS could boost labor demand in three ways. First, it could increase the marginal product of labor by augmenting the stock of complementary physical capital. Second, it could directly make workers more productive through human capital channels such as improved nutrition or skills. Third, increased income from NREGS could boost demand for goods produced using local labor. We examine the first two (productivity) channels here, and the third (demand) channel in Section 4.2 .

With respect to complementary capital inputs, an increase in NREGS participation could have increased the quantity or quality of public assets such as roads, ponds, and canals created under it. Such improvements could make labor more productive. However, calculations 
based on our model in Appendix G.2 suggest that this asset creation channel was likely to be small. Using a Cobb-Douglas production function with factor shares estimated from the NSS 2012 cost of cultivation survey, we calculate that we would need a $59.9 \%$ increase in the rural capital stock to fully account for the increases in wage and employment we find. In contrast, we estimate that all NREGS capital formation during 2010-12 represented $4.4 \%$ of the total rural capital stock. Even if the $28.9 \%$ increase in NREGS days worked (Table 2) led to a proportionate increase in NREGS assets, this would imply a total increase in capital stock due to the intervention of just $1.3 \%$ (4.4\% x $28.9 \%$ ), and thus could account for at most $2.4 \%$ of the $59.9 \%$ increase in rural capital stock needed to explain our results. We also find no significant effects on land use measures that one might expect to respond to rural infrastructure, such as the amount of land under cultivation or on the total area irrigated (Table A.8), ruling out effect sizes larger than $16 \%$ and 10\%, respectively.

With respect to human capital, our survey contains several helpful indicators. One captures whether all members of the household ate at least 3 full meals every day in the last month. The control mean is $97.4 \%$ and the adjusted treatment effect is $1 \%$ and not significant, indicating that basic food security is not a major issue in this population. This suggests that a nutrition-based efficiency wage mechanism (Dasgupta and Ray, 1986) is unlikely to apply here. We also observe the skill level of the work performed by on the NREGS. Consistent with the NREGS requirement that projects use unskilled labor, $97.2 \%$ of survey respondents report doing unskilled manual labor. The others served as a field assistant or "mate", whose job entailed recording attendance and the quantity of work done (e.g. volume of earth removed). Treatment did not change the probability of serving as the mate (Table A.9. Column 2). This suggests that the scope for skill acquisition was quite limited.

More generally, profits from land should be (weakly) increasing in labor productivity (see Appendix G). The negative effects we observe on profits from land thus suggest that increases in labor productivity were unlikely to have been first order.

\subsubsection{Labor Supply and Employer Market Power}

An improved NREGS could also provide a better outside option for workers, shifting the labor supply curve to the private sector inwards and thus driving up wages (see Appendix $\mathrm{G}$ for a formal derivation). This possibility has been widely conjectured (see for instance, Basu et al. (2009)), but has been difficult to establish empirically because existing work typically observes only the market wage, which can reflect changes in either labor supply or demand. Our data on reservation wages allows us to test this hypothesis, and the increase in reservation wage in treated areas of Rs. 6.9 , or $7.1 \%$ of the control group mean (Table 2 , 
Column 1), provides direct evidence that labor supply shifted inwards 47

The effects of higher reservation wages on employment are ambiguous and depend on market structure. If labor markets were competitive, it should lead to a reduction in market employment - especially in the absence of meaningful increases in labor productivity, as shown in the previous section. However, if employers have market power to set wages, this need not be true. This is easiest to see in the case where NREGS and private sector jobs are perfect substitutes, in which case the NREGS wage acts as a binding minimum wage, but as we illustrate in Appendix $\mathrm{G}$ the result also holds more generally.

We have already seen one piece of suggestive evidence in Table 2 pointing to imperfectly competitive labor markets in the fact that market wages increased by considerably more (Rs. 13) than the increase in reservation wages (Rs. 6.9). This is consistent with the fact that employment rose (for which the wage increase would need to more than compensate for the reservation wage increase) but not with competitive labor markets, in which the market wage should go up by no more than reservation wages.

To test for this possibility more formally we construct a measure of employer concentration, a commonly-used proxy for market power. Specifically, we use household level data on landholdings from the SECC to construct a normalized Herfindahl-Hirschman index $\left(H^{*}\right)$ of landholding concentration at the village level ${ }^{48}$ We then test for the existence of employer market power by examining if treatment effects on employment vary with $H^{*}$.

We find that villages with greater land concentration had both lower levels of employment, and also significantly larger positive treatment effects on employment (Table 6, Column 1). Both facts are consistent with monopsonistic labor markets 49 To better interpret the

\footnotetext{
${ }^{47}$ This is consistent with descriptive evidence that the private sector competes for labor with the NREGS. First, there is substantial overlap in the distribution of earnings per day in the two sectors (Figure A.5) keeping in mind that many non-wage characteristics also matter. Second, the same people often work in both sectors: in June, $64 \%$ of workers who did some private sector work also did some NREGS work, and $51 \%$ of those who did some NREGS work also did some private sector work. When we asked individuals who had done NREGS work what they would have done if they had been unable to get it, only $6.5 \%$ reported that their alternative would at any point have been to not work; the remaining $93.5 \%$ reported that their alternative would always have been to work in the private sector.

${ }^{48} \mathrm{We}$ calculate the $H^{*}$ as follows: $H_{p}=\sum_{i=1}^{N} s_{i}^{2}$, where $s$ is the share of the village's land owned by each household $i$ in village $p$, and $N$ is the total number of households in the village. We then normalize $H$ to arrive at $H_{p}^{*}=\frac{H_{p}-\frac{1}{N_{p}}}{1-\frac{1}{N_{p}}}$. We also calculate an alternate measure of $H^{*}$ using only households with more than 1 acre of land, since those with less than an acre of land are less likely to use hired labor. Since the SECC was conducted after the treatment, we verify that the treatment did not affect land concentration: the mean difference in $H^{*}$ is $0.0001, p=0.9$, Table A.10.

${ }^{49}$ As shown in Appendix G, employment should fall if wages rise in competitive markets (with no productivity gains), whereas it can increase in the presence of employer market power, making the differential effects on employment by $H^{*}$ the sharp test of employer market power. Differential predictions for effects on wages are not sharp, depending for example on the cross-sectional covariation between market wages, reservation wages, and land concentration. For completeness we nevertheless report the corresponding results (Table A.11). We cannot draw any strong conclusions, as interaction terms are estimated fairly imprecisely and
} 
magnitudes of these effects, we also present the results for a standardized version of $H^{*}(\mu$ $=0, \sigma=1$ ) in Column 3. Treated villages whose land concentration is $1 \sigma$ above the mean had 0.55 days of additional private-sector employment (Table 6. Column 3). These results also hold when we construct $H^{*}$ using only landholdings above 1 acre (Columns 2 and 4).

The $H^{*}$ we compute is likely to understate the concentration of effective wage-setting power. For instance, as suggested by Anderson et al. (2015), landholders of the same subcaste (jati) may collude, making effective land concentration higher than that measured by the $H^{*}$ of household-level landholdings. Unfortunately, data on jati in the SECC has not been released by the Government of India. Yet, even this imperfect measure of concentration accounts for $23.2 \%$ of the positive effects on employment we find 50

To quantify employer market power economically the appropriate measure is the wedge between wages and the marginal product of labor, determined by the elasticity of labor supply facing individual employers. While we do not observe the employer-level data necessary to estimate these individual elasticities, we show in Appendix $\mathrm{G}$ that we can identify the aggregate labor supply elasticity using the estimated moments in our data (in particular, exploiting the fact that we observe reservation wages). Using this approach we estimate an aggregate elasticity of 3.07 (albeit imprecisely) ${ }^{51}$ Since employer-specific elasticities are presumably greater than the aggregate elasticity, this in turn bounds the market power of any individual employer, implying that workers receive at least $75 \%$ of their marginal product.

By way of comparison, Sokolova and Sorensen's (2021) review of studies across a range of labor markets finds an average firm-level elasticity among "best-practice" studies of 7.1, implying that workers receive $88 \%$ of their marginal product, with a $95 \%$ confidence interval from $64 \%$ to $93 \%$. Our estimate of the aggregate elasticity lies towards the lower end of this range, meaning that our results are consistent with a relatively substantial degree of employer market power. These results are also consistent with those in Soundararajan (2019), who finds suggestive evidence of monopsonistic labor markets in India: better enforcement of minimum wage laws increases both market wages and employment.

\subsection{Effects on the Broader Economy}

The initial impacts of the reform on rural labor markets and incomes likely had downstream effects on the broader economy, which could also generate feedback to rural labor markets. To the extent households spent their additional income on locally-produced goods and services

signs vary depending on the measure of land concentration we use.

${ }^{50}$ The mean $H^{*}$ in our data is 0.021 , and the coefficient on $H^{*} \times T$ is 6.5 (Table 6. Column 2). Multiplying the 2 gives us 0.1365 which is $23.2 \%$ of the total effect on employment of 0.5865 days $(0.45+0.1365)$.

${ }^{51} \mathrm{~A} 95 \%$ CI derived via the delta method is $[-3.89,10.02]$. The high variance reflects the fact that we must divide by estimated quantities to calculate this figure; see Appendix $\mathrm{G}$. 
(whether for consumption or asset purchases) as opposed to purchasing imported goods or saving through financial intermediaries, this would tend to stimulate economic activity. Higher wages, on the other hand, could dampen employment and economic activity in more competitive sectors of the labor market.

We examine treatment effects on consumption, savings, and assets in survey data in Table 7. Our survey focused on measuring income as opposed to consumption, and hence contained a very abbreviated single-page expenditure module. Using this data we estimate a small increase equivalent to $4 \%$ of the estimated income gain, but also cannot reject changes ranging from $-92 \%$ to $+100 \%$ of the income gain at the $95 \%$ confidence level (Column 1). The NSS, on the other hand, contains a far more detailed consumption module, but for a much smaller sample of NREGS beneficiaries. Using the NSS we estimate a increase that is larger than the estimated earnings gain, but again not precisely estimated (Column 2), though we do marginally reject the null that the main effect of treatment was zero $(p=0.07)$. Together these two data points suggest a positive marginal propensity to consume, but are consistent with a wide range of possibilities.

In terms of balance sheet outcomes, we see an insignificant increase in liquid savings by Rs. 260 , or $9 \%$ of the control mean. We see more substantial changes in total borrowing (by Rs. 20,400 or 30\%) and the probability of owning land (by 7.2 percentage points or 12\%) (Columns 3-5). Our survey did not cover holdings of livestock, but analysis of data from the 2012 livestock census suggests a shift in holdings from cattle to (more lucrative) buffaloes (Table A.12). However, the estimated treatment effect on the total value of livestock is small $(5.2 \%)$ and reasonably precise with a $95 \%$ CI of $[-9.1 \%, 19.7 \%]{ }^{52}$

Two features of the borrowing increase are worth highlighting. First, it is driven by informal borrowing, as opposed to borrowing from formal financial institutions (Table A.13. Columns 2-4). Second, it is driven by borrowing to offset negative shocks (e.g. unemployment) or cover the costs of major events (e.g. weddings), not to invest in productive assets, consumer durables, or refinancing (Columns 5-9). Increased household earnings thus did not "crowd in" investment using outside capital, but may have increased borrower and/or lender confidence that informal loans could be repaid 53

However, the key point to note is that both the level of financial savings and the treatment effect on savings are very low. Mean household savings stocks are less than $5 \%$ of annual

\footnotetext{
${ }^{52}$ We value livestock at district prices (the lowest level at which the Livestock Census reports them) so that the results reflect treatment effects on price-weighted animal counts, but not on prices themselves. See notes to Table A.12 for further details on the data and calculations.

${ }^{53}$ Both results are also inconsistent with a direct financial inclusion explanation for the other results, and instead consistent with the fact that Smartcards did not enable access to formal financial services beyond NREGS and pension payments themselves.
} 
household expenditure flows, and mean outstanding loans are over twenty times greater than mean savings (Table 7). Similarly, the increase in savings (Rs. 260) is less than 3\% of treatment effects on income (Rs. 9579), and this marginal propensity to save is precisely estimated with a $95 \%$ CI of $[-3.6 \%,+9.0 \%]$. This implies that most of the increased income was either consumed (though we measure this imprecisely) or spent on tangible assets. ${ }^{54}$ Either use of funds would increase local demand as opposed to increasing deposits in the financial system and being deployed elsewhere.

While we do not observe how this spending was allocated across the agricultural and nonagricultural sectors, there are several reasons to think that it was concentrated on the latter. First, it is well-established that the income elasticity of demand for food crops (the primary agricultural output in AP) is low 55 Second, and consistent with this view, the reduction in farm profits suggests that the net effect of any increased productivity and any increase in demand was not enough to offset the cost of higher wages. Third, and in contrast, the significant increase in the number of non-agricultural firms and employment in these firms documented in the Economic Census suggests that the benefits of increased demand significantly exceeded the cost of higher wages. Finally, the increase in new enterprises is concentrated among small single-proprietor businesses - who are more likely to depend on local demand than to sell further away (Table A.6.).

This increase in demand could also explain some of the income gains in our survey data. While we do not observe the breakdown of employment across agricultural and nonagricultural sectors, we do so for income and see that a little over half of the increase in labor income came from non-farm earnings (Table A.14). This is consistent with an increase in demand for labor outside agriculture (note that the economic census of non-agricultural employment could include jobs done by members of NREGS jobcard owning households) ${ }^{56}$

These results are consistent with growing evidence from other studies of meaningful local demand multipliers from increasing the incomes of the poor in developing countries. For instance, Egger et al. (2020) estimate a fiscal multiplier of 2.4 using a randomized communitylevel experiment of income transfers in rural Kenya, with this expansion concentrated in the non-agricultural sector. In India, Santangelo (2019) finds that positive (rainfall) shocks to

\footnotetext{
${ }^{54}$ The increase in savings is larger (Rs. 1664) and marginally significant if we do not truncate the outcome (Table B.1). However, this would still only amount to $17.3 \%$ [-0.01\%, 35\%] of the increase in income.

${ }^{55}$ For instance, the income elasticity of food expenditure in India was 0.75 and declining with income even in the 1980s Subramanian and Deaton (1996). This figure is likely to be much lower 25 years later and in our setting, where $97 \%$ of households report eating 3 full meals a day every day in the past month.

${ }^{56} \mathrm{It}$ is also possible that some of the increase in non-agricultural employment could be driven by an increase in reservation wages in a context of employer market power outside agriculture as well. While we cannot test this possibility directly, this channel may be less plausible than the boost in aggregate demand given that most of the new enterprises formed were single-employee firms (Table A.6).
} 
agriculture raise rural wages, but also lead to an expansion of non-agricultural employment. This suggests that the positive effects of greater aggregate demand outweighed the potential negative effects of higher wages - a result that is directly relevant to our setting.

These empirical results also echo a well-established theoretical literature in development economics highlighting the possibility of positive feedback mechanisms from higher wages due to demand externalities. Such externalities, it is thought, can accelerate structural transformation and even potentially give rise to multiple equilibria (Rosenstein-Rodan, 1943; Murphy et al., 1993). Magruder (2013) finds that formal employment in non-traded industries rose after an increase in the minimum wage in Indonesia and interprets it similarly, arguing that the coordinated boost to local incomes generated aggregate demand externalities and facilitated a "big push" towards greater formal sector employment. ${ }^{57}$

The magnitude of the effects we find suggest that such a mechanism may also be at play in our setting. The overall AdjTE of 3,307 additional workers per mandal is a nearly $50 \%$ increase relative to the control group mean (Table 5). It is also equivalent to $11.2 \%$ of the entire working-age population of the average mandal (of 29,600). To put this figure in perspective, the share of the Indian workforce engaged in non-agricultural employment had increased by roughly $8 \%$ from 2000 to 2010 (World Bank, 2021). The effects we see within 3 years of the onset of the reform are thus comparable to what one might expect to see from more than a decade of ongoing structural change in the economy.

\section{Conclusion}

This paper contributes to understanding the impact of increasing the effective presence of public employment programs in developing countries, in the context of the largest such program in the world-India's NREGS. Relative to the existing literature, it contributes (a) improved identification: using experimental variation with units of randomization large enough to capture general equilibrium effects and units of measurement granular enough to capture spatial spillover effects; (b) ground-level measures of implementation quality: enabling us to interpret impacts as the results of demonstrable changes in actual presence of the program; (c) new outcome measures: including reservation wages, income, and market employment; with independent census data on the latter two; (d) a more thorough examination of plausible mechanisms of impact including productivity, imperfectly-competitive

\footnotetext{
${ }^{57}$ Higher wages might also promote structural transformation by increasing employer incentives to mechanize production, as for example Hornbeck and Naidu (2014) find for the historical US. There is some evidence of increased mechanization in India as a result of NREGS-driven wage increases (Deininger et al., 2016). However, this channel may not yet have materialized at the time of data collection since estimated effects on farm profits are negative.
} 
labor markets, and aggregate demand.

Overall, our results are consistent with the following broad narrative. Improving NREGS implementation improved its value as an outside option for the rural poor (as seen in increased reservation wages). This in turn forced employers to raise market wages to attract workers. Crucially for efficiency, this raised private employment - at least in part because the wage increase was in the context of imperfectly-competitive labor markets. The positive employment effects amplified the positive wage effects to generate large increases in the incomes of the rural poor. Since very little of this income was saved via financial intermediaries, it likely boosted local demand for goods, services, and assets, contributing to large increases in both the number of non-agricultural firms and employment in these firms.

These results directly contribute to the ongoing debate over the impacts of the NREGS and how much funding it should receive 58 Debate has centered on whether the NREGS can have had a meaningful impact on rural incomes and poverty given that it accounts for only a small share of rural employment (4\% across India in 2011). Skeptics such as Bhalla (2013) ask, "how can a small tail wag a very very large dog?" And even if the NREGS did indirectly raise rural wages, this effect could be offset by crowding-out of private sector employment (Murgai and Ravallion, 2005). Our results show that the NREGS can indeed have large impacts on market wages, and in doing so can raise rather than reduce privatesector employment, leading to large net income gains.

One natural question is how our results on the effects of improving NREGS implementation speak to policymakers in other settings who are considering whether or not to introduce a public employment program from scratch. While the specific impacts will depend on context, program design, and especially (as our paper demonstrates) implementation quality, we see the main implication of our results as follows:

Many economists - including ourselves - were initially skeptical about the likely impact of NREGS on rural poverty. Our prior (following the default view of competitive labor markets) was that wage increases without corresponding gains in productivity would likely reduce private employment and potentially attenuate impacts on poverty. Our findings have reversed these priors. In particular, our finding positive effects on wages, employment, and incomes, and finding evidence of employer market power, suggest that programs like NREGS can not only reduce poverty, but also be efficiency enhancing.59 Since governments often consider public employment programs as a policy response to high unemployment, they are

\footnotetext{
${ }^{58}$ While NREGS is a legislated right under an Act of Parliament, in practice, work availability is constrained by budgetary allocations. For instance, work availability fell sharply in 2016, following a budget cut: http: //thewire.in/75795/mnrega-centre-funds-whatsapp/, accessed November 3, 2016.

${ }^{59}$ In this sense, our results are similar to those of Banerjee et al. (2002) who find that strengthening property rights (and bargaining power) of tenant farmers in West Bengal improved both equity and efficiency.
} 
likely to use them in conditions where employers have more market power than job seekers. In such settings, a public employment program may have positive effects not only on wages, but also on employment and income. Our results also suggest that such a boost to the wages and incomes of the poor may have positive demand multiplier effects on employment and broader economic activity, as also seen recently in Egger et al. (2020).

Our results also highlight political economy issues in the design and implementation of anti-poverty programs in developing countries. Landlords and employers typically benefit at the cost of workers from low wages and from the wage volatility induced by productivity shocks, and may be hurt by programs like NREGS that raise wages and/or provide wage insurance to the rural poor (Jayachandran, 2006). Anderson et al. (2015) have argued that "a primary reason... for landlords to control governance is to thwart implementation of centrally mandated initiatives that would raise wages at the village level." Our distributional analysis shows that the reforms generated broad-based benefits, but also likely hurt a small but politically influential group of large landowners. This may help explain such landowners' documented opposition to NREGS (Anderson et al., 2015; Khera, 2011).

Finally, our results illustrate how the costs of corruption and weak implementation may go beyond the direct costs of diverted public resources and extend to the broader economy Murphy et al., 1993). Empirical work on corruption has made great strides quantifying leakage as the difference between fiscal outlays and actual receipts by beneficiaries (e.g. (Reinikka and Svensson, 2004; Muralidharan et al., 2017)) and studying the impacts of reforms on these measures (Olken, 2007; Muralidharan et al., 2016). Yet the broader economic costs of corruption have been harder to detect. Our results suggest that weak NREGS implementation may hurt the poor much more through diluting its general equilibrium effects than through the diversion of wages per se. Consequently they also underscore the importance of building state capacity for better implementation of social programs in developing countries.

\section{References}

Acemoglu, Daron, "Theory, General Equilibrium, and Political Economy in Development Economics," Journal of Economic Perspectives, 2010, 24 (3), 17-32.

Anderson, Siwan, Patrick Francois, and Ashok Kotwal, "Clientelism in Indian Villages," American Economic Review, 2015, 105 (6), 1780-1816.

Angrist, Joshua D., "Estimating the Labor Market Impact of Voluntary Military Service Using Social Security Data on Military Applicants," Econometrica, 1998, 66 (2), 249-288.

Atanda, Akinwande A, "Biometric Smartcards and payment disbursement: a replication study of a state capacity-building experiment in India," Technical Report, International 
Initiative for Impact Evaluation (3ie) 2019.

Banerjee, Abhijit, Esther Duflo, Clément Imbert, Santhosh Mathew, and Rohini

Pande, "E-governance, Accountability, and Leakage in Public Programs: Experimental Evidence from a Financial Management Reform in India," American Economic Journal: Applied Economics, 2020, 12 (4), 39-72.

_, Paul Gertler, and Maitreesh Ghatak, "Empowerment and Efficiency: Tenancy Reform in West Bengal," Journal of Political Economy, 2002, 110 (2), 239-280.

Bardhan, Pranab K., "Labor-Tying in a Poor Agrarian Economy: A Theoretical and Empirical Analysis," The Quarterly Journal of Economics, 1983, 98 (3), 501-514.

Basu, Arnab K., Nancy H. Chau, and Ravi Kanbur, "A Theory of Employment Guarantees: Contestability, Credibility and Distributional Concerns," Journal of Public Economics, April 2009, 93 (3-4), 482-497.

Bazzi, Samuel, "Wealth heterogeneity and the income elasticity of migration," American Economic Journal: Applied Economics, 2017, 9 (2), 219-255.

Beaudry, Paul, David A Green, and Benjamin Sand, "Does Industrial Composition Matter for Wages? A Test of Search and Bargaining Theory," Econometrica, 2012, 80 (3), $772-793$.

Beegle, Kathleen, Emanuela Galasso, and Jessica Goldberg, "Direct and Indirect Effects of Malawi's Public Works Program on Food Security," Journal of Development Economics, 2017, 128, 1-23.

Berg, Erlend, Sambit Bhattacharyya, Rajasekhar Durgam, and Manjula Ramachandra, "Can Rural Public Works Affect Agricultural Wages? Evidence from India," World Development, March 2018, (103), 239-254.

Bertrand, Marianne, Bruno Crepon, Alicia Marguerie, and Patrick Premand, "Do Workfare Programs Live Up to Their Promises? Experimental Evidence from Cote D'Ivoire," Working Paper 28664, National Bureau of Economic Research April 2021.

Bhalla, Surjit, "The Unimportance of NREGA," The Indian Express, July 242013.

Bryan, Gharad, Shyamal Chowdhury, and Ahmed Mushfiq Mobarak, "Underinvestment in a profitable technology: The case of seasonal migration in Bangladesh," Econometrica, 2014, 82 (5), 1671-1748.

Card, David and Alan Krueger, "Minimum Wages and Employment: A Case Study of the Fast-Food Industry in New Jersey and Pennsylvania," American Economic Review, 1994, 84, 772-793.

Cengiz, Doruk, Arindrajit Dube, Attila Lindner, and Ben Zipperer, "The Effect of Minimum Wages on Low-Wage Jobs," The Quarterly Journal of Economics, 05 2019, 134 (3), 1405-1454. 
Clemens, Jeffrey and Joshua D Gottlieb, "In the Shadow of a Giant: Medicare's Influence on Private Physician Payments," J.P.E, 2017, 125 (1), 1-39.

Conley, Timothy G, "Spatial Econometrics," in Steven Durlauf and Lawrence Blume, eds., The New Palgrave Dictionary of Economics, Houndsmills, 2008, chapter 7, pp. 741-747.

Cook, C. Justin and Manisha Shah, "Aggregate Effects from Public Works: Evidence from India," Technical Report w27395, National Bureau of Economic Research, Cambridge, MA 2020.

Cunha, Jesse, Giacomo DeGiorgi, and Seema Jayachandran, "The Price Effects of Cash Versus In-Kind Transfers," Review of Economic Studies, January 2019, 86 (1), 240-281.

Dasgupta, Partha and Debraj Ray, "Inequality as a Determinant of Malnutrition and Unemployment: Theory," The Economic Journal, 1986, 96 (384), 1011.

Deaton, Angus and Alessandro Tarozzi, "Prices and poverty in India," Technical Report, Princeton University 2000.

Deininger, Klaus, Hari K. Nagarajan, and Sudhir K. Singh, Short-Term Effects of India's Employment Guarantee Program on Labor Markets and Agricultural Productivity, World Bank, Washington, DC, May 2016.

Dinkelman, Taryn and Vimal Ranchhod, "Evidence on the impact of minimum wage laws in an informal sector: Domestic workers in South Africa," Journal of Development Economics, 2012, 99 (1), $27-45$.

Donaldson, Dave and Richard Hornbeck, "Railroads and American Economic Growth: A "Market Access" Approach," Quarterly Journal of Economics, 2016, 131 (2), 799-858.

Dreze, Jean and Amartya Sen, Hunger and Public Action, Oxford U. Press, 1991.

Dube, Arindrajit, Jeff Jacobs, Suresh Naidu, and Siddharth Suri, "Monopsony in Online Labor Markets," American Economic Review: Insights, March 2020, 2 (1), 33-46.

Dutta, Puja, Rinku Murgai, Martin Ravallion, and Dominique van de Walle, "Does India's Employment Guarantee Scheme Guarantee Employment?," Policy Research Working Paper Series 6003, World Bank 2012.

Egger, Dennis, Johannes Haushofer, Edward Miguel, Paul Niehaus, and Michael Walker, "General equilibrium effects of cash transfers: experimental evidence from Kenya," NBER Working Paper Series 26600, National Bureau of Economic Research 2020.

Emerick, Kyle, "Agricultural productivity and the sectoral reallocation of labor in rural India," Journal of Development Economics, 2018, 135, 488-503.

Field, Erica, Rohini Pande, Natalia Rigol, Simone Schaner, and Charity Troyer Moore, "On Her Own Account: How Strengthening Women's Financial Control Impacts Labor Supply and Gender Norms," A.E.R, July 2021, 111 (7), 2342-75. 
Foster, A.D. and M.R. Rosenzweig, "Are Indian farms too small? Mechanization, agency costs, and farm efficiency," Mimeo, Economic Growth Center, Yale University, New Haven CT. 2011.

Harasztosi, Peter and Attila Lindner, "Who Pays for the Minimum Wage?," American Economic Review, August 2019, 109 (8), 2693-2727.

Hornbeck, Richard and Suresh Naidu, "When the Levee Breaks: Black Migration and Economic Development in the American South," American Economic Review, 032014 , 104 (3), 963-990.

Imbert, Clement and John Papp, "Labor Market Effects of Social Programs: Evidence from India's Employment Guarantee," American Economic Journal: Applied Economics, 2015, 7 (2), 233-263.

_ and _ , "Short-term Migration, Rural Public Works, and Urban Labor Markets: Evidence from India," Journal of the European Economic Association, March 2019.

Jayachandran, Seema, "Selling Labor Low: Wage Responses to Productivity Shocks in Developing Countries," Journal of Political Economy, 2006, 114 (3), pp. 538-575.

Kaur, Supreet, "Nominal Wage Rigidity in Village Labor Markets," American Economic Review, October 2019, 109 (10), 3585-3616.

Khera, Reetika, The Battle for Employment Guarantee, Oxford University Press, 2011.

Magruder, Jeremy R., "Can minimum wages cause a big push? Evidence from Indonesia," Journal of Development Economics, 2013, 100 (1), 48 - 62.

Merfeld, Joshua D, "Spatially heterogeneous effects of a public works program," Journal of Development Economics, 2019, 136, 151-167.

Miguel, Edward and Michael Kremer, "Worms: identifying impacts on education and health in the presence of treatment externalities," Econometrica, 2004, 72 (1), 159-217.

Mukherjee, Anindita and Debraj Ray, "Labor tying," Journal of Development Economics, 1995, 47 (2), 207-239.

Muralidharan, Karthik and Paul Niehaus, "Experimentation at Scale," Journal of Economic Perspectives, 2017, 31 (4), 103-124.

_ , Jishnu Das, Alaka Holla, and Aakash Mohpal, "The fiscal cost of weak governance: Evidence from teacher absence in India," Journal of Public Economics, January 2017, 145, $116-135$.

_, Paul Niehaus, and Sandip Sukhtankar, "Building State Capacity: Evidence from Biometric Smartcards in India," American Economic Review, 2016, 106 (10), 2895-2929.

Murgai, Rinku and Martin Ravallion, "Is a guaranteed living wage a good anti-poverty policy?," Policy Research Working Paper Series 3640, The World Bank June 2005.

Murphy, Kevin M, Andrei Shleifer, and Robert W Vishny, "Why Is Rent-Seeking 
So Costly to Growth?," American Economic Review, May 1993, 83 (2), 409-14.

Naidu, Suresh, Yaw Nyarko, and Shing-Yi Wang, "Monopsony Power in Migrant Labor Markets: Evidence from the United Arab Emirates," Journal of Political Economy, 2016, 124 (6), 1735-1792.

Niehaus, Paul and Sandip Sukhtankar, "Corruption Dynamics: The Golden Goose Effect," American Economic Journal: Economic Policy, 2013, 5.

_ and _ , "The Marginal Rate of Corruption in Public Programs: Evidence from India," Journal of Public Economics, 2013, 104, 52 - 64.

Olken, Benjamin A., "Monitoring Corruption: Evidence from a Field Experiment in Indonesia," Journal of Political Economy, April 2007, 115 (2), 200-249.

Ravallion, Martin, Gaurav Datt, and Shubham Chaudhuri, "Does Maharashtra's Employment Guarantee Scheme Guarantee Employment? Effects of the 1988 Wage Increase," Economic Development and Cultural Change, January 1993, 41 (2), 251-75.

Reinikka, Ritva and Jakob Svensson, "Local Capture: Evidence From a Central Government Transfer Program in Uganda," The Quarterly Journal of Economics, May 2004, 119 (2), 678-704.

Rosenstein-Rodan, P. N., "Problems of Industrialisation of Eastern and South-Eastern Europe," The Economic Journal, 1943, 53 (210/211), 202.

Santangelo, Gabriella, "Firms and Farms: The Local Effects of Farm Income on Firms' Demand," Cambridge Working Papers in Economics 1924, Faculty of Economics, University of Cambridge 2019.

Sokolova, Anna and Todd Sorensen, "Monopsony in Labor Markets: A Meta-Analysis," ILR Review, 2021, 74 (1), 27-55.

Soundararajan, Vidhya, "Heterogeneous effects of imperfectly enforced minimum wages in low-wage labor markets," Journal of Development Economics, 2019, 140, 355-374.

Subbarao, Kalanidhi, Carlo Del Ninno, Colin Andrews, and Claudia RodríguezAlas, Public works as a safety net: design, evidence, and implementation, The World Bank, 2013.

Subramanian, Shankar and Angus Deaton, "The Demand for Food and Calories," Journal of Political Economy, 1996, 104 (1), 133-162.

Sukhtankar, Sandip, "India's National Rural Employment Guarantee Scheme: What Do We Really Know about the World's Largest Workfare Program?," India Policy Forum, 2017.

World Bank, "World Development Indicators Online Database," https://datacatalog. worldbank.org/dataset/world-development-indicators 2021. Accessed: 2021-07-16. 
Table 1: Earnings

\begin{tabular}{|c|c|c|c|c|c|}
\hline & $\frac{\text { Total }}{(1)}$ & $\frac{\text { NREGA }}{(2)}$ & $\frac{\text { Wage labor }}{(3)}$ & $\begin{array}{c}\begin{array}{c}\text { Self } \\
\text { employment }\end{array} \\
(4)\end{array}$ & $\frac{\text { Misc. }}{(5)}$ \\
\hline $\begin{array}{l}\text { Adjusted TE } \\
\left(\beta_{T}+0.36 * \beta_{N}\right)\end{array}$ & $\begin{array}{l}9579^{* *} \\
(4539) \\
\{4548\}\end{array}$ & $\begin{array}{c}1295 \\
(1061) \\
\{1154\}\end{array}$ & $\begin{array}{c}7607^{* * *} \\
(2720) \\
\{2968\}\end{array}$ & $\begin{array}{c}-769 \\
(3192) \\
\{3131\}\end{array}$ & $\begin{array}{c}2502 \\
(2474) \\
\{2488\}\end{array}$ \\
\hline $\begin{array}{l}\text { Main effect } \\
\left(\beta_{T}\right)\end{array}$ & $\begin{array}{l}9030^{* *} \\
(3670) \\
\{3483\}\end{array}$ & $\begin{array}{l}1005^{*} \\
(584) \\
\{619\}\end{array}$ & $\begin{array}{l}6804^{* * *} \\
(2130) \\
\{2228\}\end{array}$ & $\begin{array}{l}1123 \\
(2681) \\
\{2602\}\end{array}$ & $\begin{array}{c}872 \\
(2018) \\
\{1959\}\end{array}$ \\
\hline $\begin{array}{l}\text { Nbhd effect } \\
\left(0.36 * \beta_{N}\right)\end{array}$ & $\begin{array}{c}550 \\
(2654) \\
\{2081\}\end{array}$ & $\begin{array}{c}289 \\
(804) \\
\{827\}\end{array}$ & $\begin{array}{c}803 \\
(1099) \\
\{1133\}\end{array}$ & $\begin{array}{l}-1892 \\
(1791) \\
\{1650\}\end{array}$ & $\begin{array}{c}1629 \\
(1699) \\
\{1277\}\end{array}$ \\
\hline Baseline & Yes & No & No & No & No \\
\hline Control mean & $69,122.1$ & $4,743.4$ & $24,120.2$ & $26,563.1$ & $13,695.4$ \\
\hline Adjusted $R^{2}$ & .039 & .015 & .053 & .015 & .013 \\
\hline Observations & 4,823 & 4,856 & 4,857 & 4,857 & 4,857 \\
\hline
\end{tabular}

The unit of analysis is a household. All outcomes are in Rs. per year. "Total" sums all other categories; "Wage labor" includes agricultural and non-agricultural labor; "Self-employment" includes farm and nonfarm business; "Misc." sums all other income (private and government employment earnings, pensions, gifts, and "other"). Estimation is as described in Section 2.3. Appendices Cand B discuss recall and sensitivity to outliers. Standard errors in parentheses are clustered by mandal; those in brackets are spatial as in Conley (2008). Significance based on the former is denoted: ${ }^{*} p<.10,{ }^{* *} p<.05,{ }^{* * *} p<.01$.

Table 2: Employment and wages in June

\begin{tabular}{|c|c|c|c|c|c|}
\hline & \multicolumn{2}{|c|}{ Wage } & \multicolumn{3}{|c|}{ Employment } \\
\hline & $\begin{array}{l}(1) \\
\text { Reservation } \\
\text { wage }\end{array}$ & $\begin{array}{c}(2) \\
\text { Wage } \\
\text { realization }\end{array}$ & $\begin{array}{c}(3) \\
\text { Days self-employed } \\
\text { or not working }\end{array}$ & $\begin{array}{c}(4) \\
\text { Days worked } \\
\text { in NREGS }\end{array}$ & $\begin{array}{c}(5) \\
\text { Days worked } \\
\text { in private sector }\end{array}$ \\
\hline $\begin{array}{l}\text { Adjusted TE } \\
\left(\beta_{T}+0.36 * \beta_{N}\right)\end{array}$ & $\begin{array}{l}6.9^{* *} \\
(3.2) \\
\{3.5\}\end{array}$ & $\begin{array}{l}13^{* * *} \\
(4.3) \\
\{4.6\}\end{array}$ & $\begin{array}{l}-2.4^{* * *} \\
(.79) \\
\{.81\}\end{array}$ & $\begin{array}{l}1.3^{* *} \\
(.55) \\
\{.56\}\end{array}$ & $\begin{array}{l}1.4^{*} \\
(.8) \\
\{.78\}\end{array}$ \\
\hline $\begin{array}{l}\text { Main effect } \\
\left(\beta_{T}\right)\end{array}$ & $\begin{array}{l}5.8^{* *} \\
(2.8) \\
\{2.9\}\end{array}$ & $\begin{array}{l}8.8^{* *} \\
(3.6) \\
\{3.6\}\end{array}$ & $\begin{array}{l}-1.5^{* *} \\
(.59) \\
\{.6\}\end{array}$ & $\begin{array}{l}.89^{*} \\
(.47) \\
\{.51\}\end{array}$ & $\begin{array}{l}.74 \\
(.57) \\
\{.57\}\end{array}$ \\
\hline $\begin{array}{l}\text { Nbhd effect } \\
\left(0.36 * \beta_{N}\right)\end{array}$ & $\begin{array}{l}1.1 \\
(1.7) \\
\{1.7\}\end{array}$ & $\begin{array}{l}4.3^{*} \\
(2.4) \\
\{2.6\}\end{array}$ & $\begin{array}{l}-.95^{* *} \\
(.42) \\
\{.41\}\end{array}$ & $\begin{array}{l}.39 \\
(.27) \\
\{.24\}\end{array}$ & $\begin{array}{l}.71^{*} \\
(.4) \\
\{.38\}\end{array}$ \\
\hline Control mean & 97.2 & 127.9 & 17.3 & 4.5 & 7.9 \\
\hline Adjusted $R^{2}$ & .054 & .076 & .073 & .076 & .020 \\
\hline Observations & 12,677 & 7,016 & 13,951 & 14,009 & 14,278 \\
\hline
\end{tabular}

The unit of analysis is an adult. "Wage realization" is the average daily wage, in Rs. per day, received by adults who worked. "Reservation wage" is the wage at which an individual would have been willing to work for someone else. The outcome in Columns 3-5 is the number of days out of the past 30 spend in the respective occupations. Estimation is as described in Section 2.3. Appendices $\mathrm{C}$ and $\mathrm{B}$ discuss recall and sensitivity to outliers in more detail. Standard errors in parentheses are clustered by mandal; those in brackets are spatial as in Conley (2008). Significance based on the former is denoted: ${ }^{*} p<.10,{ }^{* *} p<.05,{ }^{* * *} p<.01$. 
Table 3: Prices

\begin{tabular}{|c|c|c|c|c|c|}
\hline & \multicolumn{3}{|c|}{ Consumer goods } & \multicolumn{2}{|c|}{$\begin{array}{c}\text { Prices and } \\
\text { rates of return }\end{array}$} \\
\hline & $\begin{array}{c}(1) \\
\text { Index: } \\
\text { uniform goods }\end{array}$ & $\begin{array}{c}(2) \\
\text { Index: } \\
\text { all goods }\end{array}$ & $\begin{array}{c}(3) \\
\text { Individual } \\
\text { goods }\end{array}$ & $\begin{array}{l}\text { Logged own-land } \\
\text { profits }\end{array}$ & $\begin{array}{c}(5) \\
\text { Logged value } \\
\text { per acre }\end{array}$ \\
\hline $\begin{array}{l}\text { Adjusted TE } \\
\left(\beta_{T}+0.36 * \beta_{N}\right)\end{array}$ & $\begin{array}{l}-.055 \\
(.13) \\
\{.13\}\end{array}$ & $\begin{array}{l}.0059 \\
(.045) \\
\{.051\}\end{array}$ & $\begin{array}{c}-.0003 \\
(.016) \\
\{.015\}\end{array}$ & $\begin{array}{c}-.19^{* *} \\
(.08) \\
\{.076\}\end{array}$ & $\begin{array}{l}.06 \\
(.13) \\
\{.15\}\end{array}$ \\
\hline $\begin{array}{l}\text { Main effect } \\
\left(\beta_{T}\right)\end{array}$ & $\begin{array}{c}-.0072 \\
(.079) \\
\{.082\}\end{array}$ & $\begin{array}{l}.0072 \\
(.029) \\
\{.032\}\end{array}$ & $\begin{array}{r}-.0071 \\
(.011) \\
\{.011\}\end{array}$ & $\begin{array}{c}-.09 \\
(.075) \\
\{.065\}\end{array}$ & $\begin{array}{l}-.061 \\
(.11) \\
\{.11\}\end{array}$ \\
\hline $\begin{array}{l}\text { Nbhd effect } \\
\left(0.36 * \beta_{N}\right)\end{array}$ & $\begin{array}{l}-.048 \\
(.057) \\
\{.059\}\end{array}$ & $\begin{array}{c}-.0014 \\
(.019) \\
\{.023\}\end{array}$ & $\begin{array}{c}.0068 \\
(.0073) \\
\{.0075\}\end{array}$ & $\begin{array}{l}-.1^{* *} \\
(.042) \\
\{.042\}\end{array}$ & $\begin{array}{l}.0018 \\
(.053) \\
\{.059\}\end{array}$ \\
\hline Item FE & No & No & Yes & $\mathrm{No}$ & No \\
\hline Unit of analysis & Village & Village & Item x Household & Household & Household \\
\hline Control mean & 11.1 & 10.7 & -3.1 & 10.0 & 11.7 \\
\hline Adjusted $R^{2}$ & .982 & .998 & .951 & .261 & .173 \\
\hline Observations & 58 & 58 & 17,651 & 2,487 & 3,053 \\
\hline
\end{tabular}

The outcome in Columns $1 \& 2$ is the log of the village-level price indices constructed using Equation 3 Column 1 restricts the sample to goods purchased at least once in every village. The outcome in Column 3 is the log of the individual commodity price. "Own-land profits" is the log of the household's income from their owned land. "Value per acre" is the log value per acre of a household's landholdings. Estimation is as described in Section 2.3. Appendices $\mathrm{C}$ and $\mathrm{B}$ discuss recall and sensitivity to outliers in more detail. Standard errors in parentheses are clustered by mandal; those in brackets are spatial as in Conley (2008). Significance based on the former is denoted: ${ }^{*} p<.10,{ }^{* *} p<.05,{ }^{* * *} p<.01$.

Table 4: Income categories (SECC data)

\begin{tabular}{|c|c|c|c|c|}
\hline & $\begin{array}{c}\text { Lowest bracket } \\
(<\text { Rs. } 5,000)\end{array}$ & $\begin{array}{c}\text { Middle bracket } \\
\text { (Rs. } 5,000-10,000)\end{array}$ & $\begin{array}{c}\text { Highest bracket } \\
(>\text { Rs. } 10,000)\end{array}$ & $\begin{array}{c}\text { Income bracket } \\
3 \text { levels }\end{array}$ \\
\hline & (1) & (2) & (3) & (4) \\
\hline $\begin{array}{l}\text { Adjusted TE } \\
\left(\beta_{T}+0.36 * \beta_{N}\right)\end{array}$ & $\begin{array}{l}-.028^{*} \\
(.017) \\
{[.084]}\end{array}$ & $\begin{array}{c}.025^{*} \\
(.014) \\
{[.03]}\end{array}$ & $\begin{array}{c}.0034 \\
(.0069) \\
{[.42]}\end{array}$ & $\begin{array}{l}-.026 \\
(.017)\end{array}$ \\
\hline $\begin{array}{l}\text { Main effect } \\
\left(\beta_{T}\right)\end{array}$ & $\begin{array}{c}-.032^{* *} \\
(.014) \\
{[.02]}\end{array}$ & $\begin{array}{c}.024^{* *} \\
(.011) \\
{[0]}\end{array}$ & $\begin{array}{c}.0078 \\
(.0055) \\
{[.29]}\end{array}$ & $\begin{array}{c}-.031^{* *} \\
(.014)\end{array}$ \\
\hline $\begin{array}{l}\text { Nbhd effect } \\
\left(0.36 * \beta_{N}\right)\end{array}$ & $\begin{array}{c}.0038 \\
(.0087) \\
{[.4]}\end{array}$ & $\begin{array}{c}.0019 \\
(.0064) \\
{[0]}\end{array}$ & $\begin{array}{c}-.0051 \\
(.0043) \\
{[.34]}\end{array}$ & $\begin{array}{l}.0053 \\
(.009)\end{array}$ \\
\hline $\begin{array}{l}\text { Control Mean } \\
\text { Adjusted } R^{2} \\
\text { Observations }\end{array}$ & $\begin{array}{c}.8 \\
.016 \\
1.8 \mathrm{M}\end{array}$ & $\begin{array}{c}.1 \\
.016 \\
1.8 \mathrm{M}\end{array}$ & $\begin{array}{c}.0 \\
.030 \\
1.8 \mathrm{M}\end{array}$ & $\begin{array}{c}. \\
.013 \\
1.8 \mathrm{M}\end{array}$ \\
\hline
\end{tabular}

The unit of analysis is a household. The outcome in Columns 1-3 is the probability of having a top earner in the indicated income bracket. Estimation is via logit with marginal effects reported (Columns 1-3) and ordered logit with marginal effects on the lowest income category reported (Column 4). Standard errors in parentheses are clustered by mandal. Significance is denoted: ${ }^{*} p<.10,{ }^{* *} p<.05,{ }^{* * *} p<.01$. p-values from randomization inference on 10,000 iterations are reported in square brackets 
Table 5: Non-agricultural enterprises and employees

\begin{tabular}{|c|c|c|c|c|c|}
\hline & $\frac{\text { All sectors }}{(1)}$ & $\frac{\text { Livestock }}{(2)}$ & $\frac{\begin{array}{c}\text { Manufacturing } \\
\text { and construction }\end{array}}{(3)}$ & $\begin{array}{l}\text { Wholesale } \\
\text { and retail } \\
\frac{(4)}{4}\end{array}$ & $\frac{\text { Other }}{(5)}$ \\
\hline \multicolumn{6}{|c|}{ Panel A: Number of employees } \\
\hline $\begin{array}{l}\text { Adjusted TE } \\
\left(\beta_{T}+0.36 * \beta_{N}\right)\end{array}$ & $\begin{array}{c}3307^{* *} \\
(1554) \\
{[.089]}\end{array}$ & $\begin{array}{c}294 \\
(246) \\
{[.19]}\end{array}$ & $\begin{array}{l}909^{*} \\
(465) \\
{[.13]}\end{array}$ & $\begin{array}{l}836 \\
(554) \\
{[.15]}\end{array}$ & $\begin{array}{c}1268^{* *} \\
(616) \\
{[.12]}\end{array}$ \\
\hline $\begin{array}{l}\text { Main effect } \\
\left(\beta_{T}\right)\end{array}$ & $\begin{array}{c}2251^{* *} \\
(1101) \\
{[.1]}\end{array}$ & $\begin{array}{l}113 \\
(212) \\
{[.33]}\end{array}$ & $\begin{array}{l}588^{*} \\
(313) \\
{[.14]}\end{array}$ & $\begin{array}{c}764^{*} \\
(398) \\
{[.1]}\end{array}$ & $\begin{array}{l}786^{*} \\
(435) \\
{[.17]}\end{array}$ \\
\hline $\begin{array}{l}\text { Nbhd effect } \\
\left(0.36 * \beta_{N}\right)\end{array}$ & $\begin{array}{c}1056 \\
(826) \\
{[.2]}\end{array}$ & $\begin{array}{c}182 \\
(191) \\
{[.16]}\end{array}$ & $\begin{array}{c}320 \\
(280) \\
{[.22]}\end{array}$ & $\begin{array}{c}71 \\
(317) \\
{[.41]}\end{array}$ & $\begin{array}{c}483 \\
(339) \\
{[.2]}\end{array}$ \\
\hline Control mean & 6796.7 & 1711.5 & 1439.9 & 1219.2 & 2426.1 \\
\hline Adjusted $R^{2}$ & 0.165 & 0.518 & 0.164 & 0.115 & 0.122 \\
\hline Observations & 157 & 157 & 157 & 157 & 157 \\
\hline \multicolumn{6}{|c|}{ Panel B: Number of enterprises } \\
\hline $\begin{array}{l}\text { Adjusted TE } \\
\left(\beta_{T}+0.36 * \beta_{N}\right)\end{array}$ & $\begin{array}{l}1095^{*} \\
(575) \\
{[.085]}\end{array}$ & $\begin{array}{c}177 \\
(134) \\
{[.18]}\end{array}$ & $\begin{array}{l}167 \\
(176) \\
{[.28]}\end{array}$ & $\begin{array}{c}327 \\
(227) \\
{[.13]}\end{array}$ & $\begin{array}{l}423^{* *} \\
(214) \\
{[.093]}\end{array}$ \\
\hline $\begin{array}{l}\text { Main effect } \\
\left(\beta_{T}\right)\end{array}$ & $\begin{array}{l}856^{* *} \\
(427) \\
{[.078]}\end{array}$ & $\begin{array}{c}62 \\
(126) \\
{[.32]}\end{array}$ & $\begin{array}{l}221 \\
(141) \\
{[.14]}\end{array}$ & $\begin{array}{l}311^{*} \\
(165) \\
{[.074]}\end{array}$ & $\begin{array}{l}262 \\
(163) \\
{[.14]}\end{array}$ \\
\hline $\begin{array}{l}\text { Nbhd effect } \\
\left(0.36 * \beta_{N}\right)\end{array}$ & $\begin{array}{c}239 \\
(311) \\
{[.27]}\end{array}$ & $\begin{array}{c}115 \\
(108) \\
{[.14]}\end{array}$ & $\begin{array}{l}-54 \\
(115) \\
{[.58]}\end{array}$ & $\begin{array}{c}16 \\
(126) \\
{[.43]}\end{array}$ & $\begin{array}{l}162 \\
(120) \\
{[.17]}\end{array}$ \\
\hline Control mean & 3816.5 & 1127.3 & 754.1 & 739.3 & 1195.7 \\
\hline Adjusted $R^{2}$ & 0.285 & 0.579 & 0.211 & 0.163 & 0.245 \\
\hline Observations & 157 & 157 & 157 & 157 & 157 \\
\hline
\end{tabular}

The unit of analysis is a mandal. Outcomes are the number of employees (Panel A) and number of firms (Panel B) reported in the respective categories in the Economic Census. Standard errors in parentheses are heteroskedasticity-robust, and statistical significance based on these is denoted as: ${ }^{*} p<.10,{ }^{* *} p<.05,{ }^{* * *} p<$ .01. $p$-values from randomization inference on 10,000 iterations are reported in square brackets 
Table 6: Heterogeneous effects on days worked by land concentration

\begin{tabular}{|c|c|c|c|c|}
\hline & $\begin{array}{c}\begin{array}{c}\text { Raw HHI } \\
\text { (full sample) }\end{array} \\
\end{array}$ & $\begin{array}{c}\text { Raw HHI } \\
\text { (above } 1 \text { acre) }\end{array}$ & $\begin{array}{c}\text { Standardized } \\
\text { (full sample) }\end{array}$ & $\begin{array}{c}\text { Standardized } \\
\text { (above } 1 \text { acre) }\end{array}$ \\
\hline & (1) & $(2)$ & (3) & (4) \\
\hline Treatment & $\begin{array}{c}.46 \\
(.57) \\
\{.58\}\end{array}$ & $\begin{array}{c}.45 \\
(.57) \\
\{.58\}\end{array}$ & $\begin{array}{c}.6 \\
(.55) \\
\{.55\}\end{array}$ & $\begin{array}{c}.6 \\
(.55) \\
\{.56\}\end{array}$ \\
\hline$H^{*}$ & $\begin{array}{c}-4.7^{* *} \\
(2.1) \\
\{2.6\}\end{array}$ & $\begin{array}{c}-6.2^{*} \\
(3.2) \\
\{2.9\}\end{array}$ & $\begin{array}{c}-.56^{* *} \\
(.25) \\
\{.3\}\end{array}$ & $\begin{array}{l}-.63^{*} \\
(.33) \\
\{.3\}\end{array}$ \\
\hline Treatment $\times H^{*}$ & $\begin{array}{c}4.6^{* *} \\
(2.3) \\
\{3\}\end{array}$ & $\begin{array}{l}6.5^{*} \\
(3.4) \\
\{3.2\}\end{array}$ & $\begin{array}{l}.55^{* *} \\
(.27) \\
\{.35\}\end{array}$ & $\begin{array}{l}.66^{*} \\
(.34) \\
\{.33\}\end{array}$ \\
\hline Control Mean & 7.9 & 7.9 & 7.9 & 7.9 \\
\hline Adjusted $R^{2}$ & .019 & .020 & .019 & .020 \\
\hline Observations & 13,827 & 13,798 & 13,827 & 13,798 \\
\hline
\end{tabular}

The unit of analysis is an adult. The outcome variable is the same as Column 5 of Table 2 " " $H^{*}$ " is the Herfindahl index of land ownership in the village, and each column represents a different measure of the index; for both the full sample and a restricted sample of those who own above 1 acre, both normalized (raw) and standardized separately for treatment and control areas. Estimation is as described in Section 2.3 Standard errors in parentheses are clustered by mandal; those in brackets are spatial as in Conley (2008). Significance based on the former is denoted: ${ }^{*} p<.10,{ }^{* *} p<.05,{ }^{* * *} p<.01$.

Table 7: Assets, liabilities, and expenditure

\begin{tabular}{|c|c|c|c|c|c|}
\hline & \multicolumn{2}{|c|}{$\begin{array}{l}\text { Annualized expenditure } \\
\text { (Rs. per year) }\end{array}$} & \multirow{2}{*}{$\begin{array}{c}\text { Total savings } \\
\text { (Rs.) }\end{array}$} & \multirow{2}{*}{$\begin{array}{c}\begin{array}{c}\text { Total loans } \\
\text { (Rs.) }\end{array} \\
(4)\end{array}$} & \multirow{2}{*}{$\begin{array}{c}\text { Owns land } \\
\frac{(\%)}{(5)}\end{array}$} \\
\hline & (1) & (2) & & & \\
\hline $\begin{array}{l}\text { Adjusted TE } \\
\left(\beta_{T}+0.36 * \beta_{N}\right)\end{array}$ & $\begin{array}{c}389 \\
(4676) \\
\{4820\}\end{array}$ & $\begin{array}{c}18105 \\
(13106) \\
\{12360\}\end{array}$ & $\begin{array}{c}260 \\
(322) \\
\{370\}\end{array}$ & $\begin{array}{c}20400^{* * *} \\
(6403) \\
\{6356\}\end{array}$ & $\begin{array}{l}.072^{* *} \\
(.033) \\
\{.033\}\end{array}$ \\
\hline $\begin{array}{l}\text { Main effect } \\
\left(\beta_{T}\right)\end{array}$ & $\begin{array}{l}-1028 \\
(3893) \\
\{3692\}\end{array}$ & $\begin{array}{l}16417^{*} \\
(8866) \\
\{9532\}\end{array}$ & $\begin{array}{c}41 \\
(279) \\
\{303\}\end{array}$ & $\begin{array}{l}11237^{* *} \\
(4912) \\
\{4656\}\end{array}$ & $\begin{array}{l}.056^{* *} \\
(.025) \\
\{.024\}\end{array}$ \\
\hline $\begin{array}{l}\text { Nbhd effect } \\
\left(0.36 * \beta_{N}\right)\end{array}$ & $\begin{array}{l}1416 \\
(2642) \\
\{2646\}\end{array}$ & $\begin{array}{c}1687 \\
(7599) \\
\{6735\}\end{array}$ & $\begin{array}{c}219 \\
(157) \\
\{183\}\end{array}$ & $\begin{array}{l}9163^{* * *} \\
(3308) \\
\{3441\}\end{array}$ & $\begin{array}{l}.016 \\
(.018) \\
\{.018\}\end{array}$ \\
\hline Survey & NREGA & NSS & NREGA & NREGA & NREGA \\
\hline Control mean & $85,030.7$ & $58,779.1$ & $2,966.1$ & $68,107.7$ & .6 \\
\hline Adjusted $R^{2}$ & .014 & .080 & .018 & .013 & .031 \\
\hline Observations & 4,827 & 222 & 4,808 & 4,840 & 4,836 \\
\hline
\end{tabular}

The unit of analysis is a household. "Total savings" is current cash savings. "Total loans" is the total outstanding principal of the household's five largest active loans. "Owns land (\%)" is an indicator for whether a household owns any land. "Annualized Expenditure (Rs. per year)" is the household's estimated annual expenditure. Estimation is as described in Section 2.3. Appendices $\mathrm{C}$ and $\mathrm{B}$ discuss recall and sensitivity to outliers in more detail. Standard errors in parentheses are clustered by mandal; those in brackets are spatial as in Conley (2008). Significance based on the former is denoted: ${ }^{*} p<.10,{ }^{* *} p<.05,{ }^{* * *} p<.01$. 
Figure 1: Seasonality in NREGS and labor market outcomes
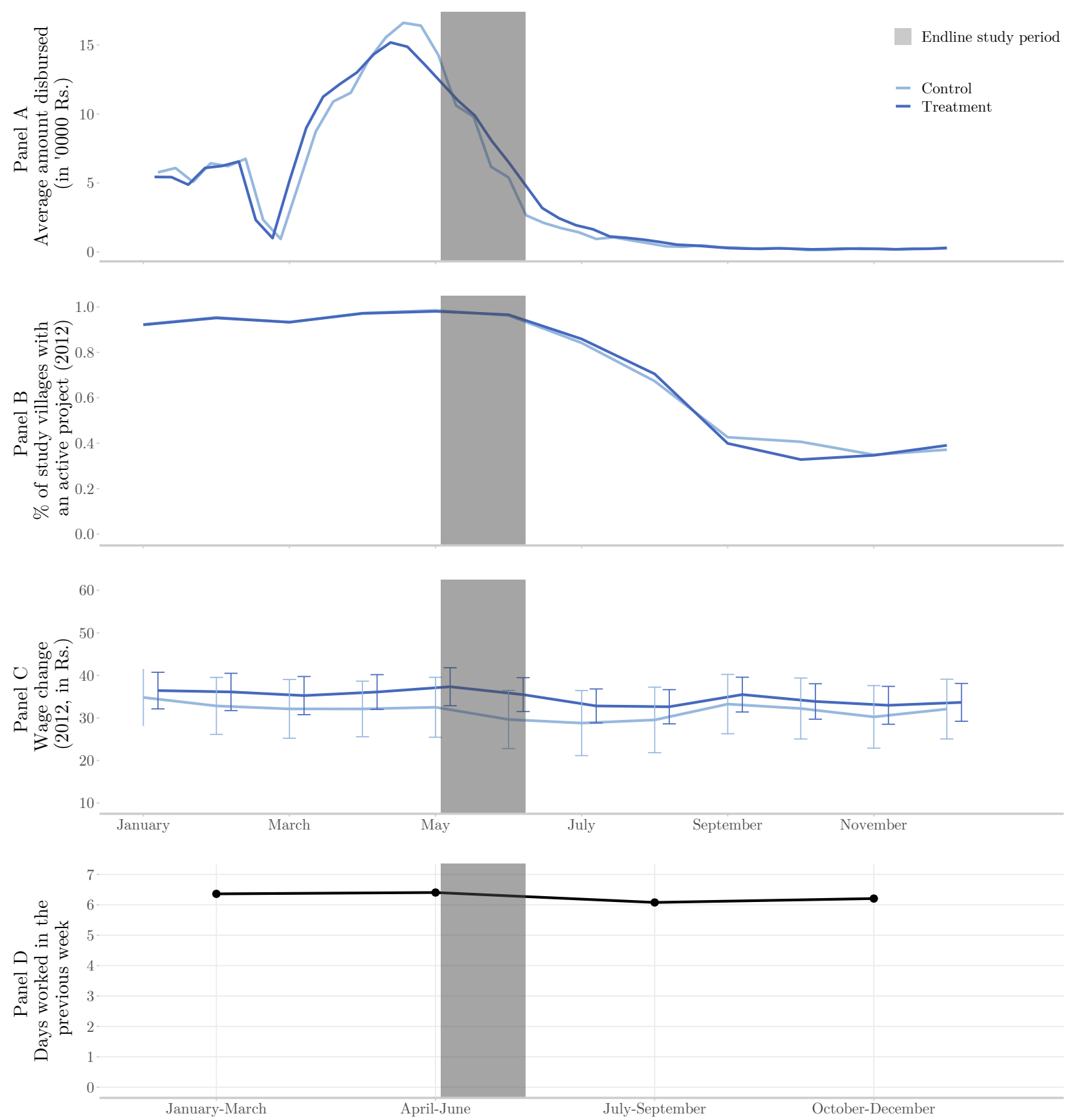

Panel A (reproduced from Muralidharan et al. (2016)) shows official NREGS payments for all workers averaged at the village-week level for treatment and control areas. Panel B plots the proportion of study villages with at least one active NREGS project. We measure NREGS project activity using muster roll data from 2012 and define a village as having an active project if any work was reported in that village during that month. Panel $\mathrm{C}$ plots the average change in agricultural wages between baseline and endline. We plot the adjusted treatment effect on (changes in) agricultural wages using surveys of prominent figures in each village and weight these by (inverse) village sampling probabilities. Confidence intervals are based on standard errors clustered at the mandal level. The grey band denotes the endline study period, June 2012, on which our survey questions focus. Each of the first three panels are disaggregated by month and treatment status. Panel D captures seasonal (i.e. pooled three-month periods) variation in the average number of days worked either through wage employment or self-employment (excluding NREGA work) in the previous week using data pooled from the 66th (2009-2010) and 68th (2011-2012) rounds of the National Sample Survey (NSS). 
Figure 2: Estimated wage and profit effects by landholding
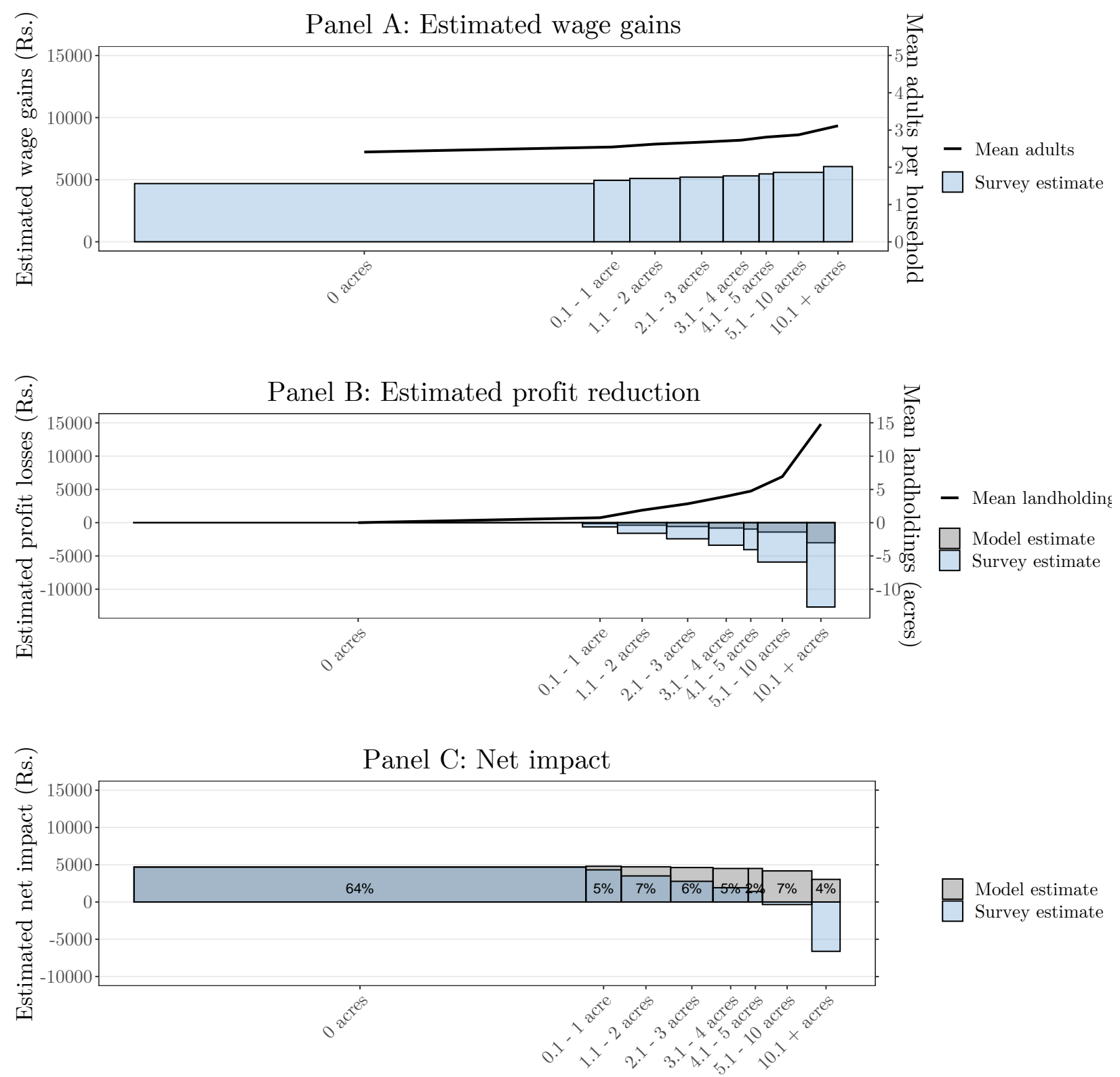

Landholding bin

Panel A uses SECC microdata to show the fraction of laborers per household for each discrete interval across the landholding distribution (black line, right-hand axis). The blue bars and left-hand axis show the estimated wage gains when we apply the treatment effect estimated in our survey data to the distribution of laborers. Panel B shows both the mean landholding size in acres for each bin plus two estimates of profit losses (derived from our survey estimates and model-based estimates). Panel 3 shows the net impact, calculated by summing the estimated wage gains with the two estimated profit losses. Percentages indicate the share of the population in each landholding bin. A full description of the methods used is in Appendix H. 


\section{A Additional outcomes}

Table A.1: Days of NREGS work provided

(1)

\begin{tabular}{lcc}
\hline Adjusted TE & 913 & 1071 \\
$\left(\beta_{T}+0.36 * \beta_{N}\right)$ & $(772)$ & $(873)$ \\
& $\{788\}$ & $\{935\}$ \\
Main effect & 637 & 546 \\
$\left(\beta_{T}\right)$ & $(641)$ & $(753)$ \\
& $\{606\}$ & $\{32\}$ \\
Nbhd effect & 276 & 525 \\
$\left(0.36 * \beta_{N}\right)$ & $(356)$ & $(361)$ \\
& $\{365\}$ & $\{389\}$ \\
\hline Baseline lag & Yes & No \\
Control mean & $6,605.2$ & $6,605.2$ \\
Adjusted $R^{2}$ & .324 & .113 \\
Observations & 856 & 861 \\
\hline
\end{tabular}

The unit of analysis is a village. Data comes from official NREGS administrative records on the number of days of NREGS work provided for each NREGS project. Estimation is as described in Section 2.3. Standard errors in parentheses are clustered by mandal; those in brackets are spatial as in Conley (2008). Significance based on the former is denoted: ${ }^{*} p<.10,{ }^{* *} p<.05,{ }^{* * *} p<.01$. 
Table A.2: Baseline balance in administrative data

\begin{tabular}{|c|c|c|c|c|}
\hline & $\frac{\text { Treatment }}{(1)}$ & $\frac{\text { Control }}{(2)}$ & $\frac{\text { Difference }}{(3)}$ & $\frac{p \text {-value }}{(4)}$ \\
\hline \multicolumn{5}{|c|}{ Panel A: Official records from GoAP in 2010} \\
\hline$\%$ population working & .53 & .52 & .0062 & .47 \\
\hline$\%$ male & .51 & .51 & .00023 & .82 \\
\hline$\%$ literate & .45 & .45 & .0043 & .65 \\
\hline$\% \mathrm{SC}$ & .19 & .19 & .0025 & .81 \\
\hline$\% \mathrm{ST}$ & .1 & .12 & -.016 & .42 \\
\hline Jobcards per capita & .54 & .55 & -.0098 & .63 \\
\hline Pensions per capita & .12 & .12 & .0015 & .69 \\
\hline$\%$ old age pensions & .48 & .49 & -.012 & .11 \\
\hline$\%$ weaver pensions & .0088 & .011 & -.0018 & .63 \\
\hline$\%$ disabled pensions & .1 & .1 & .0012 & .72 \\
\hline$\%$ widow pensions & .21 & .2 & .013 & .039 \\
\hline \multicolumn{5}{|l|}{ Panel B: 2011 census rural totals } \\
\hline Population & 45580 & 45758 & -221 & .91 \\
\hline$\%$ population under age 6 & .11 & .11 & -.00075 & .65 \\
\hline$\%$ agricultural laborers & .23 & .23 & -.0049 & .59 \\
\hline$\%$ female agricultural laborers & .12 & .12 & -.0032 & .52 \\
\hline$\%$ marginal agricultural laborers & .071 & .063 & .0081 & .14 \\
\hline \multicolumn{5}{|l|}{ Panel C: 2011 census village directory } \\
\hline \# primary schools per village & 3.2 & 3.6 & -.4 & .23 \\
\hline$\%$ village with medical facility & .52 & .49 & .028 & .53 \\
\hline$\%$ villages with tap water & .87 & .84 & .033 & .25 \\
\hline$\%$ villages with banking facility & .12 & .15 & -.036 & .025 \\
\hline$\%$ villages with paved road access & .95 & .94 & .0086 & .49 \\
\hline Avg. village size in acres & 1374 & 1505 & -131 & .36 \\
\hline
\end{tabular}

This table, adapted from Muralidharan et al. (2016), compares official data on baseline characteristics across treatment and control mandals. Column 3 reports the estimate for the treatment indicator from a simple regression of the outcome with district fixed effects as the only controls; Column 4 reports the $p$-value for this estimate. A "jobcard" is a household level official enrollment document for the NREGS program. "SC" ("ST") refers to Scheduled Castes (Tribes). "Old age", "weaver", "disabled" and "widow" are different eligibility groups within the SSP administration. "Working" is defined as the participation in any economically productive activity with or without compensation, wages or profit. "Main" workers are defined as those who engaged in any economically productive work for more than 183 days in a year. "Marginal" workers are those for whom the period they engaged in economically productive work does not exceed 182 days. The last set of variables is taken from 2011 census village directory which records information about various facilities within a census village (the census level of observation). "\# primary schools per village" and "Avg. village size in acres" are simple mandal averages (others are simple percentages) of the respective variable. Sampling weights are not applicable as all villages within a mandal are used. Statistical significance is denoted as: ${ }^{*} p<.10,{ }^{* *} p<.05,{ }^{* * *} p<.01$. 
Table A.3: Baseline balance in survey data

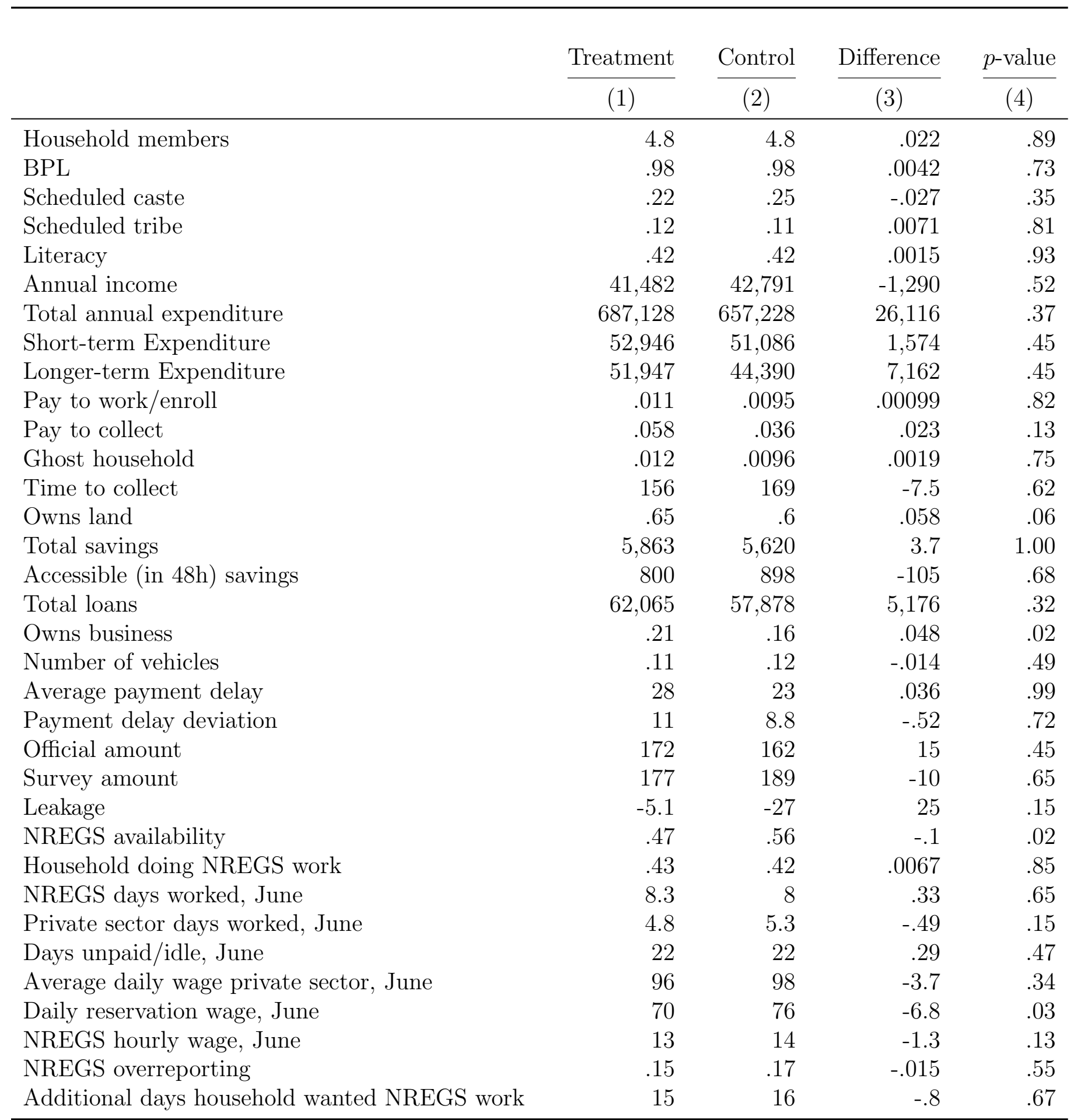

This table compares baseline characteristics across treatment and control mandals from our survey data. Column 3 reports the estimate for the treatment indicator from a simple regression of the outcome with district fixed effects as the only controls; Column 4 reports the $p$-value for this estimate. "BPL" is an indicator for households below the poverty line. "Accessible (in 48h) savings" is the amount of savings a household could access within 48h. "NREGS availability" is an indicator for whether a household believes that anybody in the village could get work on NREGS when they want it. Standard errors are clustered at the mandal level. Statistical significance is denoted as: ${ }^{*} p<.10,{ }^{* *} p<.05,{ }^{* * *} p<.01$. 
Table A.4: Heterogeneous effects on income by household demographics

\begin{tabular}{|c|c|c|c|c|}
\hline & \multicolumn{4}{|c|}{ Total income (Rs.) } \\
\hline & $\begin{array}{c}(1) \\
\mathrm{HH} \text { is } \\
\mathrm{ST} \text { or } \mathrm{SC}\end{array}$ & $\begin{array}{c}(2) \\
\text { Most educated HH member } \\
\text { has below median education }\end{array}$ & $\begin{array}{l}\text { (3) } \\
\text { Head of } \mathrm{HH} \\
\text { is widow }\end{array}$ & $\begin{array}{c}\text { HH with at least } \\
1 \text { member eligible for SSP }\end{array}$ \\
\hline Main effect $[$ Covariate $=1]$ & $\begin{array}{l}10771^{* *} \\
(5145) \\
\{4401\}\end{array}$ & $\begin{array}{l}5951^{*} \\
(3322) \\
\{3202\}\end{array}$ & $\begin{array}{l}3445 \\
(8105) \\
\{8373\}\end{array}$ & $\begin{array}{l}3446 \\
(3968) \\
\{4234\}\end{array}$ \\
\hline Main effect $[$ Covariate $=0]$ & $\begin{array}{l}7830^{*} \\
(4606) \\
\{3970\}\end{array}$ & $\begin{array}{l}10947^{*} \\
(5934) \\
\{5433\}\end{array}$ & $\begin{array}{l}9671^{* *} \\
(3921) \\
\{3524\}\end{array}$ & $\begin{array}{l}13452^{* *} \\
(5403) \\
\{4517\}\end{array}$ \\
\hline$[$ Covariate $=1]$ & $\begin{array}{l}-9717^{*} \\
(5205) \\
\{4856\}\end{array}$ & $\begin{array}{c}-28260^{* * *} \\
(5022) \\
\{4833\}\end{array}$ & $\begin{array}{c}-18345^{* * *} \\
(6564) \\
\{6139\}\end{array}$ & $\begin{array}{l}-2459 \\
(4949) \\
\{4463\}\end{array}$ \\
\hline $\begin{array}{l}p \text {-val: Main effect }{ }_{1}={\text { Main } \text { effect }_{0}}_{\text {Control mean }} \\
\text { Adjusted } R^{2} \\
\text { Observations }\end{array}$ & $\begin{array}{c}0.648 \\
69122 \\
0.043 \\
4853\end{array}$ & $\begin{array}{c}0.419 \\
69122 \\
0.112 \\
4871\end{array}$ & $\begin{array}{c}0.442 \\
69122 \\
0.058 \\
4813\end{array}$ & $\begin{array}{c}0.098 \\
69122 \\
0.048 \\
4874\end{array}$ \\
\hline
\end{tabular}

The unit of analysis is a household. This table examines heterogeneous effects on income using our survey data. We test for heterogeneity along dimensions unlikely to have been affected by treatment: caste, education, and pension eligibility. Column headings define the "Covariate" variable referred to in the row headings, which differs in each column. The outcome in all columns is total annualized HH income. "HH is ST or SC" is an indicator for whether the household belongs to a Scheduled Tribe/Caste. "Most educated HH member has above median education" is an indicator for whether the most educated member of the household has an above median number of years of education. "HH fraction eligible for SSP" is the fraction of household members who identify as eligible for SSP, though they may not actually receive pension. "Head of HH is widow" is an indicator for whether the head of household is a widow. We truncate observations that are in the top .5\% percentile of total income in treatment and control groups. All regressions include the village mean of the dependent variable at baseline, district fixed effects and the first principal component of a vector of mandal characteristics used to stratify randomization. Standard errors clustered at the mandal level are in parentheses, and statistical significance based on these is denoted as: ${ }^{*} p<.10,{ }^{* *} p<.05,{ }^{* * *} p<.01$. 
Table A.5: Migration

\begin{tabular}{|c|c|c|c|c|c|}
\hline & \multirow{2}{*}{$\begin{array}{c}\begin{array}{c}\text { Not surveyed } \\
\text { because of migration }\end{array} \\
(1)\end{array}$} & \multicolumn{3}{|c|}{ Among surveyed households } & \multirow{2}{*}{$\begin{array}{c}\text { Migration common } \\
\text { in May? } \\
(5)\end{array}$} \\
\hline & & $\begin{array}{c}(2) \\
\text { Did migrate? }\end{array}$ & $\begin{array}{c}(3) \\
\text { Days migrated }\end{array}$ & $\begin{array}{c}(4) \\
\text { Household size }\end{array}$ & \\
\hline $\begin{array}{l}\text { Adjusted TE } \\
\left(\beta_{T}+0.36 * \beta_{N}\right)\end{array}$ & $\begin{array}{c}-.05 \\
(.035) \\
\{.039\}\end{array}$ & $\begin{array}{l}.038^{*} \\
(.022) \\
\{.021\}\end{array}$ & $\begin{array}{c}2.8 \\
(6.9) \\
\{6.9\}\end{array}$ & $\begin{array}{c}.06 \\
(.13) \\
\{.14\}\end{array}$ & $\begin{array}{c}.034 \\
(.048) \\
\{.047\}\end{array}$ \\
\hline $\begin{array}{l}\text { Main effect } \\
\left(\beta_{T}\right)\end{array}$ & $\begin{array}{l}-.018 \\
(.025) \\
\{.03\}\end{array}$ & $\begin{array}{c}.026 \\
(.018) \\
\{.015\}\end{array}$ & $\begin{array}{c}1.3 \\
(5.4) \\
\{5.1\}\end{array}$ & $\begin{array}{l}.053 \\
(.1) \\
\{.1\}\end{array}$ & $\begin{array}{c}.048 \\
(.038) \\
\{.036\}\end{array}$ \\
\hline $\begin{array}{l}\text { Nbhd effect } \\
\left(0.36 * \beta_{N}\right)\end{array}$ & $\begin{array}{c}-.032^{* *} \\
(.016) \\
\{.017\}\end{array}$ & $\begin{array}{c}.013 \\
(.01) \\
\{.011\}\end{array}$ & $\begin{array}{c}1.5 \\
(2.4) \\
\{2.5\}\end{array}$ & $\begin{array}{c}.0067 \\
(.08) \\
\{.076\}\end{array}$ & $\begin{array}{l}-.014 \\
(.023) \\
\{.023\}\end{array}$ \\
\hline Unit of observation & Household & Household & Household & Household & GP \\
\hline Control mean & .08 & .08 & 15.95 & 4.25 & .21 \\
\hline Adjusted $R^{2}$ & .026 & .029 & .016 & .019 & .453 \\
\hline Observations & 5,183 & 4,822 & 4,858 & 4,858 & 799 \\
\hline
\end{tabular}

Columns 1-4 use data from our household survey, and Column 5 uses data from a separate survey of village elders. "Not surveyed because of migration" is an indicator for whether we could not survey a household because they had migrated. "Did migrate?" is an indicator for whether any household member stayed away from home for the purpose of work during the last year. "Days migrated" is the sum of all days any household member stayed away from home for work. "Household size" is the number of household members. "Migration common in May?" is an indicator for whether it was common for workers to migrate out of the village in search of work during the month of May since the implementation of NREGS. Estimation is as described in Section 2.3. Standard errors in parentheses are clustered by mandal; those in brackets are spatial as in Conley (2008). Significance based on the former is denoted: ${ }^{*} p<.10,{ }^{* *} p<.05,{ }^{* * *} p<.01$. 
Table A.6: Firm size counts and employee counts by firm size

\begin{tabular}{|c|c|c|c|c|c|}
\hline & $\frac{\text { One employee }}{(1)}$ & $\frac{\text { Two employees }}{(2)}$ & $\begin{array}{c}\begin{array}{c}\text { Three to five } \\
\text { employees }\end{array} \\
(3)\end{array}$ & $\frac{\begin{array}{l}\text { Six to ten } \\
\text { employees }\end{array}}{(4)}$ & $\begin{array}{c}\begin{array}{c}\text { More than } \\
\text { ten employees }\end{array} \\
(5)\end{array}$ \\
\hline $\begin{array}{l}\text { Panel A: Number } \\
\text { Adjusted TE } \\
\left(\beta_{T}+0.36 * \beta_{N}\right)\end{array}$ & $\begin{array}{l}555^{*} \\
(302)\end{array}$ & $\begin{array}{c}130 \\
(164)\end{array}$ & $\begin{array}{c}88 \\
(112)\end{array}$ & $\begin{array}{c}14 \\
(57)\end{array}$ & $\begin{array}{c}13 \\
(8.1)\end{array}$ \\
\hline $\begin{array}{l}\text { Main effect } \\
\left(\beta_{T}\right)\end{array}$ & $\begin{array}{l}412^{*} \\
(228)\end{array}$ & $\begin{array}{c}209 \\
(148)\end{array}$ & $\begin{array}{c}191 \\
(116)\end{array}$ & $\begin{array}{c}94 \\
(64)\end{array}$ & $\begin{array}{l}13^{* *} \\
(5.6)\end{array}$ \\
\hline $\begin{array}{l}\text { Nbhd effect } \\
\left(0.36 * \beta_{N}\right)\end{array}$ & $\begin{array}{c}144 \\
(232)\end{array}$ & $\begin{array}{l}-79 \\
(100)\end{array}$ & $\begin{array}{l}-103 \\
(73)\end{array}$ & $\begin{array}{l}-80 \\
(77)\end{array}$ & $\begin{array}{l}-.19 \\
(4.7)\end{array}$ \\
\hline $\begin{array}{l}\text { Control mean } \\
\text { Adjusted } R^{2} \\
\text { Observations }\end{array}$ & $\begin{array}{c}2094.2 \\
0.28 \\
157\end{array}$ & $\begin{array}{c}1290.4 \\
0.33 \\
157\end{array}$ & $\begin{array}{c}297.6 \\
0.09 \\
157\end{array}$ & $\begin{array}{l}56.1 \\
0.05 \\
157\end{array}$ & $\begin{array}{l}16.7 \\
0.08 \\
157\end{array}$ \\
\hline $\begin{array}{l}\text { Panel B: Number } \\
\text { Adjusted TE } \\
\left(\beta_{T}+0.36 * \beta_{N}\right)\end{array}$ & $\begin{array}{l}\text { ployees } \\
611^{* *} \\
(292)\end{array}$ & $\begin{array}{c}332 \\
(323)\end{array}$ & $\begin{array}{c}359 \\
(430)\end{array}$ & $\begin{array}{c}82 \\
(404)\end{array}$ & $\begin{array}{l}623^{*} \\
(316)\end{array}$ \\
\hline $\begin{array}{l}\text { Main effect } \\
\left(\beta_{T}\right)\end{array}$ & $\begin{array}{l}492^{* *} \\
(237)\end{array}$ & $\begin{array}{l}502^{*} \\
(293)\end{array}$ & $\begin{array}{l}736^{*} \\
(429)\end{array}$ & $\begin{array}{c}611 \\
(421)\end{array}$ & $\begin{array}{l}503^{* *} \\
(221)\end{array}$ \\
\hline $\begin{array}{l}\text { Nbhd effect } \\
\left(0.36 * \beta_{N}\right)\end{array}$ & $\begin{array}{c}119 \\
(224)\end{array}$ & $\begin{array}{l}-170 \\
(190)\end{array}$ & $\begin{array}{l}-377 \\
(276)\end{array}$ & $\begin{array}{l}-528 \\
(516)\end{array}$ & $\begin{array}{c}120 \\
(164)\end{array}$ \\
\hline $\begin{array}{l}\text { Control mean } \\
\text { Adjusted } R^{2} \\
\text { Observations }\end{array}$ & $\begin{array}{c}2094.2 \\
0.32 \\
157\end{array}$ & $\begin{array}{c}2580.9 \\
0.34 \\
157\end{array}$ & $\begin{array}{c}1046.9 \\
0.08 \\
157\end{array}$ & $\begin{array}{c}389.8 \\
0.05 \\
157\end{array}$ & $\begin{array}{l}574.3 \\
0.08 \\
157\end{array}$ \\
\hline
\end{tabular}

The unit of analysis is a mandal. Outcomes are the number of firms (Panel A) and number of employees (Panel B) reported in the respective categories in the Economic Census. Standard errors in parentheses are heteroskedasticity-robust, and statistical significance based on these is denoted as: ${ }^{*} p<.10,{ }^{* *} p<.05,{ }^{* * *} p<.01$. 
Table A.7: SECC treatment effect decomposition

\begin{tabular}{|c|c|c|c|c|c|c|c|}
\hline & & \multicolumn{3}{|c|}{ Beneficiaries } & \multicolumn{3}{|c|}{ Non-beneficiaries } \\
\hline & & $\begin{array}{c}\text { (1) } \\
\text { Lowest } \\
\text { bracket }\end{array}$ & $\begin{array}{c}(2) \\
\text { Middle } \\
\text { bracket }\end{array}$ & $\begin{array}{c}(3) \\
\text { Highest } \\
\text { bracket }\end{array}$ & $\begin{array}{l}\text { (4) } \\
\text { Lowest } \\
\text { bracket }\end{array}$ & $\begin{array}{l}(5) \\
\text { Middle } \\
\text { bracket }\end{array}$ & $\begin{array}{l}(6) \\
\text { Highest } \\
\text { bracket }\end{array}$ \\
\hline \multirow[t]{3}{*}{$\mathrm{S}=75 \%$} & $\begin{array}{l}\text { Adjusted TE } \\
\left(\beta_{T}+0.36 * \beta_{N}\right)\end{array}$ & $\begin{array}{l}-.061^{*} \\
(.034)\end{array}$ & $\begin{array}{l}.039 \\
(.028)\end{array}$ & $\begin{array}{l}.019^{* *} \\
(.0096)\end{array}$ & $\begin{array}{l}.005 \\
(.038)\end{array}$ & $\begin{array}{l}.013 \\
(.032)\end{array}$ & $\begin{array}{l}-.015 \\
(.012)\end{array}$ \\
\hline & $\begin{array}{l}\text { Main effect } \\
\left(\beta_{T}\right)\end{array}$ & $\begin{array}{l}-.06^{* *} \\
(.027)\end{array}$ & $\begin{array}{l}.037 \\
(.023)\end{array}$ & $\begin{array}{l}.02^{* *} \\
(.0084)\end{array}$ & $\begin{array}{l}-.002 \\
(.03)\end{array}$ & $\begin{array}{l}.011 \\
(.026)\end{array}$ & $\begin{array}{l}-.005 \\
(.01)\end{array}$ \\
\hline & $\begin{array}{l}\text { Nbhd effect } \\
\left(0.36 * \beta_{N}\right)\end{array}$ & $\begin{array}{l}-.001 \\
(.018)\end{array}$ & $\begin{array}{l}.0024 \\
(.014)\end{array}$ & $\begin{array}{l}-.0013 \\
(.0069)\end{array}$ & $\begin{array}{l}.008 \\
(.02)\end{array}$ & $\begin{array}{l}.002 \\
(.015)\end{array}$ & $\begin{array}{l}-.01 \\
(.008)\end{array}$ \\
\hline \multirow[t]{3}{*}{$\begin{array}{l}\mathrm{S}=65 \% \\
\text { (Main specification) }\end{array}$} & $\begin{array}{l}\text { Adjusted TE } \\
\left(\beta_{T}+0.36 * \beta_{N}\right)\end{array}$ & $\begin{array}{c}-.053^{* *} \\
(.025)\end{array}$ & $\begin{array}{l}.035 \\
(.021)\end{array}$ & $\begin{array}{l}.016^{* *} \\
(.0082)\end{array}$ & $\begin{array}{l}-.003 \\
(.03)\end{array}$ & $\begin{array}{l}.017 \\
(.026)\end{array}$ & $\begin{array}{l}-.012 \\
(.011)\end{array}$ \\
\hline & $\begin{array}{l}\text { Main effect } \\
\left(\beta_{T}\right)\end{array}$ & $\begin{array}{c}-.052^{* * *} \\
(.02)\end{array}$ & $\begin{array}{l}.035^{* *} \\
(.017)\end{array}$ & $\begin{array}{l}.016^{* *} \\
(.0067)\end{array}$ & $\begin{array}{l}-.01 \\
(.024)\end{array}$ & $\begin{array}{l}.013 \\
(.021)\end{array}$ & $\begin{array}{l}-.001 \\
(.009)\end{array}$ \\
\hline & $\begin{array}{l}\text { Nbhd effect } \\
\left(0.36 * \beta_{N}\right)\end{array}$ & $\begin{array}{c}-.00043 \\
(.015)\end{array}$ & $\begin{array}{c}-.00018 \\
(.012)\end{array}$ & $\begin{array}{l}.00067 \\
(.0055)\end{array}$ & $\begin{array}{l}.008 \\
(.017)\end{array}$ & $\begin{array}{l}.004 \\
(.014)\end{array}$ & $\begin{array}{r}-.012 \\
(.007)\end{array}$ \\
\hline \multirow[t]{3}{*}{$\mathrm{S}=55 \%$} & $\begin{array}{l}\text { Adjusted TE } \\
\left(\beta_{T}+0.36 * \beta_{N}\right)\end{array}$ & $\begin{array}{l}-.038^{*} \\
(.019)\end{array}$ & $\begin{array}{l}.026 \\
(.017)\end{array}$ & $\begin{array}{l}.01^{*} \\
(.0061)\end{array}$ & $\begin{array}{l}-.018 \\
(.025)\end{array}$ & $\begin{array}{l}.026 \\
(.023)\end{array}$ & $\begin{array}{l}-.006 \\
(.009)\end{array}$ \\
\hline & $\begin{array}{l}\text { Main effect } \\
\left(\beta_{T}\right)\end{array}$ & $\begin{array}{c}-.039^{* *} \\
(.016)\end{array}$ & $\begin{array}{l}.026^{*} \\
(.013)\end{array}$ & $\begin{array}{l}.012^{* *} \\
(.0051)\end{array}$ & $\begin{array}{l}-.023 \\
(.021)\end{array}$ & $\begin{array}{l}.022 \\
(.018)\end{array}$ & $\begin{array}{c}.003 \\
(.008)\end{array}$ \\
\hline & $\begin{array}{l}\text { Nbhd effect } \\
\left(0.36 * \beta_{N}\right)\end{array}$ & $\begin{array}{l}.0016 \\
(.012)\end{array}$ & $\begin{array}{l}.00055 \\
(.0096)\end{array}$ & $\begin{array}{l}-.0021 \\
(.0042)\end{array}$ & $\begin{array}{l}.006 \\
(.015)\end{array}$ & $\begin{array}{l}.003 \\
(.012)\end{array}$ & $\begin{array}{r}-.009 \\
(.006)\end{array}$ \\
\hline
\end{tabular}

The unit of analysis is a household. Outcomes are income brackets as defined in Table 4 . Each panel reports results for a different assumption about the share $\mathrm{S}$ of income earned by the highest-earning member of the household. Standard errors in parentheses are clustered by mandal. Significance is denoted: ${ }^{*} p<.10,{ }^{* *} p<.05,{ }^{* * *} p<.01$. 
Table A.8: Land utilization and irrigation

\begin{tabular}{|c|c|c|c|c|c|c|}
\hline & Irrigated land & Total land & Total fallows & $\begin{array}{c}\text { Non-agricultural } \\
\text { use }\end{array}$ & Net area sown & $\begin{array}{l}\text { Net area } \\
\text { irrigated }\end{array}$ \\
\hline & (1) & (2) & (3) & (4) & (5) & (6) \\
\hline $\begin{array}{l}\text { Adjusted TE } \\
\left(\beta_{T}+0.36 * \beta_{N}\right)\end{array}$ & $\begin{array}{l}-.072 \\
(.053)\end{array}$ & $\begin{array}{l}-.51^{*} \\
(.26)\end{array}$ & $\begin{array}{c}.64 \\
(1.2)\end{array}$ & $\begin{array}{l}-4^{*} \\
(2.3)\end{array}$ & $\begin{array}{l}1.1 \\
(2.1)\end{array}$ & $\begin{array}{l}-.0042 \\
(.0097)\end{array}$ \\
\hline $\begin{array}{l}\text { Main effect } \\
\left(\beta_{T}\right)\end{array}$ & $\begin{array}{c}-.087^{* *} \\
(.04)\end{array}$ & $\begin{array}{l}-.54^{*} \\
(.29)\end{array}$ & $\begin{array}{l}-.38 \\
(1.1)\end{array}$ & $\begin{array}{l}-1.8 \\
(1.6)\end{array}$ & $\begin{array}{c}.99 \\
(1.6)\end{array}$ & $\begin{array}{l}.0032 \\
(.008)\end{array}$ \\
\hline $\begin{array}{l}\text { Nbhd effect } \\
\left(0.36 * \beta_{N}\right)\end{array}$ & $\begin{array}{l}.016 \\
(.024)\end{array}$ & $\begin{array}{c}.03 \\
(.12)\end{array}$ & $\begin{array}{l}1^{*} \\
(.56)\end{array}$ & $\begin{array}{c}-2.2^{* * *} \\
(.83)\end{array}$ & $\begin{array}{l}.061 \\
(.94)\end{array}$ & $\begin{array}{l}-.0074 \\
(.0058)\end{array}$ \\
\hline Unit of observations & Household & Household & Mandal & Mandal & Mandal & Mandal \\
\hline Baseline lag & No & No & Yes & Yes & Yes & Yes \\
\hline Data Source & SECC & SECC & DSH & $\mathrm{DSH}$ & $\mathrm{DSH}$ & $\mathrm{DSH}$ \\
\hline Control mean & 7.2 & 11.0 & 10.4 & 8.8 & 26.7 & .2 \\
\hline Adjusted $R^{2}$ & .016 & .022 & .660 & .625 & .891 & .848 \\
\hline Observations & $1,726,194$ & $1,724,960$ & 851 & 845 & 845 & 851 \\
\hline
\end{tabular}

This table reports estimated treatment effects on measures of land utilization using data from the Socioeconomic and Caste Census (Columns 1-2) and from the annual District Statistical Handbooks (DSH) 2012-2013 (Columns 3-6). The DSH contains incomplete data for three mandals, leaving us with 154 out of our 157 study mandals. In Columns 1-2 the units are acres of land; "Irrigated land" is the amount in acres of land owned with assured irrigation for two crops, and "Total land" is the total amount of land owned, including both irrigated and unirrigated land. In Columns 3-6 the units are percentage of total mandal area. "Total fallows" is the total area which at one point was taken up or could be taken up for cultivation but is currently left fallow, and is equal to the sum of "current fallows" (cropped area which is kept fallow in the current year), "other fallows" (land which is has been left fallow for more than 1 year but less than 5 years) and "culturable waste" (land available which has been left fallow for the more than 5 years but would be available for cultivation). "Non-agricultural use" is land occupied by buildings, roads, railways or under water. "Net area sown" is total area sown with crops and orchards. "Net area irrigated" is the total area irrigated through any source. All regressions include district fixed effects and the first principal component of a vector of mandal characteristics used to stratify randomization. Columns 1-2 also include household-level control variables (age of the household head, an indicator for whether the head is illiterate, and and indicator for whether the household belongs to a Scheduled Caste or Tribe), and Columns 3-6 also include the lag of the dependant variables from the 2009-2010 DSH. Standard errors in parentheses are heteroskedasticity-robust and in Columns 1-2 are clustered at the mandal level. Statistical significance based on these is denoted as: ${ }^{*} p<.10,{ }^{* *} p<.05,{ }^{* * *} p<.01$. 
Table A.9: Types of NREGS labor performed

\begin{tabular}{|c|c|c|c|c|c|}
\hline & $\frac{\text { Manual labor }}{(1)}$ & $\begin{array}{l}\text { Field or technical } \\
\text { mate or assistant }\end{array}$ & $\frac{\text { Administrative tasks }}{(3)}$ & $\frac{\text { Childcare }}{(4)}$ & $\begin{array}{c}\text { Other } \\
(5)\end{array}$ \\
\hline $\begin{array}{l}\text { Adjusted TE } \\
\left(\beta_{T}+0.36 * \beta_{N}\right)\end{array}$ & $\begin{array}{l}.0022 \\
(.0089) \\
.0087\}\end{array}$ & $\begin{array}{l}.001 \\
(.0089) \\
\{.0086\}\end{array}$ & $\begin{array}{l}-.00019 \\
(.00024) \\
\{.00025\}\end{array}$ & $\begin{array}{l}-.000087 \\
(.000095) \\
\{.00011\}\end{array}$ & $\begin{array}{l}.0014 \\
(.0016) \\
\{.0016\}\end{array}$ \\
\hline $\begin{array}{l}\text { Main effect } \\
\left(\beta_{T}\right)\end{array}$ & $\begin{array}{l}-.0051 \\
(.0063) \\
\{.0062\}\end{array}$ & $\begin{array}{l}.003 \\
(.006) \\
\{.006\}\end{array}$ & $\begin{array}{l}-.00021 \\
(.00028) \\
\{.00028\}\end{array}$ & $\begin{array}{l}-.00022 \\
(.00021) \\
\{.00022\}\end{array}$ & $\begin{array}{l}.0025 \\
(.0024) \\
\{.0024\}\end{array}$ \\
\hline $\begin{array}{l}\text { Nbhd effect } \\
\left(0.36 * \beta_{N}\right)\end{array}$ & $\begin{array}{l}.0029 \\
(.0048) \\
\{.0048\} \\
\end{array}$ & $\begin{array}{l}-.002 \\
(.0045) \\
\{.0045\} \\
\end{array}$ & $\begin{array}{c}.000016 \\
(.000072) \\
\{.000079\} \\
\end{array}$ & $\begin{array}{l}.00014 \\
(.00013) \\
\{.00012\}\end{array}$ & $\begin{array}{l}-.0011 \\
(.0014) \\
\{.0015\} \\
\end{array}$ \\
\hline $\begin{array}{l}\text { Control mean } \\
\text { Adjusted } R^{2} \\
\text { Observations }\end{array}$ & $\begin{array}{c}1 \\
.004 \\
10,374\end{array}$ & $\begin{array}{c}0 \\
.003 \\
10,374\end{array}$ & $\begin{array}{c}0 \\
-.000 \\
10,374\end{array}$ & $\begin{array}{c}0 \\
.000 \\
10,374\end{array}$ & $\begin{array}{c}0 \\
.008 \\
10,374\end{array}$ \\
\hline
\end{tabular}

The unit of analysis is an adult. Estimation is as described in Section 2.3. Standard errors in parentheses are clustered by mandal; those in brackets are spatial as in Conley (2008). Significance based on the former is denoted: ${ }^{*} p<.10,{ }^{* *} p<$ $.05,{ }^{* * *} p<.01$. 
Table A.10: Land concentration indicies

\begin{tabular}{|c|c|c|c|c|}
\hline & \multicolumn{2}{|c|}{ Full sample } & \multicolumn{2}{|c|}{$\begin{array}{l}\text { Restricted to } \\
\text { above } 1 \text { acre }\end{array}$} \\
\hline & (1) & $(2)$ & $(3)$ & $(4)$ \\
\hline & Absolute & $\begin{array}{l}\text { Standardized within } \\
\text { treatment and control }\end{array}$ & Absolute & $\begin{array}{l}\text { Standardized within } \\
\text { treatment and control }\end{array}$ \\
\hline \multirow{3}{*}{$\begin{array}{l}\text { Adjusted TE } \\
\left(\beta_{T}+0.36 * \beta_{N}\right)\end{array}$} & -.018 & -.14 & -.0098 & -.076 \\
\hline & $(.018)$ & $(.15)$ & $(.011)$ & $(.11)$ \\
\hline & $\{.013\}$ & $\{.11\}$ & $\{.011\}$ & $\{.1\}$ \\
\hline \multirow{3}{*}{$\begin{array}{l}\text { Main effect } \\
\left(\beta_{T}\right)\end{array}$} & -.0045 & -.025 & -.0034 & -.012 \\
\hline & $(.011)$ & $(.098)$ & $(.0081)$ & $(.081)$ \\
\hline & $\{.0094\}$ & $\{.081\}$ & $\{.0083\}$ & $\{.083\}$ \\
\hline \multirow{3}{*}{$\begin{array}{l}\text { Nbhd effect } \\
\left(0.36 * \beta_{N}\right)\end{array}$} & -.013 & -.11 & -.0064 & -.064 \\
\hline & $(.0084)$ & $(.073)$ & $(.0053)$ & $(.054)$ \\
\hline & $\{.0062\}$ & $\{.055\}$ & $\{.005\}$ & $\{.051\}$ \\
\hline Control Mean & .0 & .0 & .0 & .0 \\
\hline Adjusted $R^{2}$ & .015 & .014 & .008 & .008 \\
\hline Observations & 837 & 837 & 835 & 835 \\
\hline
\end{tabular}

The unit of analysis is a household. The outcomes are measures of land concentration constructed using HerfindahlHirschman indices (HHI). In Columns 1 and 2 we construct these indices using data on all landholders, while in Columns 3-4 we restrict to landholders who own more than 1 acre. In Columns 1 and 3 we use absolute values of the HHI, while in Columns 2 and 4 we use the HHI normalized to have mean 0 and standard deviation 1 separately within treatment and control groups. All regressions include district fixed effects and the first principal component of a vector of mandal characteristics used to stratify randomization. Standard errors clustered at the mandal level in parentheses, and statistical significance based on these is denoted as: ${ }^{*} p<.10,{ }^{* *} p<.05,{ }^{* * *} p<.01$. 
Table A.11: Heterogenous effects on wages by landholding concentration

\begin{tabular}{|c|c|c|c|c|c|c|c|c|}
\hline & \multicolumn{4}{|c|}{ Reservation wage } & \multicolumn{4}{|c|}{ Wage realization } \\
\hline & $\begin{array}{c}(1) \\
\text { Raw HHI } \\
\text { (full sample) }\end{array}$ & $\begin{array}{c}(2) \\
\text { Raw HHI } \\
(1 \text { acre })\end{array}$ & $\begin{array}{c}\text { (3) } \\
\text { Std. HHI } \\
\text { (full sample) }\end{array}$ & $\begin{array}{c}(4) \\
\text { Std. HHI } \\
(1 \text { acre })\end{array}$ & $\begin{array}{c}(5) \\
\text { Raw HHI } \\
\text { (full sample) }\end{array}$ & $\begin{array}{c}(6) \\
\text { Raw HHI } \\
(1 \text { acre })\end{array}$ & $\begin{array}{c}(7) \\
\text { Std. HHI } \\
\text { (full sample) }\end{array}$ & $\begin{array}{l}(8) \\
\text { Std. HHI } \\
(1 \text { acre })\end{array}$ \\
\hline Treatment & $\begin{array}{c}5.3 \\
(3.5) \\
\{3.5\}\end{array}$ & $\begin{array}{c}5 \\
(3.5) \\
\{3.5\}\end{array}$ & $\begin{array}{c}4.9 \\
(3.4) \\
\{3.4\}\end{array}$ & $\begin{array}{c}5 \\
(3.4) \\
\{3.5\}\end{array}$ & $\begin{array}{c}6.5 \\
(4.6) \\
\{4.3\}\end{array}$ & $\begin{array}{c}6 \\
(4.5) \\
\{4.3\}\end{array}$ & $\begin{array}{c}6 \\
(4.4) \\
\{4.2\}\end{array}$ & $\begin{array}{c}6.2 \\
(4.4) \\
\{4.2\}\end{array}$ \\
\hline$H^{*}$ & $\begin{array}{c}3.5 \\
(6) \\
\{7.1\}\end{array}$ & $\begin{array}{l}-3.3 \\
(5.1) \\
\{5.4\}\end{array}$ & $\begin{array}{l}.42 \\
(.71) \\
\{.84\}\end{array}$ & $\begin{array}{l}-.34 \\
(.53) \\
\{.55\}\end{array}$ & $\begin{array}{c}17 \\
(17) \\
\{18\}\end{array}$ & $\begin{array}{l}9.2 \\
(22) \\
\{21\}\end{array}$ & $\begin{array}{c}2.1 \\
(2) \\
\{2.1\}\end{array}$ & $\begin{array}{c}.94 \\
(2.2) \\
\{2.2\}\end{array}$ \\
\hline Treatment $\times H^{*}$ & $\begin{array}{l}-15 \\
(17) \\
\{17\}\end{array}$ & $\begin{array}{l}-.065 \\
(21) \\
\{20\}\end{array}$ & $\begin{array}{l}-1.7 \\
(1.9) \\
\{1.8\}\end{array}$ & $\begin{array}{l}.016 \\
(2.1) \\
\{1.9\}\end{array}$ & $\begin{array}{l}-17 \\
(24) \\
\{24\}\end{array}$ & $\begin{array}{l}9.5 \\
(28) \\
\{27\}\end{array}$ & $\begin{array}{c}-2 \\
(2.7) \\
\{2.7\}\end{array}$ & $\begin{array}{l}.85 \\
(2.8) \\
\{2.7\}\end{array}$ \\
\hline Control Mean & 99.2 & 99.2 & 99.2 & 99.2 & 130.6 & 130.6 & 130.6 & 130.6 \\
\hline Adjusted $R^{2}$ & .026 & .026 & .026 & .026 & .047 & .047 & .047 & .047 \\
\hline Observations & 12,422 & 12,394 & 12,422 & 12,394 & 6,983 & 6,965 & 6,983 & 6,965 \\
\hline
\end{tabular}

The unit of analysis is an adult. Outcomes are as in Columns 1 and 2 of Table 2 " $H^{*}$ " is the Herfindahl index of land ownership in the village, and each column represents a different measure of the index; for both the full sample and a restricted sample of those who own above 1 acre, both normalized and standardized separately for treatment and control areas. Estimation is as described in Section 2.3. Standard errors in parentheses are clustered by mandal; those in brackets are spatial as in Conley (2008). Significance based on the former is denoted: ${ }^{*} p<.10,{ }^{* *} p<.05,{ }^{* * *} p<.01$. 
Table A.12: Livestock values

\begin{tabular}{|c|c|c|c|c|}
\hline & Cattle & Buffaloes & All Others & Total \\
\hline & (1) & $(2)$ & (3) & (4) \\
\hline $\begin{array}{l}\text { Adjusted TE } \\
\left(\beta_{T}+0.36 * \beta_{N}\right)\end{array}$ & $\begin{array}{c}-3120 \\
(1888) \\
{[.11]}\end{array}$ & $\begin{array}{c}4089^{* * *} \\
(1380) \\
{[.008]}\end{array}$ & $\begin{array}{c}1264 \\
(1823) \\
{[.31]}\end{array}$ & $\begin{array}{c}2233 \\
(3119) \\
{[.28]}\end{array}$ \\
\hline $\begin{array}{l}\text { Main effect } \\
\left(\beta_{T}\right)\end{array}$ & $\begin{array}{c}-1567 \\
(1537) \\
{[.14]}\end{array}$ & $\begin{array}{c}1913^{*} \\
(1029) \\
{[.039]}\end{array}$ & $\begin{array}{c}-439 \\
(1445) \\
{[.38]}\end{array}$ & $\begin{array}{c}-94 \\
(2747) \\
{[.47]}\end{array}$ \\
\hline $\begin{array}{l}\text { Nbhd effect } \\
\left(0.36 * \beta_{N}\right)\end{array}$ & $\begin{array}{c}-1552 \\
(1043) \\
{[.17]}\end{array}$ & $\begin{array}{c}2176^{* *} \\
(878) \\
{[.024]}\end{array}$ & $\begin{array}{c}1704 \\
(1113) \\
{[.14]}\end{array}$ & $\begin{array}{c}2327 \\
(2105) \\
{[.18]}\end{array}$ \\
\hline Control mean & $14,024.1$ & $12,567.3$ & $15,754.2$ & $42,345.6$ \\
\hline Adjusted $R^{2}$ & .411 & .458 & .498 & .222 \\
\hline Observations & 157 & 157 & 157 & 157 \\
\hline
\end{tabular}

The unit of analysis is a mandal. The outcome in each column is the total value of livestock of the indicated type held per household, constructed using livestock counts and (district-level) prices from the 2012 Livestock Census. Estimation is as described in Section 2.3. Standard errors in parentheses are heteroskedasticity-robust; statistical significance based on these is denoted as: ${ }^{*} p<.10,{ }^{* *} p<.05,{ }^{* * *} p<.01$. $p$-values from randomization inference on 10,000 iterations are reported in square brackets 
Table A.13: Borrowing by lender and by purpose

\begin{tabular}{|c|c|c|c|c|c|c|c|c|c|}
\hline & \multirow{2}{*}{$\frac{\text { Total }}{(1)}$} & \multicolumn{3}{|c|}{ By lending type } & \multicolumn{5}{|c|}{ By purpose } \\
\hline & & $\begin{array}{c}(2) \\
\text { Formal }\end{array}$ & $\begin{array}{c}(3) \\
\text { Semi-Formal }\end{array}$ & $\begin{array}{c}(4) \\
\text { Informal }\end{array}$ & $\begin{array}{l}(5) \\
\text { Productive }\end{array}$ & $\begin{array}{c}(6) \\
\text { Smoothing } \\
\text { a shock }\end{array}$ & $\begin{array}{c}\text { (7) } \\
\text { Event }\end{array}$ & $\begin{array}{c}(8) \\
\text { Durables or } \\
\text { real estate }\end{array}$ & $\begin{array}{c}\text { (9) } \\
\text { Refinance }\end{array}$ \\
\hline $\begin{array}{l}\text { Adjusted TE } \\
\left(\beta_{T}+0.36 * \beta_{N}\right)\end{array}$ & $\begin{array}{c}20400^{* *} \\
(6403) \\
\{6356\}\end{array}$ & $\begin{array}{c}4207 \\
(2945) \\
\{2849\}\end{array}$ & $\begin{array}{c}1936 \\
(1695) \\
\{1672\}\end{array}$ & $\begin{array}{l}12560^{*} \\
(5598) \\
\{5769\}\end{array}$ & $\begin{array}{c}-895 \\
(2687) \\
\{2451\}\end{array}$ & $\begin{array}{l}11196^{*} \\
(5253) \\
\{5303\}\end{array}$ & $\begin{array}{l}4893^{*} \\
(2221) \\
\{2299\}\end{array}$ & $\begin{array}{c}541 \\
(547) \\
\{557\}\end{array}$ & $\begin{array}{c}1388 \\
(1719) \\
\{1855\}\end{array}$ \\
\hline $\begin{array}{l}\text { Main effect } \\
\left(\beta_{T}\right)\end{array}$ & $\begin{array}{l}11237^{*} \\
(4912) \\
\{4656\}\end{array}$ & $\begin{array}{c}2947 \\
(2339) \\
\{2200\}\end{array}$ & $\begin{array}{c}127 \\
(1024) \\
\{1013\}\end{array}$ & $\begin{array}{c}7188 \\
(4285) \\
\{4249\}\end{array}$ & $\begin{array}{c}413 \\
(2152) \\
\{1968\}\end{array}$ & $\begin{array}{c}5263 \\
(3853) \\
\{3734\}\end{array}$ & $\begin{array}{l}3876^{* *} \\
(1482) \\
\{1542\}\end{array}$ & $\begin{array}{l}1278^{*} \\
(505) \\
\{496\}\end{array}$ & $\begin{array}{c}945 \\
(1491) \\
\{1761\}\end{array}$ \\
\hline $\begin{array}{l}\text { Nbhd effect } \\
\left(0.36 * \beta_{N}\right)\end{array}$ & $\begin{array}{l}9163^{* *} \\
(3308) \\
\{3441\}\end{array}$ & $\begin{array}{c}1260 \\
(1734) \\
\{1735\}\end{array}$ & $\begin{array}{l}1808^{*} \\
(884) \\
\{865\}\end{array}$ & $\begin{array}{c}5372 \\
(2833) \\
\{2885\}\end{array}$ & $\begin{array}{l}-1308 \\
(1570) \\
\{1569\}\end{array}$ & $\begin{array}{l}5933^{*} \\
(2934) \\
\{3051\}\end{array}$ & $\begin{array}{c}1018 \\
(1331) \\
\{1350\}\end{array}$ & $\begin{array}{l}-738 \\
(387) \\
\{412\}\end{array}$ & $\begin{array}{c}443 \\
(903) \\
\{901\} \\
\end{array}$ \\
\hline $\begin{array}{l}\text { Baseline lag } \\
\text { Control mean } \\
\text { Adjusted } R^{2} \\
\text { Observations }\end{array}$ & $\begin{array}{c}\text { Yes } \\
66,403.6 \\
0.013 \\
4,840\end{array}$ & $\begin{array}{c}\text { Yes } \\
14,133.7 \\
0.017 \\
4,840\end{array}$ & $\begin{array}{c}\text { Yes } \\
4,749.5 \\
0.015 \\
4,839\end{array}$ & $\begin{array}{c}\text { Yes } \\
46,570.4 \\
0.013 \\
4,839\end{array}$ & $\begin{array}{c}\text { No } \\
11,337.1 \\
0.004 \\
4,892\end{array}$ & $\begin{array}{c}\text { No } \\
37,284.1 \\
0.012 \\
4,892\end{array}$ & $\begin{array}{c}\text { No } \\
6,735.8 \\
0.006 \\
4,892\end{array}$ & $\begin{array}{c}\text { No } \\
1,004.9 \\
0.024 \\
4,892\end{array}$ & $\begin{array}{c}\text { No } \\
9,602.1 \\
0.011 \\
4,892\end{array}$ \\
\hline
\end{tabular}

The unit of analysis is a household. "Productive" is defined as balance (in rupees) left of loans taken out to: i) start a new business; ii) acquire new assets; iii) to buy stock; iv) buy land; v) pay for education. "Smoothing a shock" is defined as balance (in rupees) left of loans taken out to: i) pay for a temporary difficulty; ii) pay for health expenses for household members or others; iii) expenses undergone during a period of unemployment. "Event" in column 7 is defined as balance (in rupees) left of loans taken out to pay for costs related to marriage, funeral, or other ceremonies. "Durables or real estate" in column 8 is defined as balance (in rupees) left of loans taken out to i) buy household durables; ii) pay for home improvements or repair; iii) pay for home construction. "Refinance" in column 9 is defined as balance (in rupees) left of loans taken out to repay old household or business debt. Estimation is as described in Section 2.3. Standard errors in parentheses are clustered by mandal; those in brackets are spatial as in Conley (2008). Significance based on the former is denoted: ${ }^{*} p<.10,{ }^{* *} p<.05,{ }^{* * *} p<.01$. 
Table A.14: Breakdown of effects on wage income

\begin{tabular}{lcc}
\hline & $\begin{array}{c}\text { Agricultural } \\
\text { labor income }\end{array}$ & $\begin{array}{c}\text { Non-agricultural } \\
\text { labor income }\end{array}$ \\
\cline { 2 - 3 } & $(1)$ & $(2)$ \\
\hline Adjusted TE & $3474^{* *}$ & $3786^{* *}$ \\
$\left(\beta_{T}+0.36 * \beta_{N}\right)$ & $(1647)$ & $(1667)$ \\
& $\{1735\}$ & $\{1833\}$ \\
Main effect & $3305^{* *}$ & $3255^{* *}$ \\
$\left(\beta_{T}\right)$ & $(1424)$ & $(1295)$ \\
Nbhd effect & $\{1429\}$ & $\{1351\}$ \\
$\left(0.36 * \beta_{N}\right)$ & 169 & 531 \\
& $(812)$ & $(848)$ \\
Control mean & $\{799\}$ & $\{911\}$ \\
Adjusted $R^{2}$ & $14,512.7$ & $9,133.3$ \\
Observations & .069 & .065 \\
\hline
\end{tabular}

The unit of analysis is a household. All outcomes are in Rs. per year. Outcomes are labor income from private-sector agricultural labor (Column 1) and from private-sector non-agricultural labor (Column 2). Estimation is as described in Section 2.3. Standard errors in parentheses are clustered by mandal; those in brackets are spatial as in Conley (2008). Significance based on the former is denoted: ${ }^{*} p<.10,{ }^{* *} p<.05,{ }^{* * *} p<.01$. 
Figure A.1: Study map

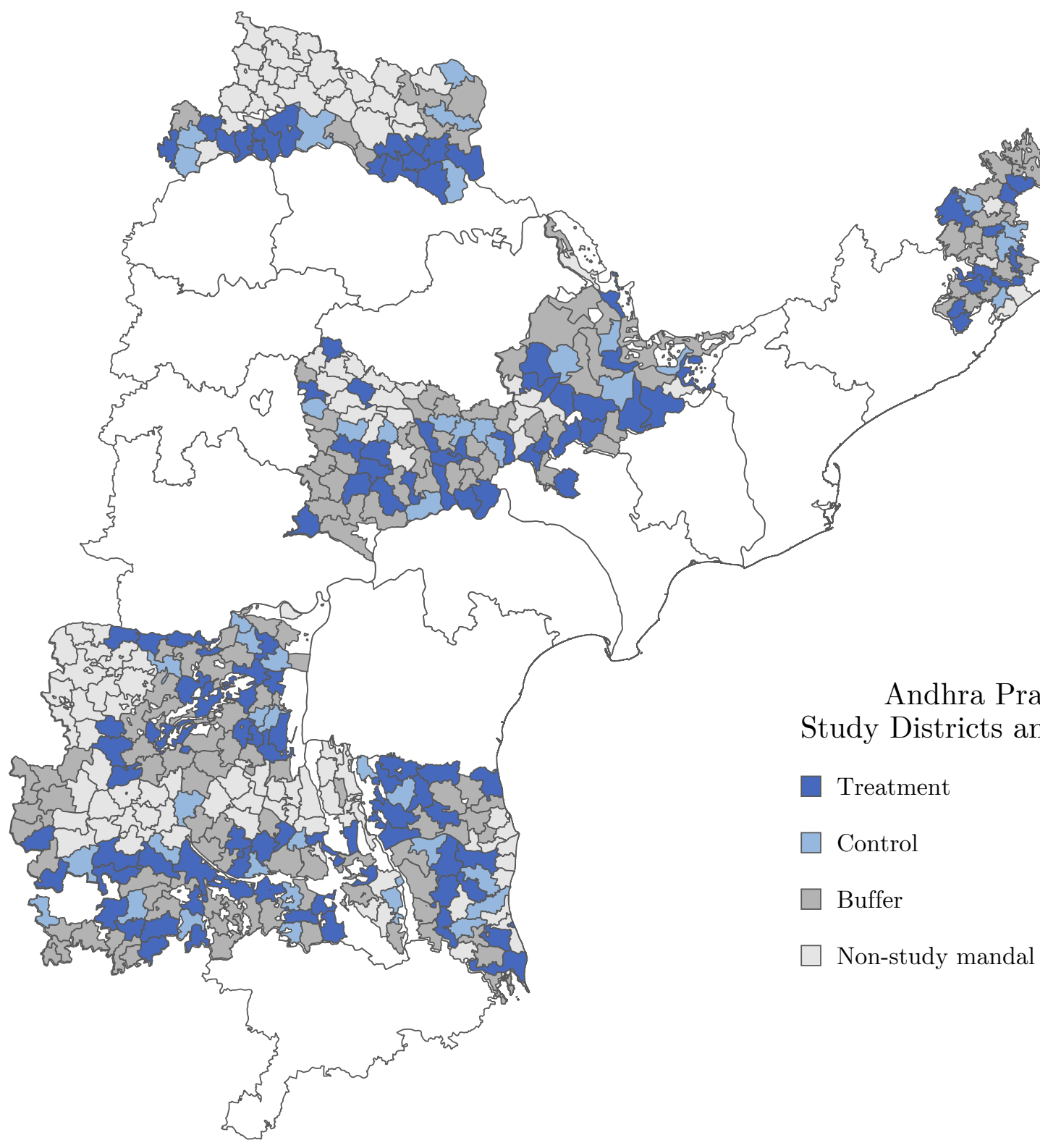

This map shows the 8 study districts - Adilabad, Anantapur, Kadapa, Khammam, Kurnool, Nalgonda, Nellore, and Vizianagaram - and the assignment of mandals (sub-districts) within those districts to study arms. Mandals were randomly assigned to one of three waves: 112 to wave 1 (treatment), 139 to wave 2, and 45 to wave 3 (control). Wave 2 was created as a buffer to maximize the time between program rollout in treatment and control waves; we did not collect survey data in these mandals. We did not assign "non-study" mandals to an arm because the Smartcards initiative had already started in those mandals or in some cases (109 out of 405) because they were entirely urban and thus had no NREGS activity. Randomization was stratified by district and by a principal component of mandal characteristics including population, literacy, proportion of Scheduled Caste and Tribe, NREGS jobcards, NREGS peak employment rate, proportion of SSP disability recipients, and proportion of other SSP pension recipients. The two mandals marked are examples of those which by had chance had a high (low) proportion of their neighbors treated. 
Figure A.2: Timing of data collection activities and reference periods

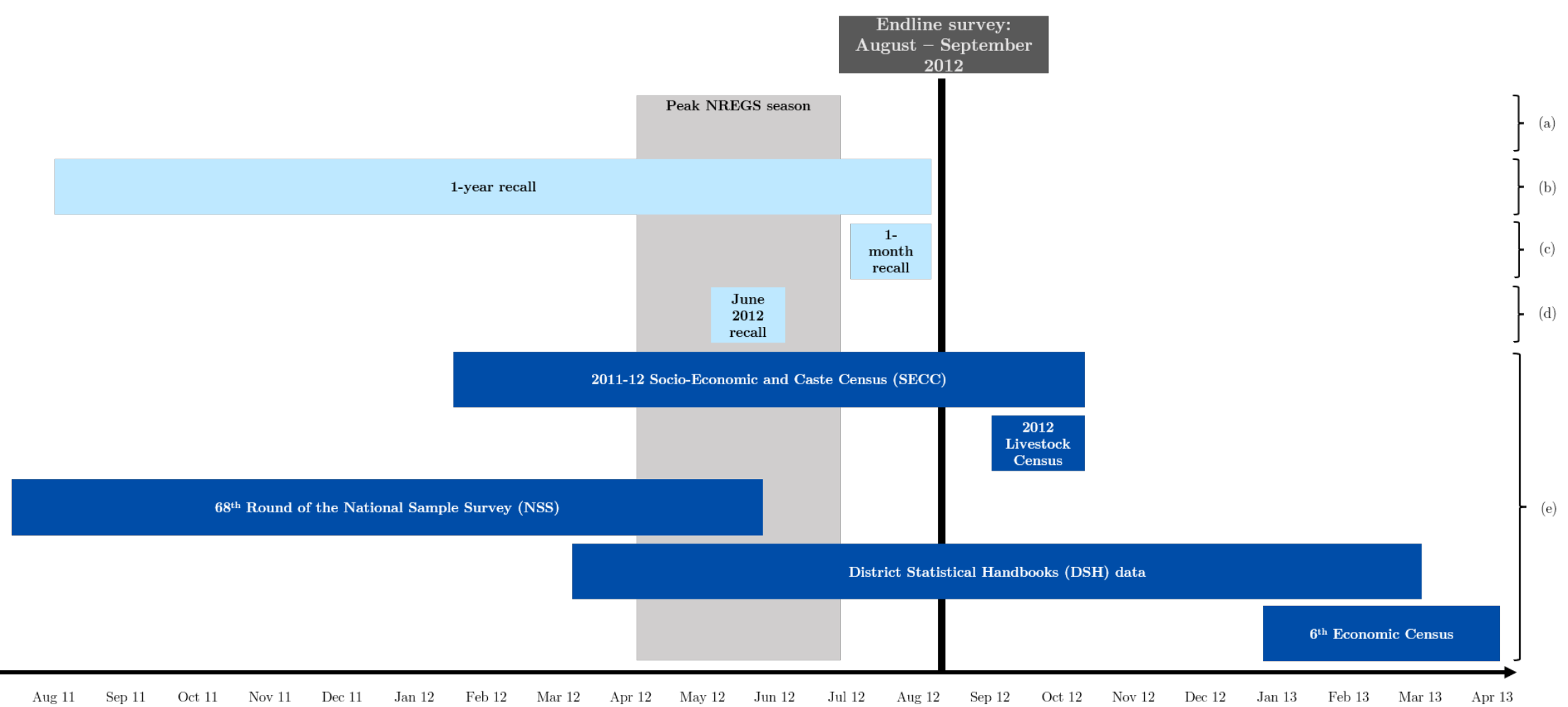

This figure illustrates the periods of time referenced by the various data sources we use. Rows labelled (b)-(d) show the recall periods used in our endline survey, which we conducted between August and September 2012. Those in dark blue are fixed with respect to the timing of the endline survey, while those in light blue are variable. These include (a) one-year recall for questions about household earnings/income and larger expenses, (b) one-month recall for questions on smaller expenses, (c) recall from June 2012 for key labor market outcomes (wages and employment), and (d) recall of the specific 7-week period from May 18 - July 14, 2012, which corresponds approximately to the typical season of peak activity on the NREGS, for questions about NREGS work and leakage and is the reference period used to calculate leakage in MNS. Rows labelled (e) show the coverage periods for independent data sources. Details on these are as follows: the 2011-2012 Socio-Economic and Caste Census was conducted in rural AP during 2012 and contains household-level data on earnings (in the month prior to the date of the interview) and land holdings (at time of the interview); the 2012 Livestock Census was conducted with October 15, 2012 as the reference date and contains data on mandal-level livestock headcounts as of that date; the 68th Round of the National Sample Survey was conducted in AP between July 2011 - June 2012 and contains data on household-level expenditure and number of units purchased for a variety of goods (in the month prior to the date of the interview); the District Statistical Handbooks, which the Andhra Pradesh Directorate of Economics publishes annually, contain data on land utilization and irrigation during April 2012 - March 2013; the 6th Economic Census, for which fieldwork was conducted in 2013 - 2014 and contains data on enterprises and employees. 


\section{Figure A.3: Income distribution by treatment status}

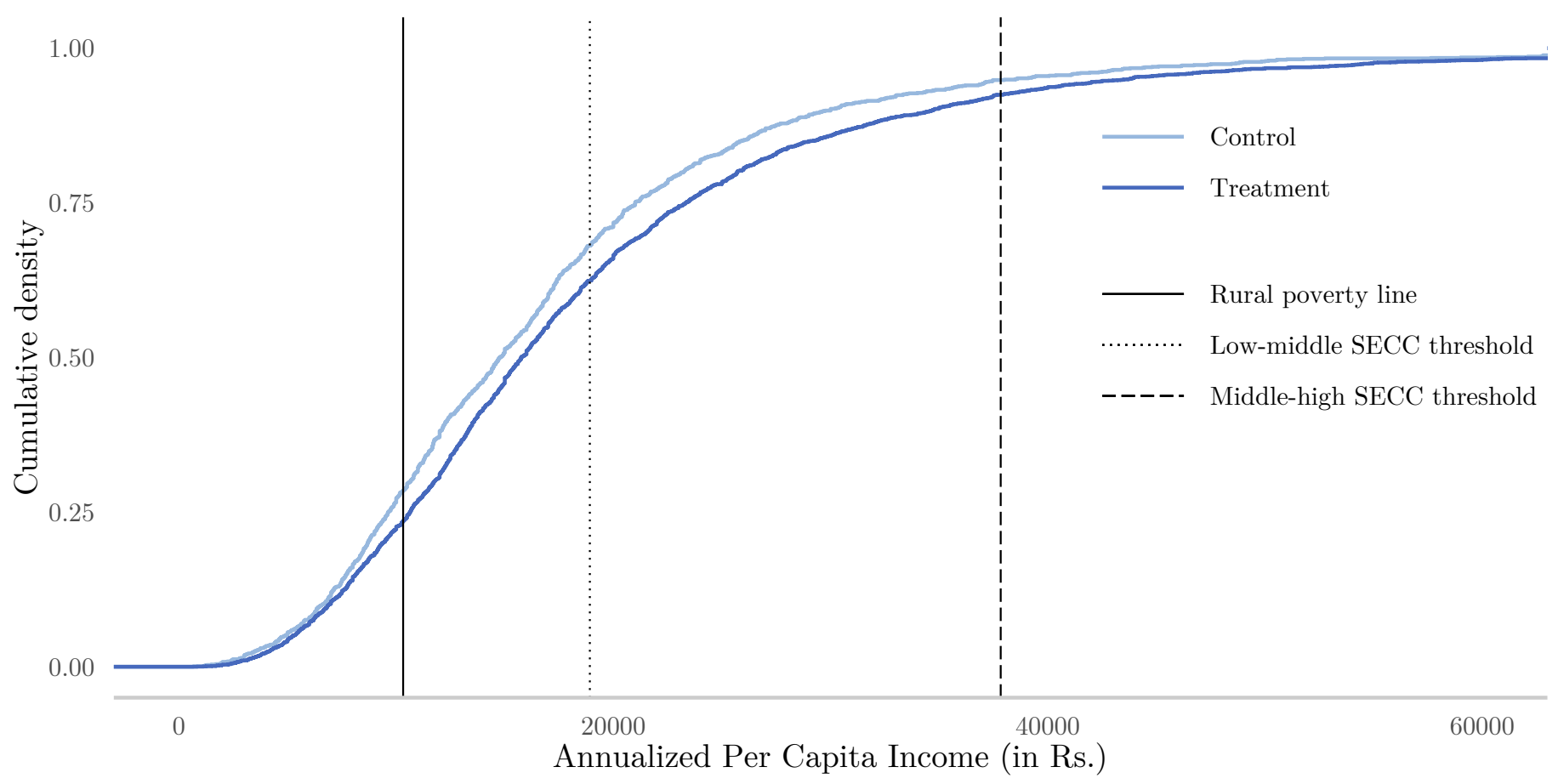

This figure plots the empirical cumulative distribution function of total annualized per capita income by household from the endline survey separately for households in the treatment (dark blue) and control (light blue) groups. The solid vertical line indicates the annualized official per capita poverty line (Rs. 860 per person per month or Rs. 10,320 per person per year). The dotted and dashed lines indicate the income category thresholds which, after adjustment using the estimated share of household earnings accruing the highest-earning member and the average household size, correspond to the income category thresholds reported in the SECC (of Rs. 5,000 and Rs. 10,000, respectively). 
Figure A.4: Logged income and land value
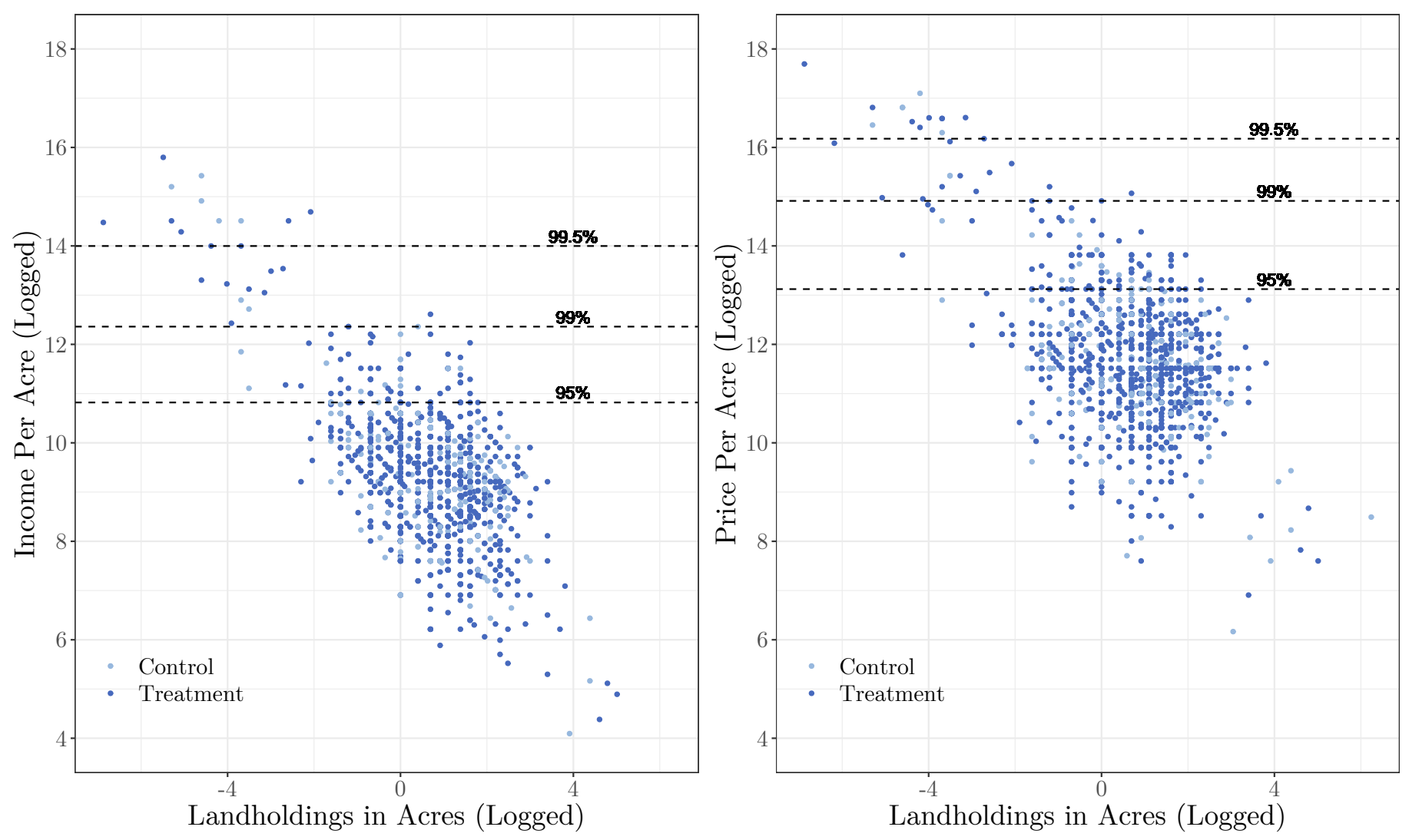

This figure plots the relationship between logged landholdings, logged income per acre, and logged price per acre (land value), as a supplement to our analysis in Table 3. Dashed lines indicate (from bottom to top) the 95th, 99th, and 99.5th percentiles of the distribution of logged income per acre. 
Figure A.5: Distribution of earnings per day by source

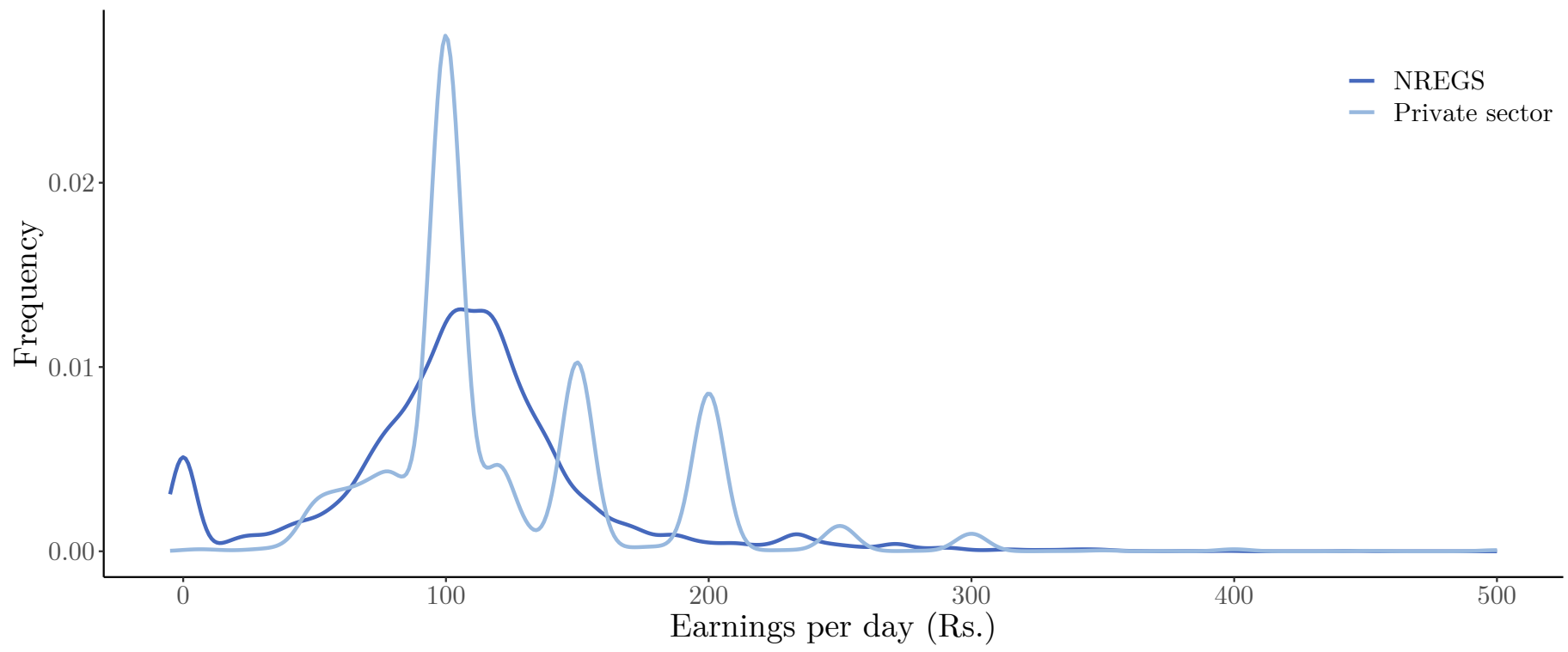

This figure plots the distribution of earnings per day for individuals who report positive days worked in June 2012 either on NREGS or in the private sector. NREGS earnings per day are calculated as the amount earned divided by days worked in June; private sector earnings per day are simply the daily wage the worker reported earning. 


\section{B Robustness checks}

In this section we examine robustness of our main results to various specification choices.

\section{B.1 Baseline lag}

As described previously, our survey data comprises of a repeated, representative cross-section of the sample of jobcard holders. Therefore, for individual and household-level outcomes, we do not have baseline observations for that particular individual or household. However, for potentially greater statistical power, and to possibly correct for any chance baseline imbalances, we include the baseline village-level outcome mean as a control variable in our main specifications. For aggregate outcomes, we do have corresponding baseline observations, and similarly include these as controls.

Below, we show robustness to excluding these baseline variables in specifications estimating the impact of our main outcome variables. Table B.2 shows that excluding the lag has very limited impact on our results, with a mild loss of statistical power in some cases (e.g. private sector employment), and a small increase in coefficient magnitudes in others (e.g. income).

\section{B.2 Truncation}

For certain outcomes such as income, we collected data at frequencies that were most natural for the respondent to report - weekly, monthly, or annual - and then multiplying appropriately to obtain the annualized number. In the case of land values, we similarly asked for the size unit and then the value. For these outcomes, data entry errors (in either the frequency, size, or amounts) could thus be exacerbated. To reduce the impact of outliers - resulting either from these data entry errors or otherwise - on our results, our main specifications truncate the top $0.5 \%$ of observations (separately in treatment and control) for certain outcomes. In Table B.1 we show robustness to including these observations. Again, there is no qualitative difference in our results; in most cases (income, wages) the coefficients are actually higher in magnitude, although in the case of land value the increased variance results in a mild loss in statistical power.

\section{B.3 Other robustness}

In examining heterogeneity of impacts by land concentration in villages, our main specification includes all land in the village while calculating the Herfindahl-Hirschman index. However, one might make the case that those with small amounts of land are not likely to employ external labor. Thus, in columns 2 and 4 of Table 6 and columns 2, 4, 6, and 8 of Table A.11 we show results excluding those with land below one acre in the calculation of the Herfindahl index; results are very similar.

In order to maintain a consistent sample for comparing employment outcomes, we use in our main specification the sample of workers who report their private-sector work, even when we are examining NREGS employment. We can expand our sample for NREGS employment outcomes if we include those for whom we have data on NREGS employment (either zero or positive reported days) but who did not report their private-sector work. Table B.3 shows that this yields very similar results. 
Table B.1: Robustness to not truncating outcomes

\begin{tabular}{|c|c|c|c|c|c|c|c|c|}
\hline & \multirow{2}{*}{$\begin{array}{c}\frac{\text { Annual income }}{(1)} \\
\text { Total }\end{array}$} & \multicolumn{2}{|c|}{ Wage } & \multicolumn{2}{|c|}{ Land } & & \multicolumn{2}{|c|}{ Assets and liabilities } \\
\hline & & $\begin{array}{c}(2) \\
\text { Reservation } \\
\text { wage }\end{array}$ & $\begin{array}{c}(3) \\
\text { Wage } \\
\text { realization }\end{array}$ & $\begin{array}{c}\text { (4) } \\
\text { Own-land } \\
\text { profits }\end{array}$ & $\begin{array}{c}(5) \\
\text { Value } \\
\text { per acre }\end{array}$ & $\begin{array}{c}(6) \\
\text { Annualized Expenditure } \\
\text { (Rs. per year) }\end{array}$ & $\begin{array}{c}(7) \\
\text { Total savings } \\
\quad(\text { Rs.) }\end{array}$ & $\begin{array}{c}(8) \\
\text { Total loans } \\
\quad(\text { Rs. })\end{array}$ \\
\hline $\begin{array}{l}\text { Adjusted TE } \\
\left(\beta_{T}+0.36 * \beta_{N}\right) \\
\text { Main effect } \\
\left(\beta_{T}\right) \\
\text { Nbhd effect } \\
\left(0.36 * \beta_{N}\right) \\
\end{array}$ & $\begin{array}{c}13151^{* *} \\
(5464) \\
10388^{* *} \\
(4454) \\
2762 \\
(3590) \\
\end{array}$ & $\begin{array}{c}7^{* *} \\
(3.4) \\
5.9^{*} \\
(3) \\
1.1 \\
(2.1) \\
\end{array}$ & $\begin{array}{c}13^{* * *} \\
(4.5) \\
7.9^{* *} \\
(4) \\
5.1^{*} \\
(2.8) \\
\end{array}$ & $\begin{array}{c}-.28^{* * *} \\
(.086) \\
-.13^{*} \\
(.077) \\
-.15^{* * *} \\
(.053) \\
\end{array}$ & $\begin{array}{c}.0067 \\
(.14) \\
-.0059 \\
(.11) \\
.013 \\
(.058) \\
\end{array}$ & $\begin{array}{c}759 \\
(5593) \\
313 \\
(4372) \\
446 \\
(3446) \\
\end{array}$ & $\begin{array}{c}1664^{*} \\
(918) \\
1243 \\
(866) \\
421 \\
(362)\end{array}$ & $\begin{array}{c}18321^{* * *} \\
(6712) \\
12584^{* *} \\
(4873) \\
5737 \\
(3908)\end{array}$ \\
\hline $\begin{array}{l}\text { Control mean } \\
\text { Adjusted } R^{2} \\
\text { Observations }\end{array}$ & $\begin{array}{l}71935 \\
.029 \\
4847\end{array}$ & $\begin{array}{c}99 \\
.03 \\
12726\end{array}$ & $\begin{array}{c}131 \\
.053 \\
7037\end{array}$ & $\begin{array}{c}10 \\
.072 \\
2573\end{array}$ & $\begin{array}{c}12 \\
.16 \\
3068\end{array}$ & $\begin{array}{c}85031 \\
.013 \\
4892\end{array}$ & $\begin{array}{r}2966 \\
.004 \\
4832\end{array}$ & $\begin{array}{l}68108 \\
.011 \\
4858\end{array}$ \\
\hline
\end{tabular}

Refer to Tables 1, 2, 3 and 7 for our main specification and variable descriptions. Standard errors are clustered at the mandal level in parentheses, and statistical significance based on these is denoted as: ${ }^{*} p<.10,{ }^{* *} p<.05,{ }^{* * *} p<.01$. 
Table B.2: Robustness to excluding baseline lag

\begin{tabular}{|c|c|c|c|}
\hline & $\begin{array}{c}\text { Adjusted TE } \\
\left(\beta_{T}+0.36 * \beta_{N}\right) \\
\end{array}$ & $\begin{array}{c}\text { Main effect } \\
\left(\beta_{T}\right) \\
\end{array}$ & $\begin{array}{l}\text { Nbhd effect } \\
\left(0.36 * \beta_{N}\right)\end{array}$ \\
\hline & $(1)$ & $(2)$ & \\
\hline Total income & $\begin{array}{l}10634^{*} \\
(4494)\end{array}$ & $\begin{array}{l}9804^{* *} \\
(3676)\end{array}$ & $\begin{array}{c}830 \\
(2641)\end{array}$ \\
\hline Reservation wage & $\begin{array}{l}6.4^{*} \\
(3.2)\end{array}$ & $\begin{array}{c}5.3 \\
(2.8)\end{array}$ & $\begin{array}{c}1.2 \\
(1.8)\end{array}$ \\
\hline Wage realization & $\begin{array}{l}12^{* *} \\
(4.4)\end{array}$ & $\begin{array}{l}7.6^{*} \\
(3.6)\end{array}$ & $\begin{array}{c}4.7 \\
(2.5)\end{array}$ \\
\hline Days self-employed or not working & $\begin{array}{c}-2.5^{* *} \\
(.76)\end{array}$ & $\begin{array}{c}-1.5^{* *} \\
(.58)\end{array}$ & $\begin{array}{l}-.99^{*} \\
(.41)\end{array}$ \\
\hline Days worked in NREGS & $\begin{array}{l}1.1^{*} \\
(.44)\end{array}$ & $\begin{array}{l}.7 \\
(.39)\end{array}$ & $\begin{array}{l}.37 \\
(.2)\end{array}$ \\
\hline Days worked in private sector & $\begin{array}{c}1.3 \\
(.81)\end{array}$ & $\begin{array}{c}.63 \\
(.58)\end{array}$ & $\begin{array}{l}.68 \\
(.4)\end{array}$ \\
\hline Total savings (Rs.) & $\begin{array}{c}182 \\
(322)\end{array}$ & $\begin{array}{c}-17 \\
(279)\end{array}$ & $\begin{array}{c}198 \\
(157)\end{array}$ \\
\hline Total loans (Rs.) & $\begin{array}{c}21423^{* * *} \\
(6175)\end{array}$ & $\begin{array}{l}11915^{*} \\
(4809)\end{array}$ & $\begin{array}{l}9508^{* *} \\
(3258)\end{array}$ \\
\hline Owns land $(\%)$ & $\begin{array}{l}.075^{*} \\
(.034)\end{array}$ & $\begin{array}{l}.063^{*} \\
(.025)\end{array}$ & $\begin{array}{c}.012 \\
(.019)\end{array}$ \\
\hline Annualized Expenditure (Rs. per year) & $\begin{array}{c}2045 \\
(4760)\end{array}$ & $\begin{array}{c}82 \\
(3990)\end{array}$ & $\begin{array}{c}1963 \\
(2637)\end{array}$ \\
\hline Did migrate, & $\begin{array}{l}.041 \\
(.022)\end{array}$ & $\begin{array}{l}.027 \\
(.018)\end{array}$ & $\begin{array}{l}.013 \\
(.01)\end{array}$ \\
\hline Days migrated & $\begin{array}{c}3.7 \\
(6.6)\end{array}$ & $\begin{array}{c}1.7 \\
(5.2)\end{array}$ & $\begin{array}{c}2 \\
(2.4)\end{array}$ \\
\hline Household size & $\begin{array}{l}.071 \\
(.13)\end{array}$ & $\begin{array}{l}.059 \\
(.1)\end{array}$ & $\begin{array}{l}.012 \\
(.08)\end{array}$ \\
\hline Migration common in May, & $\begin{array}{l}.027 \\
(.074)\end{array}$ & $\begin{array}{l}.044 \\
(.056)\end{array}$ & $\begin{array}{l}-.017 \\
(.035)\end{array}$ \\
\hline
\end{tabular}

Refer to Tables 1, 2, 7, and A.5 for our main specification and variable descriptions. Standard errors are clustered at the mandal level in parentheses, and statistical significance based on these is denoted as: ${ }^{*} p<.10,{ }^{* *} p<.05,{ }^{* * *} p<.01$. 
Table B.3: Robustness to including full NREGS sample

\begin{tabular}{lc}
\hline & $\begin{array}{c}\text { Days worked } \\
\text { in NREGS }\end{array}$ \\
\cline { 2 - 2 } & $(1)$ \\
\hline Adjusted TE & $.92^{* *}$ \\
$\left(\beta_{T}+0.36 * \beta_{N}\right)$ & $(.42)$ \\
Main effect & $.61^{*}$ \\
$\left(\beta_{T}\right)$ & $(.37)$ \\
Nbhd effect & .31 \\
$\left(0.36 * \beta_{N}\right)$ & $(.2)$ \\
\hline Control Mean & 3.6 \\
Adjusted $R^{2}$ & .040 \\
Observations & 17,974 \\
\hline
\end{tabular}

Refer to Table 2 for our main specification and variable descriptions. Standard errors are clustered at the mandal level in parentheses, and statistical significance based on these is denoted as: ${ }^{*} p<.10,{ }^{* *} p<.05,{ }^{* * *} p<.01$. 


\section{Data description and recall quality}

This appendix describes the construction of the various outcomes we report in more detail, and addresses potential issues related to recall.

\section{C.1 External data sources}

Of the five government data sources described in the text, three are censuses, and hence there is no more to add in terms of sampling strategies or sample covered. One of the other two, the National Sample Survey, is well-documented (see below) and the basis for numerous papers written on India. The last, the District Statistical Handbook, provides very little documentation (but we use it only for supplemental Appendix tables). Table C.4 records the description and temporal scope of variables from these sources used in our analysis, and further documentation on each is available as follows:

- Socio-Economic and Caste Census (SECC): Collected by the Government of India, Ministry of Rural Development, the SECC has its own dedicated website at https://secc.gov.in/welcome.

- Livestock Census: Collected by the Government of India, Department of Animal Husbandry, further information is available at http://dahd.nic.in/about-us/divisions/statistics.

- Economic Census: Collected by the Government of India, Ministry of Statistics and Programme Implementation, further details are available at http://mospi.nic.in/economic-census-3.

- National Sample Survey (NSS): Collected by the Government of India, National Sample Survey Organization, further information is available at http://mospi.nic.in/NSSOa.

- District Statistical Handbooks: Collected by the Government of Andhra Pradesh and based on data from the Office of the Surveyor General of India, further information can be obtained at http://eands.dacnet.nic.in/.

\section{C.2 Survey data and outcomes}

We conducted two rounds of household surveys, a baseline survey in August-September 2010 and an endline survey in August-September 2012. At endline, we sampled 5,278 households, completing surveys with 4,943 (94\%), identifying 200 as ghost households, and being unable to survey or confirm the existence of 135. The corresponding baseline numbers were 5,244, 4,646, 68 and 530 respectively. Note that these totals differ from those we report in MNS as the latter also include a separate sample of pension beneficiaries. We also surveyed one knowledgeable local leader (a village elder, schoolteacher, or local official); from this survey we use solely a question on prevailing private sector daily wages by month of the year.

The household survey was comprised of seven modules. Module A was the household roster, collecting demographic data on individual members and household characteristics. Module B asked about enrollment and experiences with Smartcards. Module C asked about payments and involvement with the welfare programs, with separate modules for SSP and NREGS samples. Module D asked about consumption, Module E about income, Module F about assets and Module G about other household balance sheet items. We administered all modules except $\mathrm{B}$ and $\mathrm{C}$ to either the male or female head of household, with supplemental responses on consumption obtained from the most knowledgeable person as necessary. We administered modules B and C, which asked about beneficiary experience with Smartcards and the welfare programs, to the individual beneficiaries themselves, collecting separate responses 
for each individual beneficiary within the household. Table C.4 describes each of the outcomes used in the main tables, along with a handful of other important variables used in the analysis.

\section{C.3 Recall issues}

Given the lag between survey data collection and actual work done and payments received-typically 2 months, a maximum of 4 months - it is possible that recall issues affect our analysis. Our particular concern is with differential recall by treatment status, which might bias estimated treatment effects. We designed data collection intentionally to address this issue, drawing on lessons learned measuring the same outcomes in our own previous work in the area (Niehaus and Sukhtankar, 2013a.b) and using standard best-practices. For example, we jogged respondents memory of their NREGS employment by referring to the recording of work in the physical jobcard (which would not have been affected by treatment, which varied neither the format nor the recording of jobcard entries). To further test for and rule out differential recall ex post for our various key outcomes, we use the following approaches:

- NREGS employment and earnings. If treatment made NREGS employment or payments being more salient, it is possible that treated respondents remember these quantities better. The employment results reported in our survey, however, are in line with those from independent audits which we conducted ourselves to count attendence at NREGS worksites, suggesting that the increase in NREGS employment is not driven by differential recall (see MNS Appendix B.3 and E.2 for details). We can also use the fact that our survey was spread over two months to check directly whether there was indeed differential recall. Table C.3 shows that there is no systematic or significant relationship between survey week and treatment impact, suggesting that differential recall does not drive our results.

- Private sector employment. It is less clear why a reform to the NREGS would affect recall of privatesector labor market outcomes. One possibility, however, is that respondents confuse NREGS employment with private sector employment, so that a treatment-induced increase in the former generates a bias associated with treatment in the latter. A priori we view this sort of confusion as unlikely, as the NREGS was a very salient and distinctive scheme run by different people and involving different kinds of work than private enterprise. We can also examine directly whether respondents double-count days of NREGS and private sector employment (in which case they would report a total of more than 30 days of activity in the past 30 days) and whether treatment affected this. We see that the control group mean is exactly 30 days, indicating no double-counting, and that the treatment effect is if anything slightly negative, the opposite of what we would expect if treatment induced double-counting C.1. We also find significant positive spillover effects on days worked (Table 2) which cannot be explained by treatment effects on recall, since they are identified conditional on the respondents' own treatment status. Finally, if we test directly for differential recall using differences in survey timing we again see no systematic relationship (Table C.3).

- Private sector daily wages. As with private-sector employment it is not obvious how a reform to NREGS would affect recall of private-sector wages. One possibility is that people confuse their earnings from the two sources, reporting higher wages when in fact it was NREGS earnings that increased. We view this sort of confusion as unlikely given the different pay structures used in the two types of work (NREGS earnings are in piece rates while private sector earnings are in daily wages), different cash-out points (correspondent banking agents v.s. private employers), and the fact that these outcomes were measured in non-continguous parts of the survey (private sector wages at the beginning, NREGS earnings later). In any case, we see no treatment effect on NREGS 
earning per day (Table C.2), as NREGS earnings gains were driven by increases in days worked, so confusion with this outcome cannot explain reports of higher private sector wages. We also see significant spillover effects on market wages (Table2), which cannot be explained by own treatment status, and treatment effects on reservation wages which were not payments actually received.

Table C.1: Total days reported

\begin{tabular}{lcc}
\hline Adjusted TE & $-.32^{*}$ & $-.34^{*}$ \\
$\left(\beta_{T}+0.36 * \beta_{N}\right)$ & $(.19)$ & $(.19)$ \\
& $\{.22\}$ & $\{.22\}$ \\
Main effect & -.29 & -.3 \\
$\left(\beta_{T}\right)$ & $(.18)$ & $(.18)$ \\
& $\{.2\}$ & $\{.2\}$ \\
Nbhd effect & -.033 & -.035 \\
$\left(0.36 * \beta_{N}\right)$ & $(.079)$ & $(.082)$ \\
& $\{.08\}$ & $\{.084\}$ \\
\hline Baseline lag & Yes & No \\
Control mean & 30.1 & 30.1 \\
Adjusted $R^{2}$ & .017 & .015 \\
Observations & 13,713 & 13,798 \\
\hline
\end{tabular}

The unit of analysis is an adult. The outcome variable is the total days reported doing various activities. This was not required to add up to 30 days. Column 1 includes a baseline lag, Column 2 does not. Estimation is as described in Section 2.3. Standard errors in parentheses are clustered by mandal; those in brackets are spatial as in Conley (2008). Significance based on the former is denoted: ${ }^{*} p<.10,{ }^{* *} p<.05,{ }^{* * *} p<.01$. 
Table C.2: NREGS earnings per day

\begin{tabular}{lcc}
\hline Adjusted TE & -.78 & -1.1 \\
$\left(\beta_{T}+0.36 * \beta_{N}\right)$ & $(5.1)$ & $(5.1)$ \\
& $\{5.4\}$ & $\{5\}$ \\
Main effect & -2.8 & -3 \\
$\left(\beta_{T}\right)$ & $(5.1)$ & $(5)$ \\
& $\{5.5\}$ & $\{5.1\}$ \\
Nbhd effect & 2 & 1.9 \\
$\left(0.36 * \beta_{N}\right)$ & $(3.5)$ & $(3.5)$ \\
& $\{3.6\}$ & $\{3.6\}$ \\
\hline Baseline lag & Yes & No \\
Control mean & 116 & 116 \\
Adjusted $R^{2}$ & .03 & .03 \\
Observations & 6392 & 6426 \\
\hline
\end{tabular}

The unit of analysis is an adult. The outcome variable is NREGS earnings per day of work. This was calculated by dividing reported NREGS earnings in June 2012 by reported days spent working in NREGS in the same period. Column 1 includes a baseline lag, Column 2 does not. Estimation is as described in Section 2.3. Standard errors in parentheses are clustered by mandal; those in brackets are spatial as in Conley (2008). Significance based on the former is denoted: ${ }^{*} p<.10,{ }^{* *} p<.05,{ }^{* * *} p<.01$.

Table C.3: Differential effects by recall length

\begin{tabular}{|c|c|c|c|c|}
\hline & \multicolumn{3}{|c|}{ Employment } & \multirow{2}{*}{$\begin{array}{c}\text { Wages } \\
(4) \\
\text { NREGS earnings in June }\end{array}$} \\
\hline & $\begin{array}{l}(1) \\
\text { Days self-employed } \\
\text { or not working }\end{array}$ & $\begin{array}{c}(2) \\
\text { Days worked } \\
\text { in NREGS }\end{array}$ & $\begin{array}{c}(3) \\
\text { Days worked } \\
\text { in private sector }\end{array}$ & \\
\hline Treatment & $\begin{array}{c}-1.1 \\
(1.4)\end{array}$ & $\begin{array}{l}.47 \\
(.7)\end{array}$ & $\begin{array}{l}-.11 \\
(1.2)\end{array}$ & $\begin{array}{c}134 \\
(121)\end{array}$ \\
\hline Survey Week & $\begin{array}{l}.061 \\
(.24)\end{array}$ & $\begin{array}{l}-.16 \\
(.11)\end{array}$ & $\begin{array}{c}-.012 \\
(.21)\end{array}$ & $\begin{array}{c}11 \\
(20)\end{array}$ \\
\hline Treatment $\times$ Survey Week & $\begin{array}{l}-.041 \\
(.28)\end{array}$ & $\begin{array}{l}.025 \\
(.13)\end{array}$ & $\begin{array}{l}.14 \\
(.25)\end{array}$ & $\begin{array}{l}-5.4 \\
(23)\end{array}$ \\
\hline $\begin{array}{l}\text { Control mean } \\
\text { Adjusted } R^{2} \\
\text { Observations }\end{array}$ & $\begin{array}{c}17 \\
.067 \\
13713\end{array}$ & $\begin{array}{c}3.5 \\
.04 \\
13713\end{array}$ & $\begin{array}{c}7.9 \\
.018 \\
13713\end{array}$ & $\begin{array}{c}704 \\
.1 \\
13713\end{array}$ \\
\hline
\end{tabular}

The unit of analysis is an adult. The outcomes are wage and employment outcomes. Survey week is coded as 0 for the first week and +1 for each week after that, i.e 1 for the second, 3 for the fourth etc. Estimation is as described in Section 2.3. Standard errors in parentheses are clustered by mandal. Significance is denoted: ${ }^{*} p<.10,{ }^{* *} p<.05,{ }^{* * *} p<.01$. 
Table C.4: Key outcomes and sources

\begin{tabular}{|c|c|c|c|c|}
\hline $\begin{array}{l}\text { Table } \\
\#\end{array}$ & Variable & Description & Timing & Source \\
\hline 1 & Total income & $\begin{array}{l}\text { Total household income, summed over } 13 \text { separate } \\
\text { categories, and annualized }\end{array}$ & Last 12 months & $\begin{array}{l}\text { Household survey, module E, } \\
\text { household head }\end{array}$ \\
\hline 1 & NREGA income & $\begin{array}{l}\text { Earnings from employment in NREGS from all } \\
\text { household members }\end{array}$ & Last 12 months & $\begin{array}{l}\text { Household survey, module E, } \\
\text { household head }\end{array}$ \\
\hline 1 & Wage labor & $\begin{array}{l}\text { The sum of earnings from agricultural labor and } \\
\text { other physical labor, both done for someone else } \\
\text { and specifically non-NREGS }\end{array}$ & Last 12 months & $\begin{array}{l}\text { Household survey, module E, } \\
\text { household head }\end{array}$ \\
\hline 1 & Self-employment & $\begin{array}{l}\text { The sum of earnings from own farm, livestock, and } \\
\text { other businesses }\end{array}$ & Last 12 months & $\begin{array}{l}\text { Household survey, module E, } \\
\text { household head }\end{array}$ \\
\hline 1 & Misc income & $\begin{array}{l}\text { The sum of earnings from all other categories: } \\
\text { pensions, government and other salaried posi- } \\
\text { tions, gifts, and miscellaneous }\end{array}$ & Last 12 months & $\begin{array}{l}\text { Household survey, module E, } \\
\text { household head }\end{array}$ \\
\hline 2 & Reservation wage & $\begin{array}{l}\text { Obtained by asking whether worker would be wil- } \\
\text { ing to work for a given daily wage, starting with } \\
\text { Rs. } 20 \text { and moving up in Rs. } 5 \text { increments until } \\
\text { first "yes" response }\end{array}$ & Month of June & $\begin{array}{l}\text { Household survey, module A, } \\
\text { household head/ind worker }\end{array}$ \\
\hline 2 & Wage realization & $\begin{array}{l}\text { Average daily wage received on labor for someone } \\
\text { else }\end{array}$ & Month of June & $\begin{array}{l}\text { Household survey, module A, } \\
\text { household head/ind worker }\end{array}$ \\
\hline 2 & $\begin{array}{l}\text { Days self-employed } \\
\text { or not working }\end{array}$ & $\begin{array}{l}\text { The sum of days where one was not paid by some- } \\
\text { one else, and days spent not working }\end{array}$ & Month of June & $\begin{array}{l}\text { Household survey, module A, } \\
\text { household head/ind worker }\end{array}$ \\
\hline 2 & Days worked NREGS & $\begin{array}{l}\text { The number of days spent working on NREGS, } \\
\text { captured weekly and aggregated to month of June }\end{array}$ & $\begin{array}{l}\text { Study period } \\
\text { spanning June }\end{array}$ & $\begin{array}{l}\text { Household survey, module } \mathrm{C} \text {, } \\
\text { ind beneficiary }\end{array}$ \\
\hline 2 & $\begin{array}{l}\text { Days worked private } \\
\text { sector }\end{array}$ & $\begin{array}{l}\text { The number of days spent doing labor for someone } \\
\text { else for pay }\end{array}$ & Month of June & $\begin{array}{l}\text { Household survey, module A, } \\
\text { household head/ind worker }\end{array}$ \\
\hline
\end{tabular}



in every village, using median village unit values from control group

periods; 1 week

Log unit values of individual commodities using all available data

to 1 year

NSS reference

NSS Round 68, 2012

periods; 1 week

to 1 year

$5 \quad$ \# enterprises

The response to question "if you were to sell your land (today) how much would you get for it" divided by number of acres of land owned

Monthly income of highest earning household member, by category

As of time surveyed

Last 12 months

As of time surveyed

All units engaged in production or distribution of goods and services other than for purposes of own consumption, other than establishments engaged in crop production, public administration, defence, and illegal activities

All persons (including children under 15 years of age) working in an establishments either as owners, members of the household working as coowner or partner or helping the owner in running the establishment, whether hired or not, besides regular and salaried employees, casual/ daily wage labourers would be considered as workers for that establishment

Includes rearing of livestock, any support services for the same, and hunting/trapping and related activities

\section{As of time sur- Economic Census 2013} veyed

As of time sur- Economic Census 2013 veyed

As of time sur- Economic Census 2013 veyed

Household survey, module E, household head

Household survey, module E, household head

SECC 2012 
Firms in Manufac- Includes all manufacturing of all goods, repair, turing/Construction

Firms in sale/Retail and installation of machinery; as well as firms involved in construction
Firms in other sectors

Herfindahl index

Annualized expenditure

Total savings

$7 \quad$ Total loans

$7 \quad$ Owns land
Includes forestry and logging, fishing, power and water supply, mining,

Herfindahl index based on all landholdings in the village

The household's estimated annual expenditure in Rupees

The sum of savings in bank accounts, self-help group accounts, and cash

The total amount of outstanding loans from all sources
Whether the household owns land
As of time surveyed

As of time sur- Economic Census 2013 veyed

Economic Census 2013

As of time sur-

Economic Census 2013 veyed

As of time sur- SECC 2012

veyed

As of time surveyed

As of time surveyed

As of time sur-

veyed

As of time sur- Household survey, module E, veyed
Household survey, module E, household head

Household survey, module E, household head

Household survey, module G, household head household head

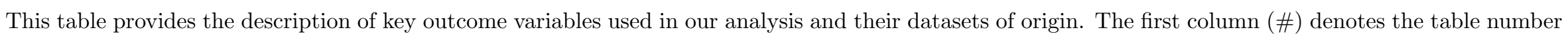

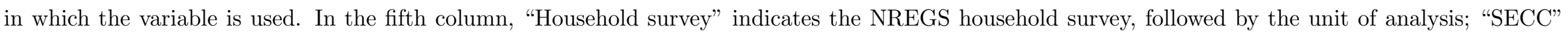
indicates the Socio-economic and Caste Census (2011); and "NSS" indicates the National Sample Survey and its corresponding round and year. 


\section{Sampling frame composition}

The database of NREGS-registered households from which we draw our sample changes over time as new households apply for the program and old ones are removed, as for example due to death, migration, or changes to family structure. This appendix examines whether treatment affected the composition of this group, and thus whether the treatment effects we see on endline outcomes might in part reflect compositional changes.

In Table D.2 we examine effects on overall rates of exit, entry, and net change in the jobcard database. In the control group (Column 2), new entrants into the database represented $6.3 \%$ of the jobcards present at baseline, while $2.6 \%$ of baseline jobcards dropped out, for a net change of $3.6 \%$. These numbers are small, reflecting the fact that most potential NREGS participants would likely have obtained a job card by the time Smartcards rolled out. In the treatment group (Column 1) the corresponding figures are quite similar. When we calculate regression-adjusted differences between the two using the same controls (district fixed effects and the first principal component of a vector of mandal characteristics) that we use in our main estimating equations, we see small estimated differences (Column 3) none of which are significantly different from zero (Column 4). Overall we can reject large treatment effects on the levels of entry, exit, and net change.

In Table D.3 we examine whether treatment is associated with differential changes in the composition of our sampling frame along a set of time-invariant characteristics. The sample for this exercise pools together all households surveyed at either baseline or endline, and is thus roughly twice as large as our main estimation sample. We find that treatment is not significantly associated with any characteristics

at baseline (Row 1) and that it is not differentially associated with any characteristics at endline relative to baseline (Row 3), with consistently small estimated relationships. This shows that treatment was not associated with large or significant changes in the kinds of households registered to participate in NREGS.

Finally, in Table D.4 we conduct a similar exercise focusing on the characteristics of endline entrants into our sample relative to non-entrants, examining whether this is different in treated as opposed to control areas. By focusing on entrants specifically this approach may give us more power to detect compositional effects than the test on overall composition in Table D.3. Reassuringly, however, we find that we still cannot reject the null of no treatment-control difference in the relationship between entrant status and characteristics, for any characteristic. 
Table D.1: Non-response and response composition rates by treatment status

\begin{tabular}{|c|c|c|c|c|c|}
\hline & $\frac{\text { Treatment }}{(1)}$ & $\frac{\text { Control }}{(2)}$ & $\frac{\text { Difference }}{(3)}$ & $\frac{p \text {-value }}{(4)}$ & $\frac{N}{(5)}$ \\
\hline Wage realization (Rs.) & .013 & .011 & .0018 & .59 & 7370 \\
\hline Reservation wage (Rs.) & .4 & .39 & .0073 & .64 & 21437 \\
\hline Days worked private sector & .33 & .3 & .031 & .037 & 21437 \\
\hline Days self-employed or not working & .34 & .33 & .019 & .13 & 21437 \\
\hline Days worked on NREGS & .15 & .13 & .027 & .02 & 21437 \\
\hline Days worked private sector $>0$ & .52 & .49 & .028 & .2 & 14514 \\
\hline Wage realization $\geq$ reservation wage & .98 & .99 & -.0029 & .57 & 7287 \\
\hline
\end{tabular}

This table compares (non-)response rates to questions regarding labor market outcomes across treatment arms. Columns 1-2 report the proportion of missing answers to the respective question in treatment and control. Column 3 reports the regression-adjusted treatment difference between treatment and control from a linear regression which also includes district fixed effects and the first principal component of a vector of mandal characteristics used to stratify randomization as control variables. Column 4 reports the p-value of a test that the parameter estimated in Column 3 is zero. Column 5 reports the number of individuals from whom answers were sought, which was the full sample except as noted below. Outcomes in each row are described in Table 2. Responses were sought from less than the full sample in the following cases: for "Wage realization (Rs.)" we asked the set of individuals who reported a strictly positive number of days worked for someone else; for "Wage realization $\geq$ Reservation wage" is the set of individuals that had non-missing values for both average daily wages and reservation wage. Standard errors clustered at the mandal level are in parentheses. Statistical significance is denoted as: ${ }^{*} p<.10,{ }^{* *} p<.05,{ }^{* * *} p<.01$.

Table D.2: Attrition from and entry into sample frames by treatment status

\begin{tabular}{|c|c|c|c|c|}
\hline & Treatment & Control & $\begin{array}{c}\text { Regression- } \\
\text { adjusted } \\
\text { difference }\end{array}$ & $p$-value \\
\hline & $(1)$ & $(2)$ & $(3)$ & $(4)$ \\
\hline Attriters from Baseline & .014 & .026 & -.013 & 0.19 \\
\hline Entrants in Endline & .064 & .063 & .0013 & 0.82 \\
\hline Net $\%$ change in jobcards & .05 & .036 & .0083 & 0.45 \\
\hline Net $\%$ change in jobcards (sampled GPs) & .044 & .031 & .015 & 0.31 \\
\hline
\end{tabular}

These tables compare the entire NREGS sample frame - i.e., all jobcard holders - across treatment (column 1) and control (column 2) mandals. Column 3 reports the difference in treatment and control means, while column 4 reports the p-value on the treatment indicator, both from simple regressions of the outcome with district fixed effects and the first principal component of a vector of mandal characteristics used to stratify randomization as the only controls. Row 1 presents the proportion of NREGS jobcards and SSP beneficiaries that dropped out of the sample frame between baseline and endline. Row 2 presents the proportion that entered the sample frame between baseline and endline. Row 3 presents the net percent change in jobcards among all GPs within study mandals. Row 4 presents the same but only among GPs sampled for our household survey. Standard errors are clustered at the mandal level. Statistical significance is denoted as: ${ }^{*} p<.10,{ }^{* *} p<.05,{ }^{* * *} p<.01$. 


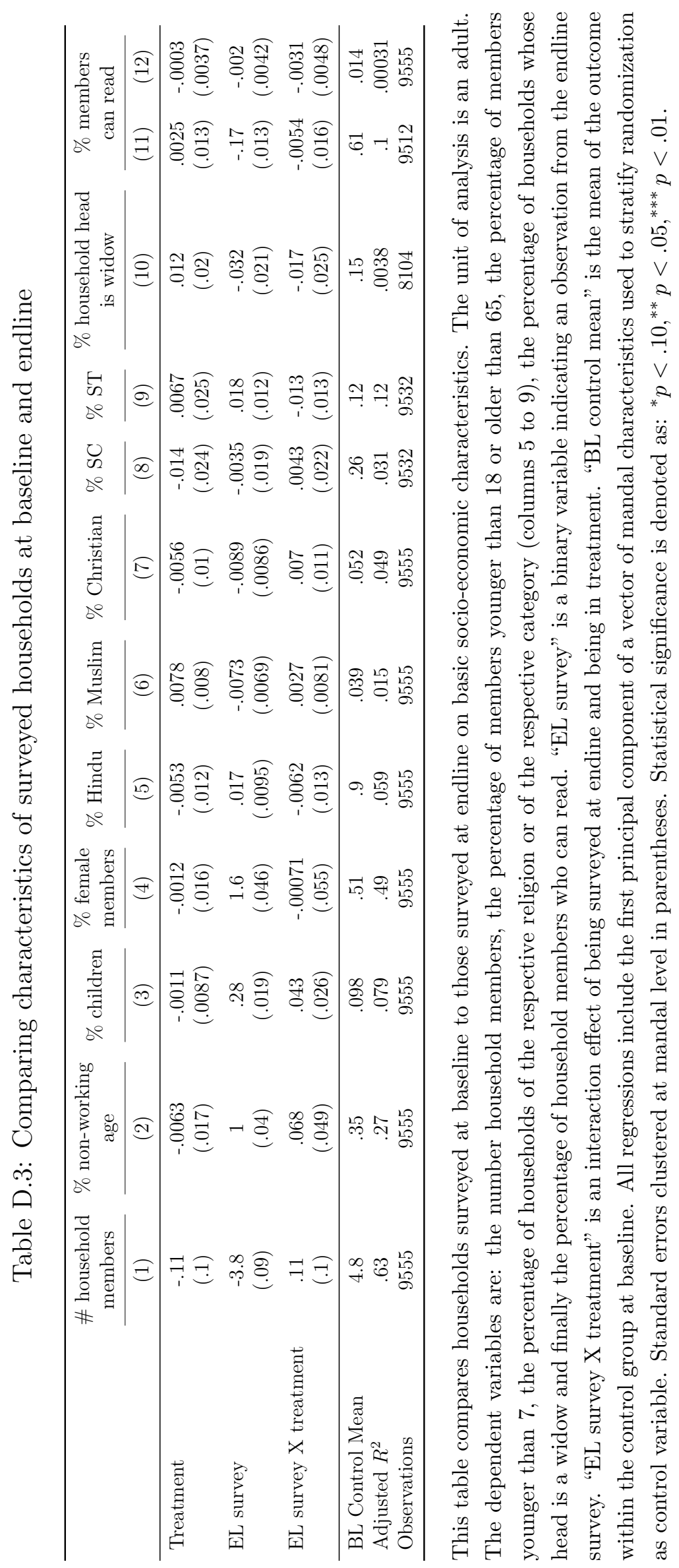




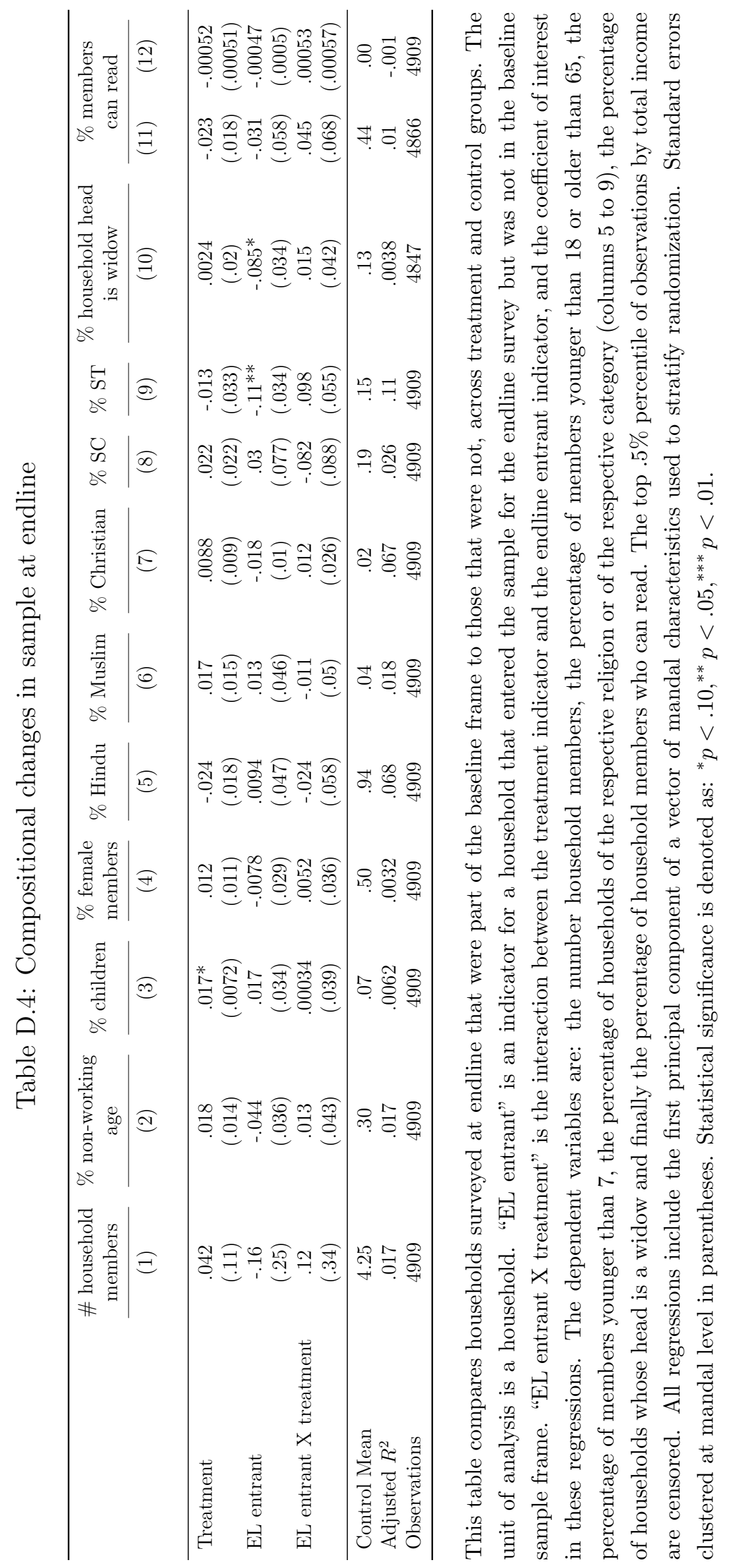




\section{E Workforce composition}

This appendix examines several issues related to the heterogeneous composition of the workforce.

We first provide additional descriptive information on the composition and time allocation of the adult population by gender and primary occupation (Table E.1). Note that a substantial proportion of both men (38\%) and women (39\%) do not identify working for money as their primary occupation. We include all adults in our sample when estimating labor market impacts as occupation is potentially endogenous to treatment, but note that this implies that overall time allocations reflect a mix of adults more or less attached to the labor force.

We next examine the robustness of our wage results to weighting observations by days worked rather than by worker. The resulting point estimates are moderately smaller than our main estimates but remain substantial and statistically significant (Table E.2).

We then examine to what extent the treatment effects on wages and reservation wages we estimate could be attributable to changes in the composition of the workforce as a result of treatment (Table E.3). (We cannot examine changes in the composition of tasks performed, as we do not observe measure of this.) In the first row we estimate treatment effects on a series of worker characteristics (age, gender, class, religion, Below Poverty Line status, being widow-led, and literacy) within the subsample of adults who report a positive number of days work. This specification thus captures treatment effects on the composition of the workforce. We find no individually significant changes, with small estimated effect sizes, and cannot reject the joint null of no effects ( $p=0.92$ from a Chi-squared test).

We nevertheless examine quantitatively how we might expect wage realizations to change given these (small) compositional changes. In rows 2 and 4 we examine how these characteristics are associated with wages earned and reservation wages, respectively, within the control group. Women earn lower wages and report lower reservation wages, and widow-led households also earn lower wages; other characteristics are not strongly associated with wages. Finally in rows 3 and 5 we calculate the product of the treatment effect on composition and the control group association to obtain the predicted compositional effect on wages, by characteristic in Columns 1-7 and in total in Column 8. We estimate very small net compositional effects. For wages the point estimate accounts for $3 \%$ of the estimated treatment effect in Table 2, and we can reject effects larger than $20 \%$ with $95 \%$ confidence. For reservation wages, the point estimate accounts for $2 \%$ of the estimated treatment effect and we can reject effects larger than $19 \%$. 
Table E.1: Time allocation by gender and primary occupation

\begin{tabular}{|c|c|c|c|c|c|c|}
\hline & Self-employment & NREGS & Private sector & Not working & $n$ \\
\hline & & (1) & (2) & (3) & (4) & (5) \\
\hline \multirow[t]{4}{*}{ Men } & Workers & 7.0 & 4.9 & 10.1 & 8.0 & 6536 \\
\hline & Students & 3.3 & 0.6 & 1.4 & 21.8 & 3078 \\
\hline & Housework & 0.0 & 1.9 & 0.1 & 25.7 & 23 \\
\hline & Retired & 8.0 & 0.2 & 0.1 & 25.3 & 865 \\
\hline \multirow[t]{4}{*}{ Women } & Workers & 4.8 & 6.3 & 8.2 & 10.8 & 6294 \\
\hline & Students & 1.1 & 0.2 & 0.7 & 25.5 & 2427 \\
\hline & Housework & 2.1 & 0.7 & 0.6 & 26.4 & 685 \\
\hline & Retired & 0.4 & 0.0 & 0.6 & 28.8 & 964 \\
\hline
\end{tabular}

The unit of analysis is an adult. This table shows a cross-table of survey respondents' reported number of days spent on primary activities by gender and primary occupation.

Table E.2: Additional labor market results

\section{Wage realization (Rs.) Self-employment (days) Not working (days)}

(1)

\begin{tabular}{lccc}
\hline Adjusted TE & $10^{* *}$ & -.54 & $-1.9^{* * *}$ \\
$\left(\beta_{T}+0.36 * \beta_{N}\right)$ & $(5)$ & $(.74)$ & $(.66)$ \\
& $\{5.2\}$ & $\{.77\}$ & $\{.71\}$ \\
Main effect & $7.9^{*}$ & -.58 & -.87 \\
$\left(\beta_{T}\right)$ & $(4.1)$ & $(.58)$ & $(.54)$ \\
& $\{4.1\}$ & $\{.61\}$ & $\{.57\}$ \\
Nbhd effect & 2.5 & .041 & $-.99^{* * *}$ \\
$\left(0.36 * \beta_{N}\right)$ & $(3)$ & $(.35)$ & $(.35)$ \\
& $\{3.1\}$ & $\{.33\}$ & $. .33\}$ \\
\hline Weighted by days worked & Yes & No & No \\
Control mean & 128 & 5.8 & .085 \\
Adjusted $R^{2}$ & .058 & .023 & 13926 \\
Observations & 6969 & 13715 &
\end{tabular}

The unit of analysis is an adult. In Column 1, we weight results by days worked. Estimation is as described in Section 2.3 . Standard errors in parentheses are clustered by mandal; those in brackets are spatial as in Conley (2008). Significance based on the former is denoted: ${ }^{*} p<.10,{ }^{* *} p<.05,{ }^{* * *} p<.01$. 


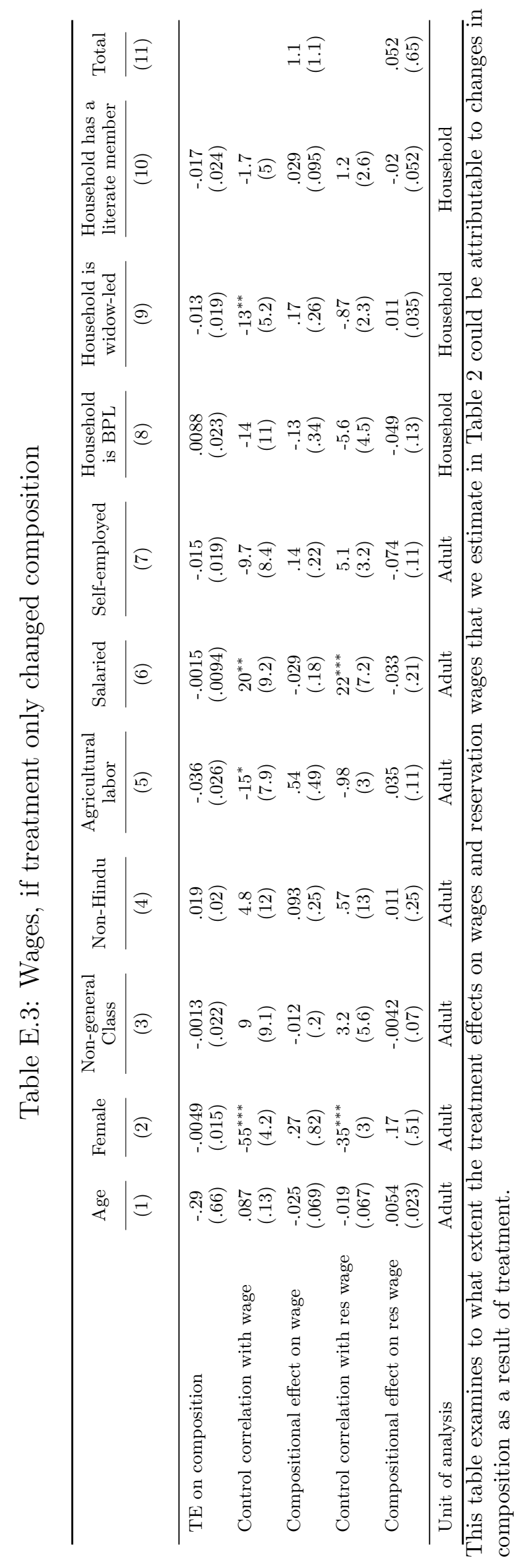




\section{F Robustness to alternative spatial specifications}

This appendix examines the sensitivity of our main spatially-adjusted estimates of the total effect of treatment on the treated (the "Adjusted TE") to alternative assumptions about how to model the relationship between outcomes in a GP and the treatment status of its neighbors.

\section{F.1 The handling of buffer mandals}

We default to treating GPs in mandals assigned to the second, "buffer" wave as control mandals when calculating neighborhood intensity measures. This is because, while we do not have information on the specific timing of treatment onset in each of these mandals, we know that treatment generally rolled out much later than in the treatment group (where even after two years only $50 \%$ of transactions were biometrically authenticated).

To examine sensitivity to this assumption we re-calculate results for our main outcomes under the alternative assumption that GPs in buffer mandals were treated $X \%$ as intensively as those in treatment mandals, for $X \% \in\{10 \%, \ldots, 50 \%\}$. Table F.1 reports the results. Qualitatively the results are very stable across these perturbations to the specification. Quantitatively we see for most outcomes a pattern of larger estimated effects for higher values of $X \%$, which suggests that our default specification may if anything slightly under-estimate total treatment effects on the treated.

\section{F.2 The selection of a radius}

By default we calculate neighborhood treatment intensity at a $20 \mathrm{~km}$ radius. We aim to use a radius that is large enough to plausibly capture spillovers effects due to labor market interactions, and thus in particular large enough to include distances over which a worker might plausibly travel to work. At a typical flat-surface human walking speed of $5 \mathrm{~km} /$ hour, the $20 \mathrm{~km}$ radius captures locations to which a worker could walk in 4 hours, which seems a reasonably conservative upper bound on the time a worker might be willing to commute for work. At a reasonably fast bicycling speed of $20 \mathrm{~km} / \mathrm{hour}$, it captures locations to which workers who own bicycles could travel in 1 hour. That said, results should be interpreted keeping in mind that effects may "ripple" across markets substantially farther than any individual worker might commute.

To examine sensitivity to this assumption, we also re-calculate results for our main outcomes under alternative assumptions about the spillover radius ranging from $R=10 \mathrm{~km}$ to $R=30 \mathrm{~km} 60$ Table F.2 reports the results. Point estimates and hypothesis tests are generally quite stable across these alternative assumptions. Effects on the indicator for land ownership are perhaps the one exception, as these are significant only for $R=20$ and $R=25$. For labor market outcomes there is some tendency towards both larger estimates and standard errors at higher values of $R$, which is consistent with the idea that higher values of $R$ capture spillovers more thoroughly but also with less experimental variation, as we apply the law of large numbers to averages taken over larger areas.

\footnotetext{
${ }^{60}$ In Egger et al. (2020) one of us took an alternative approach, pre-specifying an algorithmic approach to selecting an optimal radius using the data. That approach was motivated in part by the preliminary results from this project, which had been released before Egger et al. (2020) began data collection.
} 


\section{F.3 Additional sensitivity checks}

In Table F.3 we report the results of three additional sensitivity checks (with our main results reproduced in Column 1 for comparison).

In Column 2 we examine an alternative kernel function. By default we use a binary kernel, giving equal weight to the treatment status of all GPs within a given radius and no weight to those further away. This is our preferred approach as it is relatively easy to interpret and allows us to discipline the selection of the relevant parameter (i.e. the radius) using basic descriptive information about travel time and costs in our setting (see above). As a sensitivity check we also examine results using the smooth kernel $k(r)=(1+\alpha r)^{-\theta}$ to weight observations at distance $r$. In the context of "gravity" models of trade, $\alpha$ can be interpreted as the increase in the iceberg costs of trade per kilometer of distance, and $\theta$ as the elasticity of trade to total costs. Since the key commodity of interest here is labor, we set $\alpha$ as follows: suppose that workers can travel 20km / hour by bicyle and work for 10 hours per day; in this case commuting to a worksite an additional $1 \mathrm{~km}$ away reduces the proportion of the workday available for labor by $1 \%{ }^{61}$ Hence, we set $\alpha=1 / 100$. We set $\theta=8$ following Donaldson and Hornbeck (2016).

In Column 3 we examine an alternative treatment of same-mandal GPs. By default we exclude these GPs when calculating the intensity of treatment in the neighborhood of a given GP, as this lets us cleanly separate the two sources of experimental variation we use, and avoids the potential issue that neighborhood variables would by construction be differently related to proximity to borders in treatment and control mandals. To check sensitivity to this approach we also report estimates that include same-mandal villages in the calculation of neighborhood exposure measures.

Finally, in Column 4 we examine sensitivity to functional form. By default we model outcomes as linear in the share of treated neighbors, as we do not have strong priors that spillovers should exhibit either increasing or decreasing returns to scale at the margin. This specification is also comparable with other relevant examples in the literature such as Miguel and Kremer (2004) and Egger et al. (2020). Figure F.1 shows, consistent with this, that there is no obvious visual tendency towards non-linearity for key outcomes. To assess sensitivity to this approach we also report estimates based based on a quadratic specification.

Overall our results are reasonably robust to these variations, with a few exceptions. Using a smooth kernel, the effect on net earnings per acre and days worked in the private sector become insignificant while effects on SECC income variables all become significant. Including same-mandal villages in the regressor, effects on days worked in the private sector and on Economic Census outcomes become insignificant. Otherwise the patterns of statistical significance (and magnitude of the estimates) are reasonably consistent.

\footnotetext{
${ }^{61}$ The time cost is $2 \times 1 \mathrm{~km} / 20 \mathrm{~km} / \mathrm{hr}=1 / 10 \mathrm{hr}$, or $1 / 100$ of the workday.
} 
Table F.1: Adjusted treatment effects on key outcomes by buffer treatment assumption

\begin{tabular}{|c|c|c|c|c|c|c|}
\hline & Main specification & $\begin{array}{l}\text { Buffer is } \\
10 \% \text { treated }\end{array}$ & $\begin{array}{c}\text { Buffer is } \\
20 \% \text { treated }\end{array}$ & $\begin{array}{c}\text { Buffer is } \\
30 \% \text { treated }\end{array}$ & $\begin{array}{c}\text { Buffer is } \\
40 \% \text { treated }\end{array}$ & $\begin{array}{c}\text { Buffer is } \\
50 \% \text { treated }\end{array}$ \\
\hline & (1) & $(2)$ & (3) & $(4)$ & $(5)$ & (6) \\
\hline Total income & $\begin{array}{l}9579^{* *} \\
(4539)\end{array}$ & $\begin{array}{l}9602^{*} \\
(4930)\end{array}$ & $\begin{array}{l}9580^{*} \\
(5421)\end{array}$ & $\begin{array}{c}9488 \\
(6005)\end{array}$ & $\begin{array}{c}9297 \\
(6658)\end{array}$ & $\begin{array}{c}8980 \\
(7331)\end{array}$ \\
\hline Reservation wage & $\begin{array}{l}6.9^{* *} \\
(3.2)\end{array}$ & $\begin{array}{l}7.3^{* *} \\
(3.4)\end{array}$ & $\begin{array}{l}7.7^{* *} \\
(3.7)\end{array}$ & $\begin{array}{l}8.3^{* *} \\
(4.1)\end{array}$ & $\begin{array}{l}8.9^{*} \\
(4.6)\end{array}$ & $\begin{array}{l}9.5^{*} \\
(5)\end{array}$ \\
\hline Wage realization & $\begin{array}{c}13^{* * *} \\
(4.3)\end{array}$ & $\begin{array}{c}14^{* * *} \\
(4.6)\end{array}$ & $\begin{array}{c}15^{* * *} \\
(5)\end{array}$ & $\begin{array}{c}16^{* * *} \\
(5.6)\end{array}$ & $\begin{array}{c}17^{* * *} \\
(6.2)\end{array}$ & $\begin{array}{c}18^{* * *} \\
(6.8)\end{array}$ \\
\hline Days worked in private sector & $\begin{array}{l}1.4^{*} \\
(.8)\end{array}$ & $\begin{array}{l}1.6^{*} \\
(.88)\end{array}$ & $\begin{array}{l}1.8^{*} \\
(.97)\end{array}$ & $\begin{array}{l}1.9^{*} \\
(1.1)\end{array}$ & $\begin{array}{l}2.1^{*} \\
(1.2)\end{array}$ & $\begin{array}{l}2.2^{*} \\
(1.3)\end{array}$ \\
\hline Days worked in NREGS & $\begin{array}{l}1.3^{* *} \\
(.55)\end{array}$ & $\begin{array}{l}1.4^{* *} \\
(.59)\end{array}$ & $\begin{array}{l}1.5^{* *} \\
(.64)\end{array}$ & $\begin{array}{c}1.6^{* *} \\
(.7)\end{array}$ & $\begin{array}{l}1.7^{* *} \\
(.77)\end{array}$ & $\begin{array}{l}1.8^{* *} \\
(.85)\end{array}$ \\
\hline Days self-employed or not working & $\begin{array}{c}-2.4^{* * *} \\
(.79)\end{array}$ & $\begin{array}{c}-2.6^{* * *} \\
(.86)\end{array}$ & $\begin{array}{c}-2.8^{* * *} \\
(.94)\end{array}$ & $\begin{array}{c}-3.1^{* * *} \\
(1)\end{array}$ & $\begin{array}{c}-3.2^{* * *} \\
(1.1)\end{array}$ & $\begin{array}{c}-3.4^{* * *} \\
(1.2)\end{array}$ \\
\hline Log of Price Index (uniform goods) & $\begin{array}{l}-.055 \\
(.13)\end{array}$ & $\begin{array}{l}-.069 \\
(.14)\end{array}$ & $\begin{array}{l}-.085 \\
(.16)\end{array}$ & $\begin{array}{l}-.1 \\
(.19)\end{array}$ & $\begin{array}{l}-.13 \\
(.22)\end{array}$ & $\begin{array}{l}-.15 \\
(.25)\end{array}$ \\
\hline Log of Price Index (all goods) & $\begin{array}{l}.0059 \\
(.045)\end{array}$ & $\begin{array}{l}.008 \\
(.05)\end{array}$ & $\begin{array}{l}.012 \\
(.055)\end{array}$ & $\begin{array}{l}.018 \\
(.063)\end{array}$ & $\begin{array}{l}.028 \\
(.071)\end{array}$ & $\begin{array}{l}.043 \\
(.081)\end{array}$ \\
\hline Log of Individual Prices & $\begin{array}{c}-.0003 \\
(.016)\end{array}$ & $\begin{array}{l}.0019 \\
(.017)\end{array}$ & $\begin{array}{l}.0046 \\
(.018)\end{array}$ & $\begin{array}{l}.0078 \\
(.02)\end{array}$ & $\begin{array}{l}.012 \\
(.023)\end{array}$ & $\begin{array}{l}.017 \\
(.025)\end{array}$ \\
\hline Own-land profits & $\begin{array}{c}-.19^{* *} \\
(.08)\end{array}$ & $\begin{array}{l}-.21^{* *} \\
(.084)\end{array}$ & $\begin{array}{c}-.24^{* * *} \\
(.091)\end{array}$ & $\begin{array}{c}-.27^{* * *} \\
(.1)\end{array}$ & $\begin{array}{c}-.29^{* *} \\
(.11)\end{array}$ & $\begin{array}{c}-.32^{* *} \\
(.13)\end{array}$ \\
\hline Value per acre of land & $\begin{array}{l}-.06 \\
(.13)\end{array}$ & $\begin{array}{l}-.062 \\
(.14)\end{array}$ & $\begin{array}{l}-.065 \\
(.15)\end{array}$ & $\begin{array}{l}-.07 \\
(.17)\end{array}$ & $\begin{array}{l}-.077 \\
(.18)\end{array}$ & $\begin{array}{c}-.086 \\
(.2)\end{array}$ \\
\hline Lowest bracket $(<$ Rs. 5,000$)$ & $\begin{array}{l}-.028^{*} \\
(.017)\end{array}$ & $\begin{array}{l}-.029 \\
(.018)\end{array}$ & $\begin{array}{l}-.029 \\
(.02)\end{array}$ & $\begin{array}{l}-.031 \\
(.021)\end{array}$ & $\begin{array}{l}-.033 \\
(.023)\end{array}$ & $\begin{array}{l}-.037 \\
(.025)\end{array}$ \\
\hline Middle bracket (Rs. 5,000-10,000) & $\begin{array}{l}.025^{*} \\
(.014)\end{array}$ & $\begin{array}{l}.026^{*} \\
(.015)\end{array}$ & $\begin{array}{l}.027 \\
(.016)\end{array}$ & $\begin{array}{l}.028 \\
(.018)\end{array}$ & $\begin{array}{l}.029 \\
(.019)\end{array}$ & $\begin{array}{c}.03 \\
(.021)\end{array}$ \\
\hline Highest bracket (> Rs. 10,000) & $\begin{array}{l}.0034 \\
(.0069)\end{array}$ & $\begin{array}{c}.003 \\
(.0073)\end{array}$ & $\begin{array}{c}.003 \\
(.0078)\end{array}$ & $\begin{array}{l}.0036 \\
(.0082)\end{array}$ & $\begin{array}{l}.005 \\
(.0085)\end{array}$ & $\begin{array}{c}.0074 \\
(.0086)\end{array}$ \\
\hline Income bracket 3 levels & $\begin{array}{l}-.026 \\
(.017)\end{array}$ & $\begin{array}{l}-.026 \\
(.018)\end{array}$ & $\begin{array}{l}-.027 \\
(.019)\end{array}$ & $\begin{array}{l}-.028 \\
(.021)\end{array}$ & $\begin{array}{l}-.031 \\
(.023)\end{array}$ & $\begin{array}{l}-.035 \\
(.024)\end{array}$ \\
\hline All enterprises & $\begin{array}{l}1095^{*} \\
(575)\end{array}$ & $\begin{array}{l}1166^{*} \\
(610)\end{array}$ & $\begin{array}{c}1257^{*} \\
(649)\end{array}$ & $\begin{array}{c}1371^{* *} \\
(690)\end{array}$ & $\begin{array}{c}1505^{* *} \\
(729)\end{array}$ & $\begin{array}{c}1653^{* *} \\
(764)\end{array}$ \\
\hline All employees & $\begin{array}{l}3307^{* *} \\
(1554)\end{array}$ & $\begin{array}{l}3562^{* *} \\
(1663)\end{array}$ & $\begin{array}{l}3867^{* *} \\
(1787)\end{array}$ & $\begin{array}{l}4221^{* *} \\
(1924)\end{array}$ & $\begin{array}{l}4609^{* *} \\
(2069)\end{array}$ & $\begin{array}{l}4999^{* *} \\
(2214)\end{array}$ \\
\hline Total savings (Rs.) & $\begin{array}{c}260 \\
(322)\end{array}$ & $\begin{array}{c}325 \\
(344)\end{array}$ & $\begin{array}{c}402 \\
(374)\end{array}$ & $\begin{array}{c}492 \\
(415)\end{array}$ & $\begin{array}{c}591 \\
(466)\end{array}$ & $\begin{array}{c}690 \\
(526)\end{array}$ \\
\hline Total loans (Rs.) & $\begin{array}{c}20400^{* * *} \\
(6403)\end{array}$ & $\begin{array}{c}22638^{* * *} \\
(7028)\end{array}$ & $\begin{array}{c}25135^{* * *} \\
(7838)\end{array}$ & $\begin{array}{c}27797^{* * *} \\
(8858)\end{array}$ & $\begin{array}{c}30419^{* * *} \\
(10080)\end{array}$ & $\begin{array}{c}32643^{* * *} \\
(11448)\end{array}$ \\
\hline Owns land (\%) & $\begin{array}{l}.072^{* *} \\
(.033)\end{array}$ & $\begin{array}{l}.074^{* *} \\
(.036)\end{array}$ & $\begin{array}{l}.076^{*} \\
(.04)\end{array}$ & $\begin{array}{l}.076^{*} \\
(.044)\end{array}$ & $\begin{array}{l}.076 \\
(.049)\end{array}$ & $\begin{array}{l}.072 \\
(.054)\end{array}$ \\
\hline Survey: annualized expenditure (Rs. per year) & $\begin{array}{c}389 \\
(4676)\end{array}$ & $\begin{array}{c}941 \\
(5090)\end{array}$ & $\begin{array}{c}1646 \\
(5636)\end{array}$ & $\begin{array}{c}2525 \\
(6327)\end{array}$ & $\begin{array}{c}3577 \\
(7165)\end{array}$ & $\begin{array}{c}4758 \\
(8122)\end{array}$ \\
\hline NSS: annualized expenditure (Rs. per year) & $\begin{array}{c}18105 \\
(13106)\end{array}$ & $\begin{array}{c}17024 \\
(14592)\end{array}$ & $\begin{array}{c}15203 \\
(16507)\end{array}$ & $\begin{array}{c}12316 \\
(18920)\end{array}$ & $\begin{array}{c}7952 \\
(21855)\end{array}$ & $\begin{array}{c}1664 \\
(25220)\end{array}$ \\
\hline
\end{tabular}

Refer to Tables 1, 2, 3, 4, 5, and 7 for the corresponding main specification tables. Standard errors in parentheses are clustered by mandal. Statistical significance is denoted: ${ }^{*} p<.10,{ }^{* *} p<.05,{ }^{* * *} p<.01$. 
Table F.2: Adjusted treatment effects on key outcomes by spillover radius assumption

\begin{tabular}{|c|c|c|c|c|c|}
\hline & $\frac{R=10}{(1)}$ & $\frac{\mathrm{R}=15}{(2)}$ & $\begin{array}{c}\mathrm{R}=20 \\
\text { Main specification }\end{array}$ & $\frac{\mathrm{R}=25}{(4)}$ & $\frac{\mathrm{R}=30}{(5)}$ \\
\hline Total income & $\begin{array}{c}10377^{* *} \\
(4280)\end{array}$ & $\begin{array}{l}9789^{* *} \\
(4173)\end{array}$ & $\begin{array}{l}9579^{* *} \\
(4539)\end{array}$ & $\begin{array}{l}9732^{*} \\
(5071)\end{array}$ & $\begin{array}{l}10027^{*} \\
(5551)\end{array}$ \\
\hline Reservation wage & $\begin{array}{l}6.5^{* *} \\
(2.9)\end{array}$ & $\begin{array}{l}7.3^{* *} \\
(2.9)\end{array}$ & $\begin{array}{l}6.9^{* *} \\
(3.2)\end{array}$ & $\begin{array}{l}6.7^{*} \\
(3.4)\end{array}$ & $\begin{array}{l}6.3^{*} \\
(3.7)\end{array}$ \\
\hline Wage realization & $\begin{array}{c}13^{* * *} \\
(3.8)\end{array}$ & $\begin{array}{c}13^{* * *} \\
(3.9)\end{array}$ & $\begin{array}{c}13^{* * *} \\
(4.3)\end{array}$ & $\begin{array}{c}13^{* * *} \\
(4.7)\end{array}$ & $\begin{array}{c}14^{* * *} \\
(5.1)\end{array}$ \\
\hline Days worked in private sector & $\begin{array}{c}1.1 \\
(.69)\end{array}$ & $\begin{array}{l}1.3^{*} \\
(.74)\end{array}$ & $\begin{array}{l}1.4^{*} \\
(.8)\end{array}$ & $\begin{array}{l}1.7^{* *} \\
(.85)\end{array}$ & $\begin{array}{l}2^{* *} \\
(.91)\end{array}$ \\
\hline Days worked in NREGS & $\begin{array}{l}1.1^{* *} \\
(.53)\end{array}$ & $\begin{array}{l}1.3^{* *} \\
(.56)\end{array}$ & $\begin{array}{l}1.3^{* *} \\
(.55)\end{array}$ & $\begin{array}{l}1.4^{* *} \\
(.56)\end{array}$ & $\begin{array}{c}1.4^{* *} \\
(.6)\end{array}$ \\
\hline Days self-employed or not working & $\begin{array}{l}-2^{* * *} \\
(.68)\end{array}$ & $\begin{array}{c}-2.3^{* * *} \\
(.71)\end{array}$ & $\begin{array}{c}-2.4^{* * *} \\
(.79)\end{array}$ & $\begin{array}{c}-2.7^{* * *} \\
(.84)\end{array}$ & $\begin{array}{c}-3^{* * *} \\
(.9)\end{array}$ \\
\hline Log of Price Index (uniform goods) & $\begin{array}{l}.024 \\
(.065)\end{array}$ & $\begin{array}{l}-.03 \\
(.11)\end{array}$ & $\begin{array}{l}-.055 \\
(.13)\end{array}$ & $\begin{array}{l}-.11 \\
(.14)\end{array}$ & $\begin{array}{l}-.082 \\
(.14)\end{array}$ \\
\hline Log of Price Index (all goods) & $\begin{array}{l}.0026 \\
(.029)\end{array}$ & $\begin{array}{l}-.0011 \\
(.038)\end{array}$ & $\begin{array}{l}.0059 \\
(.045)\end{array}$ & $\begin{array}{l}.0099 \\
(.05)\end{array}$ & $\begin{array}{c}-.00067 \\
(.054)\end{array}$ \\
\hline Log of Individual Prices & $\begin{array}{l}.0098 \\
(.015)\end{array}$ & $\begin{array}{l}.0047 \\
(.015)\end{array}$ & $\begin{array}{l}-.0003 \\
(.016)\end{array}$ & $\begin{array}{l}-.0069 \\
(.018)\end{array}$ & $\begin{array}{l}-.019 \\
(.021)\end{array}$ \\
\hline Own-land profits & $\begin{array}{c}-.13 \\
(.083)\end{array}$ & $\begin{array}{l}-.16^{*} \\
(.082)\end{array}$ & $\begin{array}{c}-.19^{* *} \\
(.08)\end{array}$ & $\begin{array}{l}-.19^{* *} \\
(.084)\end{array}$ & $\begin{array}{l}-.15 \\
(.09)\end{array}$ \\
\hline Value per acre of land & $\begin{array}{l}-.037 \\
(.12)\end{array}$ & $\begin{array}{l}-.066 \\
(.12)\end{array}$ & $\begin{array}{l}-.06 \\
(.13)\end{array}$ & $\begin{array}{l}-.021 \\
(.13)\end{array}$ & $\begin{array}{l}.042 \\
(.14)\end{array}$ \\
\hline Lowest bracket (< Rs. 5,000) & $\begin{array}{c}-.033^{* *} \\
(.015)\end{array}$ & $\begin{array}{c}-.032^{* *} \\
(.015)\end{array}$ & $\begin{array}{c}-.028^{*} \\
(.017)\end{array}$ & $\begin{array}{c}-.033^{*} \\
(.017)\end{array}$ & $\begin{array}{c}-.036^{* *} \\
(.018)\end{array}$ \\
\hline Middle bracket (Rs. 5,000-10,000) & $\begin{array}{l}.027^{* *} \\
(.012)\end{array}$ & $\begin{array}{l}.025^{*} \\
(.013)\end{array}$ & $\begin{array}{l}.025^{*} \\
(.014)\end{array}$ & $\begin{array}{l}.028^{*} \\
(.015)\end{array}$ & $\begin{array}{l}.031^{* *} \\
(.015)\end{array}$ \\
\hline Highest bracket (> Rs. 10,000) & $\begin{array}{l}.0057 \\
(.0058)\end{array}$ & $\begin{array}{l}.0065 \\
(.006)\end{array}$ & $\begin{array}{l}.0034 \\
(.0069)\end{array}$ & $\begin{array}{c}.0049 \\
(.0066)\end{array}$ & $\begin{array}{l}.0038 \\
(.007)\end{array}$ \\
\hline Income bracket 3 levels & $\begin{array}{c}-.032^{* *} \\
(.015)\end{array}$ & $\begin{array}{c}-.031^{* *} \\
(.015)\end{array}$ & $\begin{array}{l}-.026 \\
(.017)\end{array}$ & $\begin{array}{l}-.031^{*} \\
(.017)\end{array}$ & $\begin{array}{c}-.034^{*} \\
(.018)\end{array}$ \\
\hline All enterprises & $\begin{array}{l}1160^{*} \\
(618)\end{array}$ & $\begin{array}{l}1009^{*} \\
(583)\end{array}$ & $\begin{array}{l}1095^{*} \\
(575)\end{array}$ & $\begin{array}{l}1079^{*} \\
(569)\end{array}$ & $\begin{array}{c}826 \\
(538)\end{array}$ \\
\hline All employees & $\begin{array}{c}3278^{* *} \\
(1613) \\
\end{array}$ & $\begin{array}{c}3085^{* *} \\
(1534) \\
\end{array}$ & $\begin{array}{r}3307^{* *} \\
(1554) \\
\end{array}$ & $\begin{array}{r}3256^{* *} \\
(1528) \\
\end{array}$ & $\begin{array}{l}2663^{*} \\
(1405) \\
\end{array}$ \\
\hline Total savings (Rs.) & $\begin{array}{c}455 \\
(345)\end{array}$ & $\begin{array}{c}325 \\
(327)\end{array}$ & $\begin{array}{c}260 \\
(322)\end{array}$ & $\begin{array}{c}269 \\
(358)\end{array}$ & $\begin{array}{c}290 \\
(388)\end{array}$ \\
\hline Total loans (Rs.) & $\begin{array}{c}15668^{* * *} \\
(5975)\end{array}$ & $\begin{array}{c}16246^{* * *} \\
(6281)\end{array}$ & $\begin{array}{c}20400^{* * *} \\
(6403)\end{array}$ & $\begin{array}{c}22578^{* * *} \\
(6356)\end{array}$ & $\begin{array}{c}23030^{* * * *} \\
(6391)\end{array}$ \\
\hline Owns land (\%) & $\begin{array}{l}.031 \\
(.03)\end{array}$ & $\begin{array}{l}.045 \\
(.031)\end{array}$ & $\begin{array}{l}.072^{* *} \\
(.033)\end{array}$ & $\begin{array}{l}.072^{* *} \\
(.036)\end{array}$ & $\begin{array}{l}.054 \\
(.038)\end{array}$ \\
\hline Survey: annualized expenditure (Rs. per year) & $\begin{array}{c}725 \\
(3783)\end{array}$ & $\begin{array}{c}-66 \\
(4191)\end{array}$ & $\begin{array}{c}389 \\
(4676)\end{array}$ & $\begin{array}{c}1924 \\
(5166)\end{array}$ & $\begin{array}{c}3493 \\
(5525)\end{array}$ \\
\hline NSS: annualized expenditure (Rs. per year) & $\begin{array}{c}7905 \\
(8561)\end{array}$ & $\begin{array}{c}13333 \\
(11863)\end{array}$ & $\begin{array}{c}18105 \\
(13106)\end{array}$ & $\begin{array}{c}18398 \\
(14498)\end{array}$ & $\begin{array}{c}22492 \\
(16149)\end{array}$ \\
\hline
\end{tabular}

Refer to Tables 1, 2, 3, 4, 5, and 7 for the corresponding main specification tables. Standard errors in parentheses are clustered by mandal. Statistical significance is denoted: ${ }^{*} p<.10,{ }^{* *} p<.05,{ }^{* * *} p<.01$. 
Table F.3: Adjusted treatment effects on key outcomes using alternative spatial approaches

\begin{tabular}{|c|c|c|c|c|}
\hline & $\frac{\text { Main specification }}{(1)}$ & $\frac{\text { Smooth kernel }}{(2)}$ & $\frac{\begin{array}{c}\text { Same-mandal } \\
\text { villages included }\end{array}}{(3)}$ & $\frac{\text { Functional form }}{(4)}$ \\
\hline Total income & $\begin{array}{l}9579^{* *} \\
(4539)\end{array}$ & $\begin{array}{c}9325^{* *} \\
(3920)\end{array}$ & $\begin{array}{l}9410^{* *} \\
(4236)\end{array}$ & $\begin{array}{l}8994^{*} \\
(5378)\end{array}$ \\
\hline Reservation wage & $\begin{array}{l}6.9^{* *} \\
(3.2)\end{array}$ & $\begin{array}{l}5.3^{* *} \\
(2.7)\end{array}$ & $\begin{array}{l}7.9^{* *} \\
(3.1)\end{array}$ & $\begin{array}{c}9.1^{* * *} \\
(3.5)\end{array}$ \\
\hline Wage realization & $\begin{array}{c}13^{* * *} \\
(4.3)\end{array}$ & $\begin{array}{l}8.4^{* *} \\
(3.7)\end{array}$ & $\begin{array}{l}11^{* *} \\
(4.6)\end{array}$ & $\begin{array}{c}16^{* * *} \\
(5)\end{array}$ \\
\hline Days worked in private sector & $\begin{array}{l}1.4^{*} \\
(.8)\end{array}$ & $\begin{array}{l}.8 \\
(.55)\end{array}$ & $\begin{array}{c}1.1 \\
(.79)\end{array}$ & $\begin{array}{l}1.6^{* *} \\
(.81)\end{array}$ \\
\hline Days worked in NREGS & $\begin{array}{l}1.3^{* *} \\
(.55)\end{array}$ & $\begin{array}{l}.85^{*} \\
(.49)\end{array}$ & $\begin{array}{l}1^{*} \\
(.55)\end{array}$ & $\begin{array}{c}1.6^{* * *} \\
(.59)\end{array}$ \\
\hline Days self-employed or not working & $\begin{array}{c}-2.4^{* * *} \\
(.79)\end{array}$ & $\begin{array}{c}-1.5^{* * *} \\
(.57)\end{array}$ & $\begin{array}{l}-2^{* * *} \\
(.79)\end{array}$ & $\begin{array}{c}-2.7^{* * *} \\
(.81)\end{array}$ \\
\hline Log of Price Index (uniform goods) & $\begin{array}{l}-.055 \\
(.13)\end{array}$ & $\begin{array}{l}.0048 \\
(.069)\end{array}$ & $\begin{array}{l}-.045 \\
(.099)\end{array}$ & $\begin{array}{c}-.0071 \\
(.15)\end{array}$ \\
\hline Log of Price Index (all goods) & $\begin{array}{l}.0059 \\
(.045)\end{array}$ & $\begin{array}{l}.012 \\
(.026)\end{array}$ & $\begin{array}{l}.014 \\
(.033)\end{array}$ & $\begin{array}{l}.015 \\
(.058)\end{array}$ \\
\hline Log of Individual Prices & $\begin{array}{l}-.0003 \\
(.016)\end{array}$ & $\begin{array}{l}-.0065 \\
(.011)\end{array}$ & $\begin{array}{l}.0022 \\
(.013)\end{array}$ & $\begin{array}{c}-.02 \\
(.028)\end{array}$ \\
\hline Own-land income & $\begin{array}{c}-.19^{* *} \\
(.08)\end{array}$ & $\begin{array}{l}-.079 \\
(.078)\end{array}$ & $\begin{array}{l}-.2^{* *} \\
(.079)\end{array}$ & $\begin{array}{c}-.19^{* *} \\
(.092)\end{array}$ \\
\hline Value per acre of land & $\begin{array}{l}-.06 \\
(.13)\end{array}$ & $\begin{array}{c}-.062 \\
(.1)\end{array}$ & $\begin{array}{l}-.11 \\
(.13)\end{array}$ & $\begin{array}{r}-.022 \\
(.14)\end{array}$ \\
\hline Lowest bracket (< Rs. 5,000) & $\begin{array}{c}-.028^{*} \\
(.017)\end{array}$ & $\begin{array}{c}-.034^{* *} \\
(.014)\end{array}$ & $\begin{array}{l}-.025 \\
(.017)\end{array}$ & $\begin{array}{c}-.032^{*} \\
(.018)\end{array}$ \\
\hline Middle bracket (Rs. 5,000-10,000) & $\begin{array}{l}.025^{*} \\
(.014)\end{array}$ & $\begin{array}{l}.024^{* *} \\
(.011)\end{array}$ & $\begin{array}{l}.023 \\
(.014)\end{array}$ & $\begin{array}{l}.027^{*} \\
(.015)\end{array}$ \\
\hline Highest bracket (> Rs. 10,000) & $\begin{array}{c}.0034 \\
(.0069)\end{array}$ & $\begin{array}{l}.0095^{*} \\
(.0055)\end{array}$ & $\begin{array}{c}.0032 \\
(.0067)\end{array}$ & $\begin{array}{c}.0052 \\
(.0078)\end{array}$ \\
\hline Income bracket 3 levels & $\begin{array}{l}-.026 \\
(.017)\end{array}$ & $\begin{array}{c}-.034^{* *} \\
(.014)\end{array}$ & $\begin{array}{l}-.023 \\
(.017)\end{array}$ & $\begin{array}{l}-.031^{*} \\
(.018)\end{array}$ \\
\hline All enterprises & $\begin{array}{l}1095^{*} \\
(575)\end{array}$ & $\begin{array}{l}853^{*} \\
(445)\end{array}$ & $\begin{array}{c}513 \\
(642)\end{array}$ & $\begin{array}{l}1405^{*} \\
(757)\end{array}$ \\
\hline All employees & $\begin{array}{r}3307^{* *} \\
(1554)\end{array}$ & $\begin{array}{c}2468^{* *} \\
(1247)\end{array}$ & $\begin{array}{c}1485 \\
(1791)\end{array}$ & $\begin{array}{c}3307^{* *} \\
(1554)\end{array}$ \\
\hline Total savings (Rs.) & $\begin{array}{c}260 \\
(322)\end{array}$ & $\begin{array}{l}-12 \\
(284)\end{array}$ & $\begin{array}{c}1.0 \mathrm{e}+02 \\
(316)\end{array}$ & $\begin{array}{l}612^{*} \\
(352)\end{array}$ \\
\hline Total loans (Rs.) & $\begin{array}{c}20400^{* * *} \\
(6403)\end{array}$ & $\begin{array}{c}10658^{* *} \\
(5076)\end{array}$ & $\begin{array}{c}20036^{* * *} \\
(6326)\end{array}$ & $\begin{array}{c}26047^{* * *} \\
(7744)\end{array}$ \\
\hline Owns land (\%) & $\begin{array}{l}.072^{* *} \\
(.033)\end{array}$ & $\begin{array}{l}.048^{* *} \\
(.024)\end{array}$ & $\begin{array}{l}.059^{*} \\
(.032)\end{array}$ & $\begin{array}{c}.097^{* * *} \\
(.036)\end{array}$ \\
\hline Survey: annualized expenditure (Rs. per year) & $\begin{array}{c}389 \\
(4676)\end{array}$ & $\begin{array}{l}-563 \\
(835)\end{array}$ & $\begin{array}{l}2687 \\
(5051)\end{array}$ & $\begin{array}{c}2914 \\
(5167)\end{array}$ \\
\hline NSS: annualized expenditure (Rs. per year) & $\begin{array}{c}18105 \\
(13106)\end{array}$ & $\begin{array}{l}14120 \\
(8862)\end{array}$ & $\begin{array}{l}18110^{*} \\
(9992)\end{array}$ & $\begin{array}{c}21655 \\
(13464)\end{array}$ \\
\hline
\end{tabular}

Refer to Tables 1, 2, 3, 4, 5, and 7 for the corresponding main specification tables. Standard errors in parentheses are clustered by mandal. Statistical significance is denoted: ${ }^{*} p<.10,{ }^{* *} p<.05,{ }^{* * *} p<.01$. 


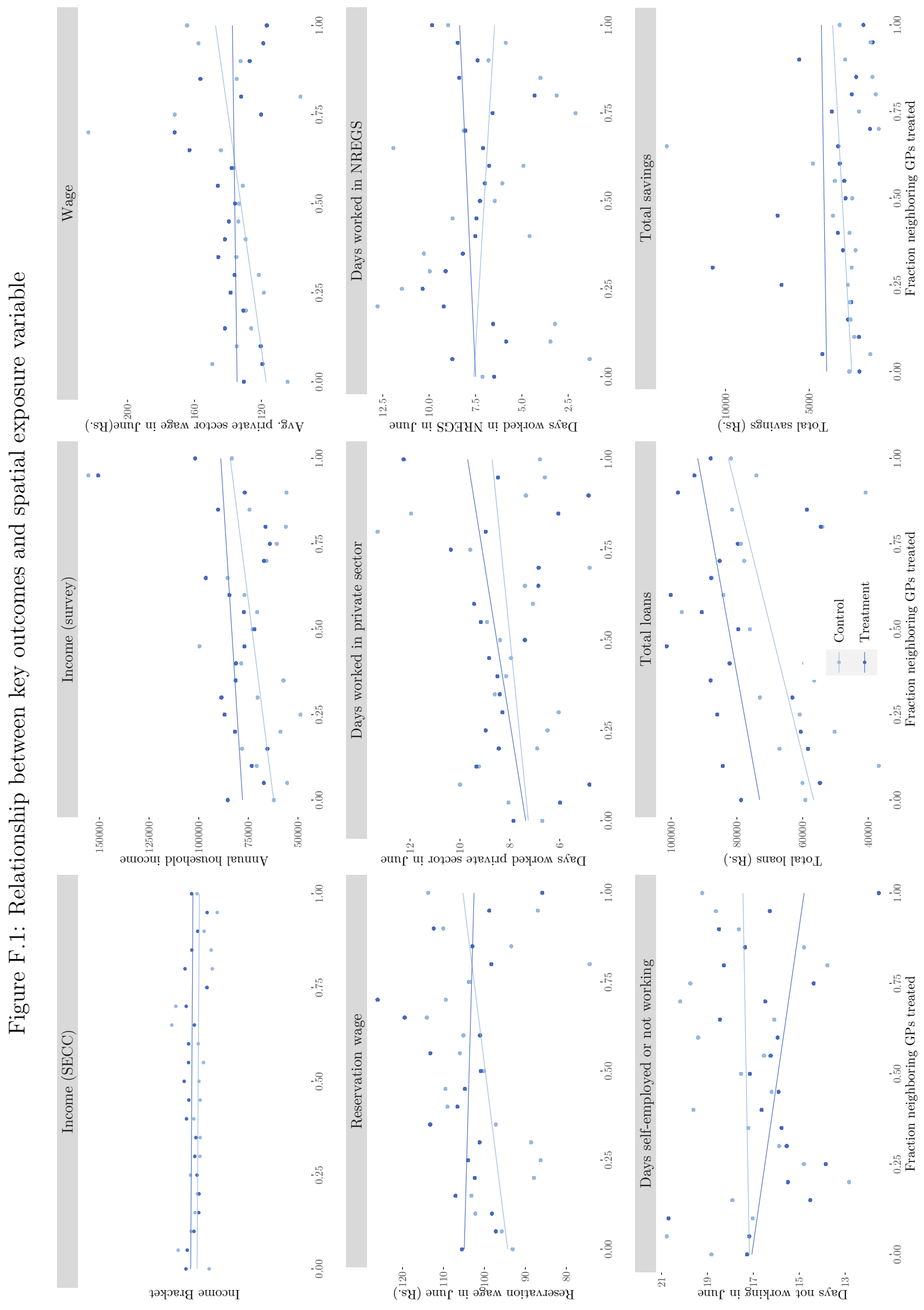




\section{G Labor market comparative statics}

This appendix derives comparative statics for the effects of an improvement in the NREGS on private sector labor market outcomes, considering both the benchmark case of perfect competition and also the case of imperfect competition on the employer side of the market. The framework also allows us to quantitatively assess the extent to which an improved NREGS could affect labor productivity by contributing to an increase in the rural capital stock. Finally, we examine how an improved NREGS could affect returns to land under the same range of alternative assumptions.

\section{G.1 Labor supply}

We first examine properties of the labor supply curve; note that these hold irrespective of market structure on the employer side. Consider a unit mass of workers each of whom decides whether to work in the private sector, on the NREGS, or neither (e.g. to engage in self-employment or leisure). Privatesector jobs pay a wage $w$, while NREGS jobs are characterized by a parameter $\theta$ which captures various non-wage aspects of job quality, such as the likelihood of getting work, and the speed and reliability of getting paid. Viewed through the lens of this model, our empirical results are the reduced-form effects of a discrete increase in $\theta$ (which we do not directly observe) induced by the Smartcards reform. Here we interpret $\theta$ as continuous to facilitate the derivation of comparative statics.

Define worker $i$ 's reservation wage $r(i, \theta)$ as the lowest private sector wage such that he prefers to work in the private sector. This depends on characteristics of NREGS jobs-including those captured by $\theta$ and potentially others such as the location, NREGS wage, the intensity of effort required, etc.and may vary by individual, as different workers have different self-employment options and different tastes for NREGS or private-sector work. Let individuals be ordered by their reservation wage, so that $i \geq i^{\prime} \leftrightarrow r(i, \theta) \geq r\left(i^{\prime}, \theta\right)$. Let $i^{*}(w, \theta)$ denote the marginal worker who is just indifferent between working in the private sector or not for a given schedule $(w, \theta)$, defined implicitly by

$$
r\left(i^{*}(w, \theta), \theta\right)=w
$$

Then we can write the labor supply curve simply as

$$
L(w, \theta)=i^{*}(w, \theta)
$$

i.e. the share of the population who choose to work in the private sector is equal to the index value of the marginal worker. Assuming differentiability, and differentiating (5) and substituting for $i^{*}$ using (6), we obtain the following expression for the total effect of improving the NREGS on private sector employment:

$$
\frac{d L}{d \theta}=\frac{1}{\partial r\left(i^{*}, \theta\right) / \partial i}\left[\frac{d w}{d \theta}-\frac{\partial r\left(i^{*}, \theta\right)}{\partial \theta}\right]
$$

From this we see the intuitive result that private sector employment (regardless of demand-side market structure) increases, decreases, or does not change depending on whether improving the NREGS has an impact on private sector wages that is greater than, less than, or equal to the impact on the reservation wage of the marginal worker. Note that in our data we do indeed see larger increases in mean wages (Rs. 13) than in mean reservation wages (Rs. 6.9), consistent with employment gains.

The same logic also implies that the changes in wages and employment we observe in our data do not on their own identify the elasticity of labor supply, precisely because reservation wages are simultaneously 
affected. To see this more explicitly, rewrite (7) as

$$
\frac{w}{L} \frac{d L / d \theta}{d w / d \theta}=\epsilon \cdot\left[1-\frac{\partial r\left(i^{*}, \theta\right) / \partial \theta}{d w / d \theta}\right]
$$

where

$$
\epsilon:=\frac{w}{L} \frac{\partial L}{\partial w}
$$

is the wage elasticity of aggregate labor supply. Equation (8) shows that the observed relationship between employment and wages is downwards-biased as an estimate of the supply elasticity with the magnitude of the bias depending on relatively magnitudes of the effects on reservation wages and actual wages. Since we observe treatment effects on reservation wages, however, we can estimate this term directly (using the adjusted treatment effects from Table 2) and thus recover an estimate of $\epsilon$. Combining these with control-group mean values of $w$ and $L$ and the estimated treatment effects on $L$ and $w$, we recover an estimated elasticity of $\epsilon=3.07$, albeit with a wide confidence interval (with 95\% confidence interval of $[-3.89,10.03]) 62$ Note that this is the elasticity of overall labor supply to the private sector conditional on the presence of the NREGS as a potential alternative, and we should thus expect it to be higher than overall elasticity of labor supply to any form of employment, or the elasticity of labor supply to the private sector in the absence of the NREGS.

\section{G.2 Labor demand}

We next introduce a production function and examine the labor demand and market equilibrium conditions this produces under the alternative assumptions that wages equal the marginal product of labor, as under perfect competition, or that wages are as if set by a single, monopsonistic employer. In each case we examine what must hold quantitatively to fit these assumptions to our data, and what our data then imply about underlying elasticities.

Let the revenue product of labor be given by $f(L, \theta)$, so that private-sector profits are

$$
\pi(w, L, \theta):=f(L, \theta)-w L
$$

where $f$ is increasing $\left(f_{L}>0\right)$ with decreasing returns $\left(f_{L L}<0\right)$ in $L$. We allow $f$ to depend directly on $\theta$ in order to capture the possibility that improvements to the NREGS could have positive externalities on private-sector labor productivity, as for example through the creation of public assets (roads, irrigation).

\section{G.2.1 Perfect competition}

Consider first the benchmark case in which wages (and thus the reservation wage of the marginal worker) equal the marginal revenue product of labor:

$$
f_{L}(L, \theta)=w=r\left(i^{*}(w, \theta), \theta\right)
$$

In this case, higher wages must be associated with lower employment (which raises $f_{L}$ ) unless corresponding changes in $\theta$ directly increase $f_{L}$. In economic terms, employment can increase in response

\footnotetext{
${ }^{62}$ The variance of this estimate is driven by the fact that we cannot reject the hypothesis that $\partial r / \partial \theta=d w / d \theta$, and thus that the factor we divide by to solve 8 for $\epsilon$ is close to zero.
} 
to NREGS improvements that raise wages only if those improvements also increase labor productivity enough to more than offset the higher costs of labor. Mathematically,

$$
\frac{d w}{d \theta}=\frac{f_{L L} L_{\theta}+f_{L \theta}}{1-f_{L L} L_{w}} \quad \frac{d L}{d \theta}=\frac{L_{\theta}+f_{L \theta} L_{w}}{1-f_{L L} L_{w}}
$$

The market wage effect here is positive (provided only that $f_{L \theta}$ is not too negative - note that we expect $f_{L \theta}$ to be positive), while the employment effect is negative unless the second term in the numerator is sufficiently positive to offset the first - in other words, if the increase in labor productivity $f_{L \theta}$ times the responsiveness of labor supply to market wages $L_{w}$ is greater than its responsiveness to NREGS wages $L_{\theta}$.

The net effect of $\theta$ on profits $\pi$ is generally ambiguous, since $\theta$ may both raise the productivity and increase the opportunity cost of labor. If we interpret $\theta$ as a pure labor productivity shift, however, then it unambiguously increases profits. Specifically, letting $f(L, \theta)=f(\theta L)$ and $L_{\theta}=0$, we have

$$
\frac{d \pi}{d \theta}=L \cdot\left[f^{\prime}(\theta L)-\frac{d w}{d \theta}\right]=-L f^{\prime \prime}(\theta L) \cdot\left[\frac{\theta L+\theta^{2} f^{\prime}(\theta L) L_{w}}{1-\theta^{2} f^{\prime \prime}(\theta L) L_{w}}\right] \geq 0
$$

where the last inequality follows from $f^{\prime \prime} \leq 0$

One consequence of the fact that labor productivity must increase to explain our results under perfect competition is that we cannot identify a labor demand elasticity in this case. To see this, note that the demand elasticity is $\epsilon^{D}=\frac{w}{L} \frac{1}{f_{L L}}$ and so is identified if and only if $f_{L L}$ is identified. In our data we do not observe $\theta$ and so do not observe $d w / d \theta$ or $d L / d \theta$ individually, but do observe the ratio of these quantities, i.e.

$$
\frac{d w / d \theta}{d L / d \theta}=\frac{f_{L L} L_{\theta}+f_{L \theta}}{L_{\theta}+f_{L \theta} L_{w}}
$$

If $f_{L \theta}=0$ then this identifies $f_{L L}$, but in this case employment is (counterfactually) predicted to fall with $\theta$. We require $f_{L \theta}>0$ to fit the data, and thus cannot separately identify $f_{L L}$ and $f_{L \theta}$ even with full knowledge of the labor supply curve $L$. Graphically this is analogous to saying that a given increase in wages and employment could be explained by a small upward shift in a relatively flat labor demand curve, or by a large upward shift in a relatively steep labor demand curve.

To examine quantitatively to what extent our results could be explained by a labor productivity shock, we next consider a Cobb-Douglas specification for production:

$$
f(L, \theta)=A K(\theta)^{\alpha_{K}} L^{\alpha_{L}}
$$

Here production uses labor and capital (with land held constant, and thus suppressed for notational simplicity), and we suppose that improvements in NREGS implementation $\theta$ also serve to augment the capital stock. This captures for example the possibility that increased NREGS activity leads to the creation of additional public assets such as roads and irrigation facilities which then increase labor productivity in the private sector. Using this specification, equating the marginal product of labor with the wage, and taking percentage changes, we can express the change in the capital stock required to explain a given change in wages and employment as

$$
\% \Delta K(\theta)=\frac{1}{\alpha_{K}}\left(\% \Delta w+\left(1-\alpha_{L}\right) \% \Delta L\right)
$$


Using factor share estimates of $\alpha_{L}=0.35$ and $\alpha_{K}=0.35$ from NSS 2012 cost of cultivation survey 63 (the remaining 0.3 is the factor share of land) and our observed AdjTE values for June of $\% \Delta L=17.8 \%$ and $\% \Delta w=10.2 \%$ (Table 2), the implication is that we would need an increase in the capital stock of $\% \Delta K=59.9 \%$ to fully explain our results 6465

To benchmark this figure, we consider what increase we might expect to see in the size of overall capital stock if the rate of NREGS asset creation increased in proportion to the increase in NREGS employment, or by $28.9 \%$ (Table 2). We estimate the size of the NREGS-generated capital stock as a proportion of the total stock of rural capital as follows. We obtain data on Gross Capital Formation in Agriculture and Allied sectors according to National Accounts data over the years 2002-03 through 201112 , and apply a depreciation rate of $10 \%$ per year to the stock to obtain a total capital stock of Rs. 6.48 trillion (in 2004-05 prices) ${ }^{66}$ In comparison, total NREGS expenditure in the years of the experiment (2010-11 and 2011-12) was Rs. 0.47 trillion (in 2004-05 prices).67 Assuming generously that $60 \%$ of this expenditure went directly to gross capital formation, this would result in 2010-12 NREGS-driven capital formation being $4.4 \%$ of all capital stock. This in turn yields $\% \Delta K=28.9 \% \times 4.4 \% \simeq 1.3 \%$, or around $2.4 \%$ of the increase that would be required to explain the joint increase in wages and employment we observe. This suggests that the creation of public assets likely played at most a marginal role in generating the labor market effects we observe.

\section{G.2.2 Imperfect competition}

Now consider a setting in which wage-setting is centralized to some degree by profit-maximizing employers. For analytical simplicity and transparency we consider fully centralized wage-setting (i.e. a monopsonist who sets wages to maximize profit as given by (11) ) and then discuss how the analysis relates to the case of oligopsony. We first show analytically that both wages and employment are increasing in the NREGS wage in the limit case where NREGS and private sector jobs are perfect substitutes, despite the fact that in this case equilibrium NREGS employment is zero. We then examine the case in which they are imperfect substitutes, showing numerically that we can obtain approximately the same result (i.e. substantial impacts on wages even when equilibrium NREGS employment is low). We also show that, as in the case of perfect competition, our data do not identify the marginal product of labor.

To build intuition, consider first the limit case in which NREGS jobs and private sector jobs are perfect substitutes. In this case there is an "effective" NREGS wage $e(\theta)$ such that for $w \geq e(\theta)$ no workers choose to work on the NREGS, while for $w<e(\theta)$ no workers choose to work in the private sector 68 The reservation wage will thus equal $e(\theta)$ for workers with relatively unattractive self-employment options, and equal the value $\tilde{r}(i)$ of self-employment for the rest. Denoting by $i^{c}$ the worker who is just indifferent

\footnotetext{
${ }^{63}$ The NSS cost of cultivation survey for 2011-12 was accessed from https://eands.dacnet.nic.in/Cost_of_ Cultivation.htm. The labor, capital and land factor shares for cultivating paddy in Andhra Pradesh were calculated using the item wise break up of cost of cultivation.

${ }^{64}$ Factor share calculations may underestimate labor shares if they miss labor income of the self-employed; in that case our calculations here would under-estimate the required increase in the capital stock.

${ }^{65}$ If instead we ignore spillovers and use the estimated main effects of treatment, we obtain a required increase in the capital stock of $\% \Delta K=37.0 \%$, smaller but still improbably large.

${ }^{66}$ See http://planningcommission.nic.in/data/datatable/data_2312/DatabookDec2014\%2043.pdf.

${ }^{67}$ Data from Sukhtankar (2017). Note that we count only the experimental years, since anything before those years would be equal in treatment and control areas.

${ }^{68}$ We assume ties are broken in favor of the private sector.
} 
between wage work and self-employment (i.e. $e(\theta)=\tilde{r}\left(i^{c}\right)$ ), we have

$$
r(i, \theta)= \begin{cases}e(\theta) & i \leq i^{c} \\ \tilde{r}(i) & i>i^{c}\end{cases}
$$

In this case the NREGS acts "as if" it set a binding minimum wage: employers cannot hire any positive quantity of labor at a wage below $e(\theta)$. If the wage that solves (11) is higher than $e(\theta)$ then this constraint does not bind and changes to the NREGS wage have no effect. If alternatively $e(\theta)$ is higher than the monopsonist's preferred wage then he sets $w=e(\theta)$; in this case increases in $\theta$ unambiguously increase both wages and employment until wages reach their competitive level.

Notably, improvements to the NREGS can have substantial impacts on private sector wages and employment in this case even when equilibrium levels of NREGS employment are zero. This result is of course too stark to map exactly to our data, where we observe positive employment levels in both the NREGS and the private sector. It illustrates the point, however, that the mechanism through which improving the NREGS affects the private sector can work through its role as an outside option, rather than through NREGS employment levels per se.

Now consider the less stark case in which NREGS jobs and private sector jobs are imperfect substitutes. Labor supply $L(w, \theta)=i^{*}(w, \theta)$ is a smooth, differentiable function, increasing in $w$ and decreasing in $\theta$. The monopsonist's profit-maximizing wage satisfies

$$
\frac{w}{f_{L}}=\frac{\epsilon}{\epsilon+1}
$$

This relates the markdown (relative to marginal product) that the monopsonist is able to extract from workers, a measure of his labor market power, to the elasticity of supply. ${ }^{69}$ As usual, effective market power on one side of the market is decreasing in the price elasticity of participation by actors on the other side of the market.

This metric likely represents an upper bound on the market power of employers in our setting, where wage-setting need not be fully centralized. With multiple employers the profit-maximizing wage for a given employer is still characterized by Equation (18) but with $\epsilon$ defined as the elasticity of labor supply facing that specific employer. Since employer-specific elasticities must be greater than the aggregate elasticity, the (inverse of the) aggregate elasticity provides an upper bound on the market power of any individual employer. Numerically, using our estimate of $\epsilon=3.07$ above, this implies a lower bound of $75 \%$ on the share of marginal product that any individual employer pays its workers. By way of comparison, a review by Sokolova and Sorensen (2021) of studies across a wide range of labor markets finds an average elasticity among studies following "best practices" of 7.1, implying that workers receive $88 \%$ of their marginal product, with a $95 \%$ confidence interval from $64 \%$ to $93 \%$. Our point estimate lies towards the lower end of this range, meaning that our results are consistent with a substantial degree of employer market power relative to what other studies have found.

\footnotetext{
${ }^{69}$ Note that the monopsonist does not choose to ration jobs. If more workers wanted to work for him at the offered wage than he wanted to hire, he could increase profits by (for example) lowering his wage offer while holding employment levels fixed. Rationing could emerge as a result of market power among workers, on the other hand, as for example in the case of a labor union that negotiates a wage above the market-clearing one.
} 
Taking comparative statics with respect to NREGS quality $\theta$ yields

$$
\begin{aligned}
& \frac{d w}{d \theta}=\frac{L_{\theta}-L_{w} f_{L \theta}-f_{L L} L_{\theta} L_{w}-L_{w \theta}\left(f_{L}-w\right)}{L_{w}^{2} f_{L L}+L_{w w}\left(f_{L}-w\right)-2 L_{w}} \\
& \frac{d L}{d \theta}=\frac{-f_{L \theta} L_{w}^{2}+L_{\theta}\left(L_{w w}\left(f_{L}-w\right)-L_{w}\right)-L_{\theta w} L_{w}\left(f_{L}-w\right)}{L_{w}^{2} f_{L L}+L_{w w}\left(f_{L}-w\right)-2 L_{w}}
\end{aligned}
$$

The former expression implies that, under believable distributional assumptions, wages should increase. The (common) denominator in these expressions is the second-order condition for the monopsonist's problem and is thus negative at an optimum. The numerator in the wage expression is also negative provided that $f_{L \theta}$ and $L_{w \theta}$ are not too negative. The first condition holds assuming that any productivity spillovers from an improved NREGS are positive, while the second holds if the labor supply curve facing the firm does not become too much steeper (which is what one would expect if an improved NREGS has a larger effect on the reservation wages of lower-wage workers).

The sign of the effect on employment is ambiguous, as expected. The denominator is again negative (assuming $L_{w w}<0$, consistent with the distribution of wages and reservation wages we observe in the data). The numerator then includes the following effects: (i) the direct effect of any improvements in the NREGS on the marginal productivity of labor, which tends to increase employment (represented by $f_{L \theta}>0$ in the first term); (ii) the upward shift in the labor supply curve, which per se tends to reduce employment (represented by $L_{\theta}<0$ in the second term); and (iii) the change in the elasticity of labor supply (due to $L_{w \theta}$ in the third term) which may increase or decrease the level of employment the firm chooses depending on its sign. Note in particular that if $L_{w \theta}$ is sufficiently large and the firm enjoys substantial market power $\left(f_{L}-w>0\right)$, then the overall effect will be positive even if $f_{L \theta}=0$, i.e. we do not need to assume productivity spillovers from the NREGS in order to generate a pattern of rising wages and employment.

Given this ambiguity, we next demonstrate via numerical example that both wages and employment may increase with NREGS quality, and that these effects can be substantial even when equilibrium NREGS employment is low. Figure G.1 visualizes an example that illustrates these points. Panel (a) plots labor supply curves and equilibrium wage / employment pairs for an increasing series of values of $\theta$, illustrating the concurrent increase in wages and employment. Panel (b) plots the share of the population employed in the two sectors at equilibrium for different $\theta$. We see that the increase in employment in private sector is observed even when the proportion of the population employed in NREGS is very low.

The wage elasticity of labor demand, in the sense of the response of labor demand to exogenous change in wages, is not defined in this case since wages are chosen endogenously by the monopsonist. That said, we can still examine whether the quantity $\epsilon^{D}=\frac{w}{L} \frac{1}{f_{L L}}$ is identified. As above, our data allow us to estimate the ratio

$$
\frac{d w / d \theta}{d L / d \theta}=\frac{L_{\theta}-L_{w} f_{L \theta}-f_{L L} L_{\theta} L_{w}-L_{w \theta}\left(f_{L}-w\right)}{-f_{L \theta} L_{w}^{2}+\left(L_{\theta} L_{w w}-L_{w} L_{\theta w}\right)\left(f_{L}-w\right)-L_{\theta} L_{w}}
$$

Here we face the same issue as in the competitive case, as if $f_{L \theta} \neq 0$ we cannot separately identify $f_{L \theta}$ and $f_{L L}$. Even assuming $f_{L \theta}=0$, however, we would face the deeper issue that without firm-level data we cannot separately identify $f$ and the degree of imperfect competition among employers (which we have assumed here to be monopsonistic for illustrative purposes). Our data are thus consistent with a range of possibilities. 


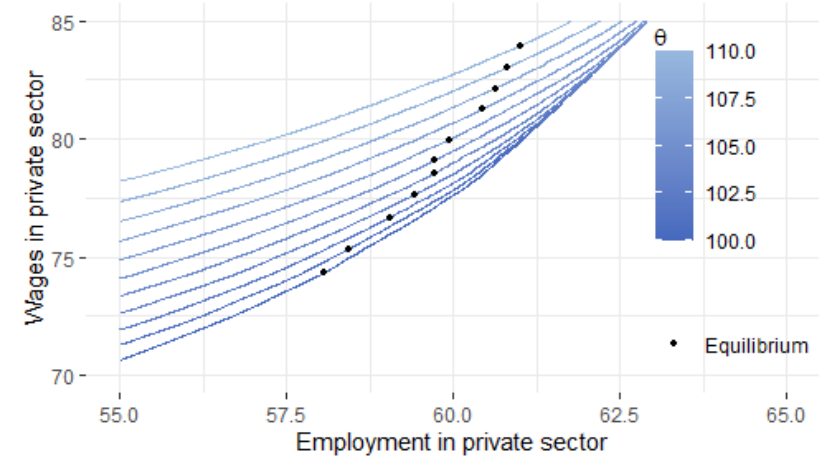

(a)

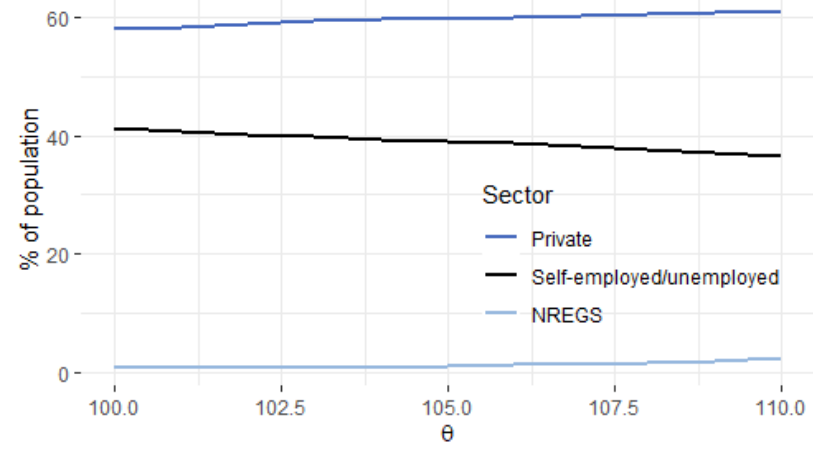

(b)

Figure G.1: Labor market equilibria under imperfect competition

This figure presents a simulation to show how it is possible for both wages and employment to increase in response to an improvement in the quality of NREGS jobs (and the value of NREGS as an outside option). Figure (a) illustrates labor supply curves and equilibrium employment / wage pairs $(L, w)$ under the assumption of monopsony wage-setting. Figure (b) shows the proportion of the population employed in the two sectors at equilibrium under monopsony wage setting for different values of $\theta$. In this simulation, the reservation wage for 160,000 workers for NREGS work is uniformly distributed between 50 and 150 and for the private sector work is equal to $\exp \left(\right.$ Reservation wage $\left._{\mathrm{NREGS}}+20\right) / 30+\mathrm{a}$ random Uniform[-20,20] noise. The firm's production function is $2500 \sqrt{L}$.

\section{G.3 Returns to land}

We now turn to examining how NREGS quality affects the returns to land. To do so we augment the production function in (15) to make explicit the roles of capital and land. The profit earned by the firm is then:

$$
\Pi=A K(\theta)^{\alpha_{K}} L^{\alpha_{L}} T^{\alpha_{M}}-r K-w L-p M
$$

where $T$ represents land and $p$ is the rental value of land.

In this section we derive the comparative statics of $p$, the rental value of land. We examine the effect on $p$ of varying $\theta$ under the same two assumptions of wages equal marginal product of labor, as under perfect competition, and that wages are set as if set by a single, monopsonistic employer. In each case, we compute the treatment effect on returns to land under the model from the improvement in the NREGS work quality $\theta$ given the impact on wages and labor supply.

\section{G.3.1 Perfect competition}

In this case the firm demands labor, capital, and land to maximize profit given wage and prices. We assume the capital stock and land owned is not affected by the change in NREGS program quality $\left(K^{\prime}(\theta)=0\right)$ in the short run, implying that labor is easiest factor of production to adjust in the short run. This implies the following relationship between the short term returns to land $(p)$ and the exogenous wage:

$$
\frac{d \log p}{d \theta}=\frac{\alpha_{L}}{\alpha_{L}-1} \frac{d \log w}{d \theta}
$$

We calculate the labor share $\alpha_{L}$ to equal 0.35 from NSS 2012 cost of cultivation survey. The treatment effect on equilibrium wage is $10.2 \%$. This implies a $5.5 \%$ decline in the returns to land due to the treatment. 


\section{G.3.2 Imperfect competition}

We now consider a market where a single firm is a monopsonistic employer and decides equilibrium wage and labor demand endogenously given the workers' labor supply curve. We assume the firm has the same Cobb-Douglas production function. As before, we assume the capital stock and land owned are fixed in the short run. The firm hence choose wage and labor supplied given the capital stock, land, and the workers' labor supply curve.

By the envelope theorem, the change in the labor supply due to change in $\theta$ and the change in wage due to change in labor do not have a first order effect on the profit or the returns to land. The returns to land is impacted only by the direct change in wage due to the change in $\theta$. We derive the following relationship for the impact on short term returns to land:

$$
\frac{d \log p}{d \theta}=\frac{\alpha_{L}}{\alpha_{L}-\text { markdown }} \frac{\partial \log w(L, \theta)}{\partial \theta}
$$

where markdown is the ratio of marginal product of labor and wage. We estimate labor elasticity of 3.07 which implies a wage markdown of 1.33 . The last term in the expression is the treatment effect on the labor supply curve for a fixed labor supply. We estimate this using the treatment effect on the reservation wage as $7.1 \%$. Assuming $\alpha_{L}=0.35$, this yields a $2.5 \%$ decline in the returns to land due to the treatment. 


\section{H Distributional analysis}

This appendix outlines the procedures used to arrive at the distributional analysis presented in Figure 2 and the supplementary visualization (Figure H.1) in this appendix. Using both our original survey data and model-based calculations, we are able to estimate the treatment effects on wage income and profits-per-acre across the distribution of landholdings for every household in the SECC roster. Our findings are robust to various treatment estimates and measurement techniques.

\section{H.1 Discrete landholding intervals}

Using the SECC household-level data, we first sort households by landholdings, then collapse them into discrete bins based on landoldings. Panels A-C of Figure 2 are all ordered in ascending order of household land holdings (with the width of the bars indicating the fraction of the population at that level of landholding). Panel A presents the estimated impacts on wage income, Panel B presents the estimated impacts on profits, and Panel $\mathrm{C}$ adds the two to present estimated net income gains.

To calculate effects on labor earnings (Panel A), we first calculate the labor endowment of each household in the SECC as the number of adults aged 18-65 in the household. We then construct the average of this number across households in each bin of landholdings, indicated by the black line (scale on the right-hand y-axis). We then multiply this by the adjusted treatment effect on earnings from wage labor per adult aged 18-65 in our survey (Table H.1) to obtain the estimated effect on labor earnings (blue bars, left-hand scale). The adjustment for number of working adults accounts for the variation in households' endowment of working-age adults. For instance, some very poor households by landholding may also not have working adults (e.g. in cases where household members are elderly), and may hence not be able to benefit from increased wages and labor income.

For profits (Panel B), we first calculate mean land-holdings in the SECC data in each bin (black line, right-hand scale). We then multiply these by two different estimates of effects on profits-peracre, indicated by the two different colored bars in Panels B (and C). The first (blue bar) uses the treatment effects on land profits estimated in our survey data, indicating a $6.2 \%$ decrease in value-peracre (Column 5 of Table 3). The second (grey bar), uses the estimated effect under a Cobb-Douglas Production Function and imperfectly competitive labor markets (see Appendix G.3.2), indicating a 2.5\% decrease in profits. To convert this percentage reduction in land profits to a rupee value, we multiply by the estimated mean profits per acre of land in Andhra Pradesh of $\sim$ Rs. 10,200 using the 2012 NSS Cost of Cultivation Survey 70

The third panel shows the sum of estimated treatment effects on wages (Panel A) and profits (Panel B) treatment effects. Our default estimate of profit reduction (based on the $6 \%$ decrease in land value estimated in our survey data), suggests that all households with landholdings below 7 acres were made better off 71 The second model-based estimate under imperfect competition (which yields a profit reduction of 2.5\%) suggests that households further up the landholding distribution also saw income gains. In the second case, net income is only negative for households holding more than 24 acres of land, who comprise only $0.77 \%$ of the population.

\footnotetext{
${ }^{70}$ See http://mospi.nic.in/sites/default/files/publication_reports/KI_70_33_19dec14.pdf. The Cost of Cultivation survey provides estimates of net receipt from cultivation at the state level. We take this monthly estimate of Rs. 2,022 for Andhra Pradesh (from Table 7 on page A-11 of the report above), multiply it by 12 to get the yearly estimate, and then divide by the average landholding for agricultural households in AP recorded in the same survey (2.39 acres). This gives us an yearly profit-per-acre estimate of Rs. 10,164, which we round up to 10,200.

${ }^{71}$ The net-impact is close to zero for the group holding between 5.1-10 acres of land as shown in 2. This is the average of modest positive net impacts below 7 acres and negative net impacts over 7 acres.
} 
These results are robust to alternative rupee estimates of profits-per-acre. For instance, Foster and Rosenzweig (2011) estimate a considerably lower mean profit-per-acre of Rs. 1500 (after imputing for the cost of own labor) compared to the Rs. 10,200/acre we use from the NSS. In this case, the rupee value of the profit reduction would be significantly lower, and we would estimate positive net effects for nearly all households.

\section{H.2 Continuous measure of socioeconomic status}

As an alternative way to visualize distributional effects, we also run a similar procedure as above using a more comprehensive measure of socioeconomic status to order households and present the result in Figure H.1. The SECC does not have a continuous measure of income since it only categorizes households into 3 income categories based on whether the highest-earning member of the household has monthly earnings below Rs. 5,000, between Rs. 5,000 and 10,000, or above Rs. 10,000. To obtain a continuous measure of income in the SECC, we run a logistic regression of a binary measure of income (whether the household is in or out of the lowest category above, which accounts for $83 \%$ of households in the control group) on several predictors of socioeconomic status (SES) including landholdings but also home ownership, the number of rooms in the home, whether the home is a pucca (brick/stone) home, an indicator for whether the household is scheduled caste or schedule tribe, education level, whether there is a member who has a disability, and a variable that is the first principal component of several asset variables. We then use the fitted values from this regression as a measure of each household's affluence or socioeconomic status (SES).

Grouping these values into percentiles, ranked from low (1) to high (100), we then plot the mean number of adults aged 18-65 in a given household (Panel A), and total landholdings in acres (Panel B) for each percentile of the SES distribution. Performing a Loess regression on the two plotted distributionsthat is, mean working-age adults and mean landholding by SES percentile-yields a smooth estimate of the distribution. We then apply our wage and profit treatment effects based on both our survey and model estimates (as described above) to these two smoothed distributions, and add the two values at each percentile of the distribution to arrive at the net treatment effect (Panel C).

We see that the overall narrative is quite similar to that presented in Figure2, with the main difference being that the net impact of the reform (in Figure H.1) now appears to be positive at all percentiles of the SES distribution - using both survey and model based estimates of profit reduction from land. The difference relative to Figure $\mathrm{H} .1$ is that this measure of SES includes several other variables in addition to landholdings. Thus, while landholdings are strongly positively correlated with SES, the mean landholdings for the highest SES are (understably) lower than when we sort households only by landholdings as we do in Figure 2. The reductions in profits are correspondingly lower. Correspondingly, the net gains lower in the SES distribution are less positive, because even low SES households do own at least some land (on average), and would therefore experience a reduction in land returns, though this is much less than the gain in wages. 
Table H.1: Earnings from wage labor per working-age adult

Wage per worker

(1)
Working-age adults

$(2)$

\begin{tabular}{lcc}
\hline Adjusted TE & $1946^{* * *}$ & .23 \\
$\left(\beta_{T}+0.36 * \beta_{N}\right)$ & $(729)$ & $(.21)$ \\
& $\{797\}$ & $\{.22\}$ \\
Main effect & $1630^{* * *}$ & .13 \\
$\left(\beta_{T}\right)$ & $(585)$ & $(.16)$ \\
& $\{612\}$ & $\{.17\}$ \\
Nbhd effect & 317 & .098 \\
$\left(0.36 * \beta_{N}\right)$ & $(307)$ & $(.1)$ \\
& $\{312\}$ & $\{.099\}$ \\
\hline Control mean & $7,525.0$ & 4.1 \\
Adjusted $R^{2}$ & .053 & .023 \\
Observations & 4,732 & 4,892 \\
\hline
\end{tabular}

The unit of analysis is a household. In Column 1, we take working-age adults to be those aged between 18 and 65 . We divide the household-level wage labor income (both physical labor income and income from NREGS) by the number of working-age adults per household. Column 2 presents a balance test of the mean number of working-age adults per household across treatment and control groups. Standard errors in parentheses are clustered by mandal; those in brackets are spatial as in Conley (2008). Significance based on the former is denoted: ${ }^{*} p<.10,{ }^{* *} p<.05,{ }^{* * *} p<.01$. 
Figure H.1: Wage and profit estimates across imputed consumption percentiles

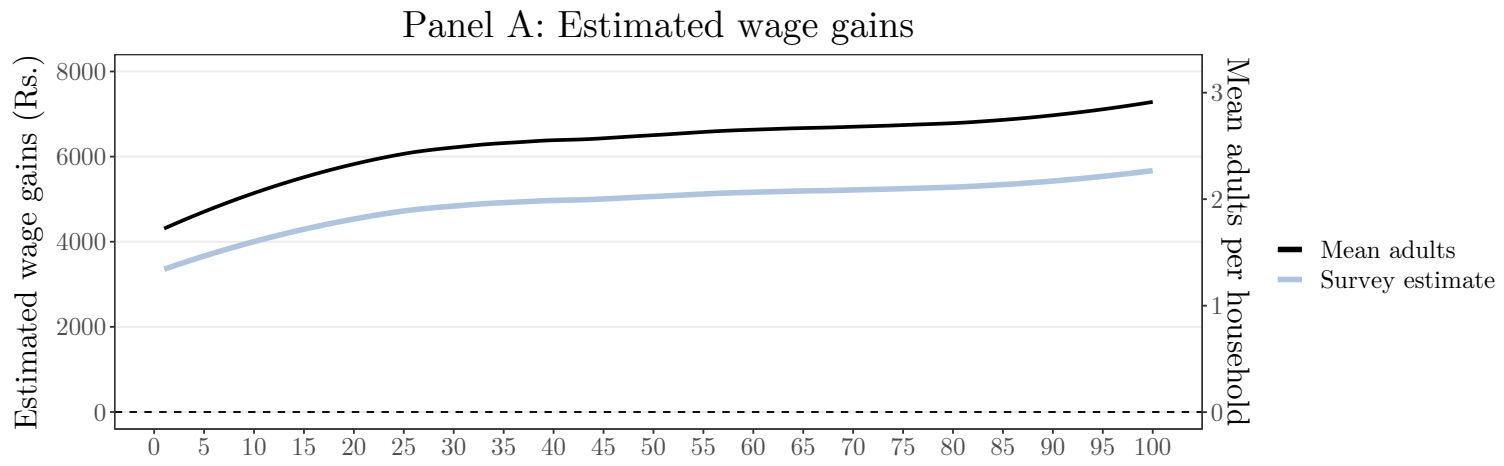

Panel B: Estimated profit reduction
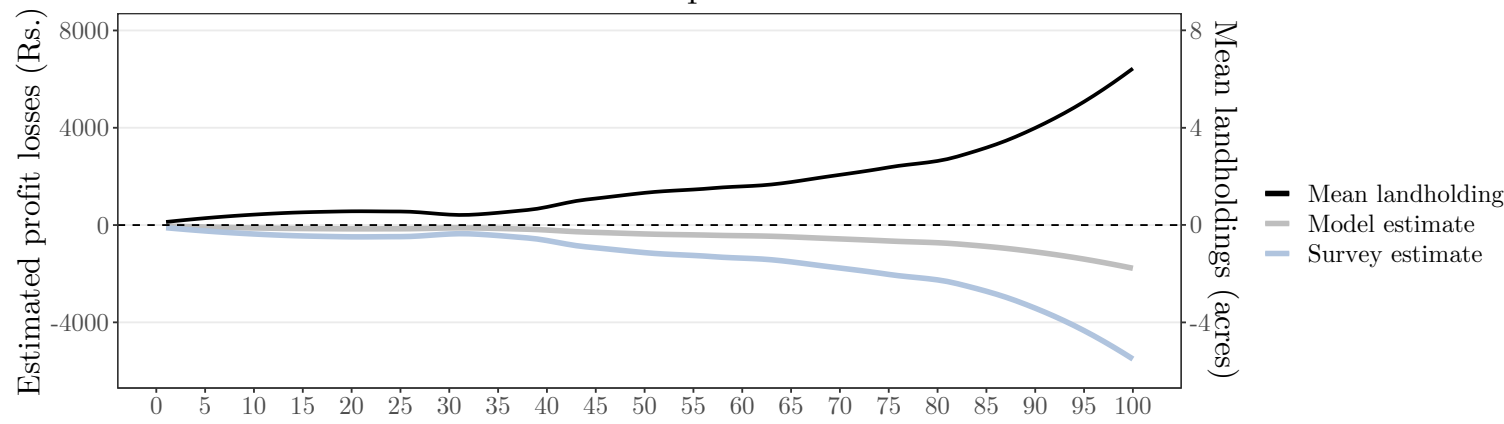

Panel C: Net impact

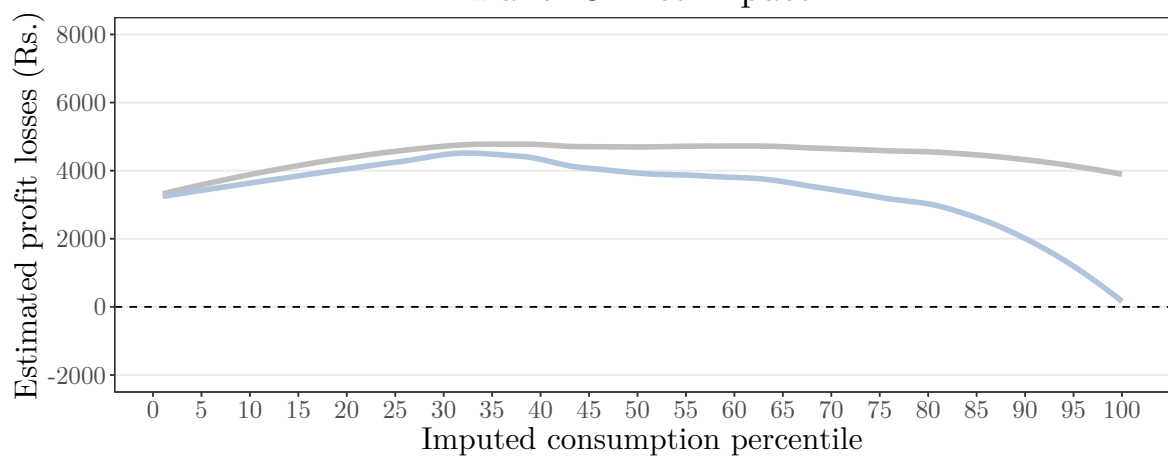

- Model estimate

- Survey estimate

Panel A shows the fraction of working-age adults (aged 18-65) per household for each consumption percentile (black line, right-hand axis). The blue lines and left-hand axis show the estimated wage gains when we apply the treatment effect estimated in our survey data to the distribution of adults. Panel B shows both the mean landholding size in acres for each percentile plus two estimates of profit losses (derived from our survey estimates and model-based estimates). Panel 3 shows the net impact, calculated by summing the estimated wage gains with the two estimated profit losses. We describe our estimation strategy above. 


\section{Naive ITT estimates}

This appendix provides Naive ITT estimates for each of the survey estimates in the main exhibits section.

Table I.1: Earnings (ITT)

\begin{tabular}{|c|c|c|c|c|c|}
\hline & Total & NREGA & Wage labor & $\begin{array}{c}\text { Self } \\
\text { employment }\end{array}$ & Misc. \\
\hline & (1) & $(2)$ & (3) & $(4)$ & $(5)$ \\
\hline Naive ITT & $\begin{array}{l}8789^{* *} \\
(3713)\end{array}$ & $\begin{array}{c}914 \\
(588)\end{array}$ & $\begin{array}{c}6546^{* * * *} \\
(2056)\end{array}$ & $\begin{array}{l}1523 \\
(2709)\end{array}$ & $\begin{array}{c}528 \\
(2103)\end{array}$ \\
\hline Baseline & Yes & No & No & No & No \\
\hline Control mean & 69122.1 & 4743.4 & 24120.2 & 26563.1 & 13695.4 \\
\hline Adjusted $R^{2}$ & .0402 & .0148 & .0538 & .0161 & .0122 \\
\hline Observations & 4874 & 4907 & 4908 & 4908 & 4908 \\
\hline
\end{tabular}

Refer to Table 1 for our main specification and variable descriptions.

Table I.2: Employment and wages in June (ITT)

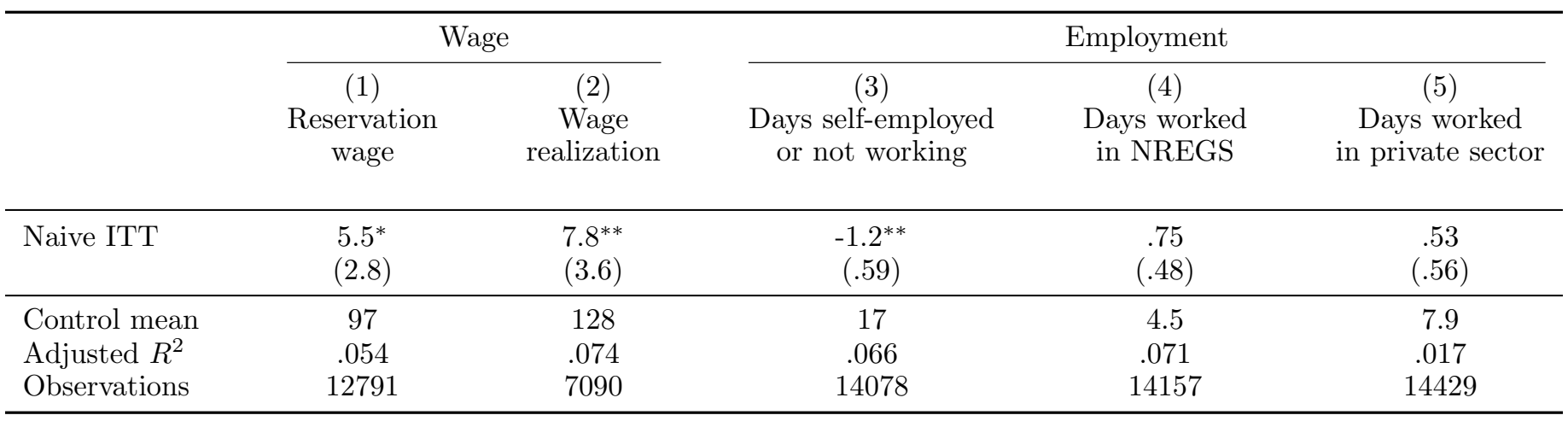

Refer to Table 2 for our main specification and variable descriptions. 
Table I.3: Prices (ITT)

\begin{tabular}{|c|c|c|c|c|c|}
\hline & \multicolumn{3}{|c|}{ Consumer goods } & \multicolumn{2}{|c|}{ Land } \\
\hline & (1) & $(2)$ & (3) & & (5) \\
\hline & Index: uniform goods & Index: all goods & Individual goods & $\begin{array}{l}\text { Own-land } \\
\text { profits }\end{array}$ & Value per acre \\
\hline Naive ITT & $\begin{array}{l}.0041 \\
(.066)\end{array}$ & $\begin{array}{l}.0048 \\
(.025)\end{array}$ & $\begin{array}{l}-.011 \\
(.011)\end{array}$ & $\begin{array}{l}-.077 \\
(.076)\end{array}$ & $\begin{array}{c}-.063 \\
(.1)\end{array}$ \\
\hline Item $\mathrm{FE}$ & No & No & Yes & No & No \\
\hline Unit of analysis & Village & Village & Item x Household & Household & Household \\
\hline Control mean & 11.12 & 10.69 & -3.088 & 10.00 & 11.71 \\
\hline Adjusted $R^{2}$ & .981 & .998 & .952 & .257 & .173 \\
\hline Observations & 60 & 60 & 18242 & 2508 & 3075 \\
\hline
\end{tabular}

Refer to Table 3 for our main specification and variable descriptions.

Table I.4: SECC income categories (ITT)

\begin{tabular}{|c|c|c|c|c|}
\hline & $\begin{array}{c}\text { Lowest bracket } \\
(<\text { Rs. } 5,000)\end{array}$ & $\begin{array}{c}\text { Middle bracket } \\
\text { (Rs. } 5,000-10,000)\end{array}$ & $\begin{array}{l}\text { Highest bracket } \\
(>) \text { Rs. 10,000) }\end{array}$ & $\begin{array}{c}\text { Income bracket } \\
3 \text { levels }\end{array}$ \\
\hline & (1) & (2) & (3) & (4) \\
\hline Naive ITT & $\begin{array}{c}-.041^{* * *} \\
(.014)\end{array}$ & $\begin{array}{l}.026^{* *} \\
(.011)\end{array}$ & $\begin{array}{l}.014^{* *} \\
(.0065)\end{array}$ & $\begin{array}{c}-.041^{* * *} \\
(.014)\end{array}$ \\
\hline Control mean & .83 & .13 & .038 & \\
\hline Adjusted $R^{2}$ & .01 & .014 & .015 & .008 \\
\hline Observations & $1.8 \mathrm{M}$ & $1.8 \mathrm{M}$ & $1.8 \mathrm{M}$ & $1.8 \mathrm{M}$ \\
\hline
\end{tabular}

Refer to Table 4 for our main specification and variable descriptions. 
Table I.5: Non-agricultural enterprises and employees (ITT)

\begin{tabular}{|c|c|c|c|c|c|}
\hline & $\frac{\text { All sectors }}{(1)}$ & $\frac{\text { Livestock }}{(2)}$ & $\frac{\begin{array}{c}\text { Manufacturing } \\
\text { and construction }\end{array}}{(3)}$ & $\begin{array}{l}\text { Wholesale } \\
\text { and retail } \\
(4)\end{array}$ & $\frac{\text { Other }}{(5)}$ \\
\hline \multicolumn{6}{|c|}{ Panel A: Effect on number of employees } \\
\hline Naive ITT & $\begin{array}{c}2376^{* *} \\
(1132) \\
{[.21]}\end{array}$ & $\begin{array}{c}134 \\
(206) \\
{[.33]}\end{array}$ & $\begin{array}{l}626^{*} \\
(321) \\
{[.24]}\end{array}$ & $\begin{array}{l}773^{*} \\
(405) \\
{[.24]}\end{array}$ & $\begin{array}{l}843^{*} \\
(449) \\
{[.23]}\end{array}$ \\
\hline $\begin{array}{l}\text { Control mean } \\
\text { Adjusted } R^{2} \\
\text { Observations }\end{array}$ & $\begin{array}{c}6796.7 \\
0.17 \\
157\end{array}$ & $\begin{array}{c}1711.5 \\
0.52 \\
157\end{array}$ & $\begin{array}{c}1439.9 \\
0.17 \\
157\end{array}$ & $\begin{array}{c}1219.2 \\
0.12 \\
157\end{array}$ & $\begin{array}{c}2426.1 \\
0.12 \\
157\end{array}$ \\
\hline \multicolumn{6}{|c|}{ Panel B: Effect on number of enterprises } \\
\hline Naive ITT & $\begin{array}{l}884^{* *} \\
(434) \\
{[.17]}\end{array}$ & $\begin{array}{l}76 \\
(121) \\
{[.33]}\end{array}$ & $\begin{array}{l}215 \\
(140) \\
{[.25]}\end{array}$ & $\begin{array}{c}313^{*} \\
(168) \\
{[.2]}\end{array}$ & $\begin{array}{l}280^{*} \\
(166) \\
{[.21]}\end{array}$ \\
\hline $\begin{array}{l}\text { Control mean } \\
\text { Adjusted } R^{2} \\
\text { Observations }\end{array}$ & $\begin{array}{c}3816.5 \\
0.29 \\
157\end{array}$ & $\begin{array}{c}1127.3 \\
0.58 \\
157\end{array}$ & $\begin{array}{l}754.1 \\
0.22 \\
157\end{array}$ & $\begin{array}{c}739.3 \\
0.17 \\
157\end{array}$ & $\begin{array}{c}1195.7 \\
0.25 \\
157\end{array}$ \\
\hline
\end{tabular}

Refer to Table 5 for our main specification and variable descriptions.

Table I.6: Assets, liabilities, and expenditure (ITT)

\begin{tabular}{|c|c|c|c|c|c|}
\hline & \multirow{2}{*}{$\begin{array}{c}\text { Total savings } \\
\text { (Rs.) }\end{array}$} & \multirow{2}{*}{$\begin{array}{c}\begin{array}{c}\text { Total loans } \\
\text { (Rs.) }\end{array} \\
(2)\end{array}$} & \multirow{2}{*}{$\begin{array}{c}\text { Owns land } \\
\frac{(\%)}{(3)}\end{array}$} & \multicolumn{2}{|c|}{$\begin{array}{l}\text { Annualized expenditure } \\
\text { (Rs. per year) }\end{array}$} \\
\hline & & & & (4) & $(5)$ \\
\hline Naive ITT & $\begin{array}{l}-21 \\
(280)\end{array}$ & $\begin{array}{l}8931^{*} \\
(4791)\end{array}$ & $\begin{array}{l}.049^{* *} \\
(.024)\end{array}$ & $\begin{array}{l}-974 \\
(3992)\end{array}$ & $\begin{array}{l}15512^{*} \\
(8704)\end{array}$ \\
\hline Control mean & 2966 & 68108 & .59 & 85031 & 58779 \\
\hline Survey & NREGA & NREGA & NREGA & NREGA & NSS \\
\hline Adjusted $R^{2}$ & .017 & .0099 & .032 & .014 & .084 \\
\hline Observations & 4858 & 4891 & 4887 & 4878 & 223 \\
\hline
\end{tabular}

Refer to Table 7 for our main specification and variable descriptions. 


\section{J Comparison to Imbert and Papp (2015)}

In this section, we show that the difference between our estimated average earnings gains $(10.9 \%$ of mean PCE) and IP's is fully explained by the differences in our estimated employment effects. That is, we show that if we adjust our estimated earnings impacts to reflect (i) the all-India percentage increase in wages that IP find $(4.7 \%)$, and (ii) the elasticity of demand they estimate (-0.38), we obtain an increase equal to $3.3 \%$ of mean PCE, within the range of the earnings gains they report by quintile. We do so by adjusting the impacts on earnings from the NREGS, from wage labor, and from other sources as reported in Table 1 as follows:

- NREGS. We (conservatively) leave these unchanged, at Rs. 1,295.

- Wage labor. We scale these down by the ratio

$$
\frac{\left(1+\% \Delta w^{I P}\right) \times\left(1+\% \Delta e^{I P}\right)-1}{\left(1+\% \Delta w^{M N S}\right) \times\left(1+\% \Delta e^{M N S}\right)-1}
$$

i.e. the ratio of the percentage change in labor earnings we would expect to see given the wage increase in IP $\left(\% \Delta w^{I P}=4.7 \%\right)$ and the corresponding employment change $\left(\% \Delta e^{I P}=4.7 \% \times-0.38\right)$ and that we would expect to see given the corresponding estimates in our own data $\left(\% \Delta w^{M N S}=\right.$ $9.4 \%, \% \Delta e^{M N S}=17.7 \%$ ). This yields a counterfactual effect of Rs. $7,607 \times 10 \%=$ Rs. 749 .

- Other sources. We scale these down as above, but (conservatively) omit the employment terms, as this category primarily reflects self-employment. This yields a counterfactual effect of Rs. 1,733× $(4.7 \% / 9.4 \%)=$ Rs. 844 .

This leaves us with a total counterfactual income gain of Rs. $1,295+$ Rs. $749+$ Rs. $844=$ Rs. 2,887 . Mean annual per capita expenditure in the NSS is Rs. 20,250; multiplied by the average household size in our data (4.31 individuals per household) yields total annual household expenditure of Rs. 20, $250 \times$ $4.31=$ Rs. 87, 277. The income gain relative to PCE is thus $2,887 / 87,277=3.3 \%$. 